\title{
Summary of Non-US National and International Fuel Cycle and Radioactive Waste Management Programs 1982
}

\author{
K. M. Harmon
}

J. A. Kelman

August 1982

Prepared for the U.S. Department of Energy under Contract DE-AC06-76RLO 1830

Pacific Northwest Laboratory Operated for the U.S. Department of Energy by Battelle Memorial Institute 


\title{
DISCLAIMER
}

This report was prepared as an account of work sponsored by an agency of the United States Government. Neither the United States Government nor any agency thereof, nor any of their employees, makes any warranty, express or implied, or assumes any legal liability or responsibility for the accuracy, completeness, or usefulness of any information, apparatus, product, or process disclosed, or represents that its use would not infringe privately owned rights. Reference herein to any specific commercial product, process, or service by trade name, trademark, manufacturer, or otherwise, does not necessarily constitute or imply its endorsement, recommendation, or favoring by the United States Government or any agency thereof. The views and opinions of authors expressed herein do not necessarily state cr reflect those of the United States Government or any agency thereof.

\author{
PACIFIC NORTHWEST L.ABORATORY \\ operated by \\ BATTELLE \\ for the \\ UNITED STATES DEPARTMENT OF ENERGY \\ under Contract DE-AC06-76RLO 1830
}

\begin{tabular}{|c|c|}
\hline \multicolumn{2}{|c|}{$\begin{array}{l}\text { National Technical Information Service } \\
\text { United States Department of Commerce } \\
5285 \text { Port Roval Road } \\
\text { Springfield, Virginia } 22151\end{array}$} \\
\hline \multicolumn{2}{|c|}{$\begin{array}{l}\text { NTIS Price Codies } \\
\text { Microfiche A01 }\end{array}$} \\
\hline \multicolumn{2}{|c|}{ Printed Copy } \\
\hline Pages & $\begin{array}{l}\text { Price } \\
\text { Codes }\end{array}$ \\
\hline $001-025$ & $\mathrm{~A} 02$ \\
\hline $026-050$ & $\mathrm{~A} 03$ \\
\hline $051-075$ & A04 \\
\hline $076-100$ & A05 \\
\hline $10:-125$ & A06 \\
\hline $126-150$ & $\mathrm{~A} 07$ \\
\hline $151-175$ & A08 \\
\hline $176-200$ & $\mathrm{~A} 09$ \\
\hline $201-225$ & A010 \\
\hline $226-250$ & $A 011$ \\
\hline $251-275$ & A012 \\
\hline $276-300$ & $\mathrm{~A} 013$ \\
\hline
\end{tabular}


PNL-4405

UC-70

SUMMARY OF NON-US NATIONAL

AND INTERNATIONAL FUEL CYCLE

AND RADIOACTIVE WASTE MANAGEMENT

PROGRAMS 1982
K. M. Harmon
J. A. Kelman

August 1982

Prepared for the U.S. Department of Energy under Contract DE-ACO6-76RLO 1830

Pac if ic Northwest Laboratory

Richland, Washington 99352 
CONTENTS

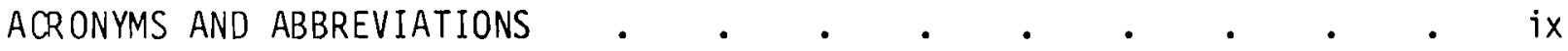

INTRODUCTION

NUCLEAR FUEL CYCLE AND WASTE MANAGEMENT ACTIVITIES $\quad . \quad$ • $\quad$ • 3

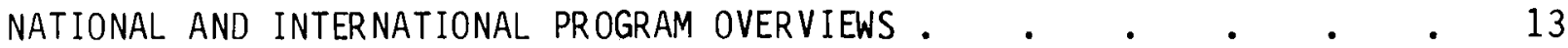

ARGENTINA .

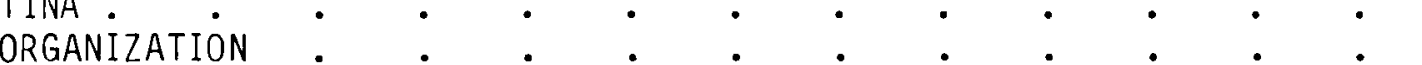

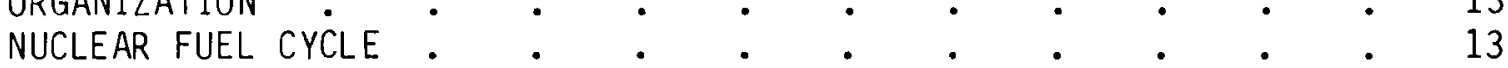

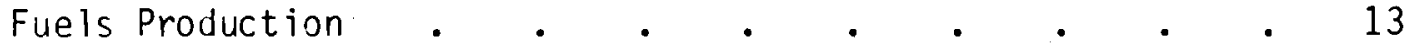

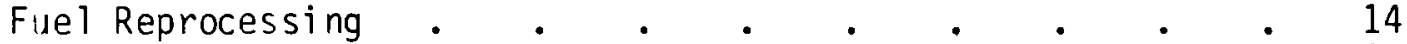

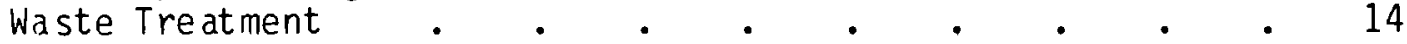

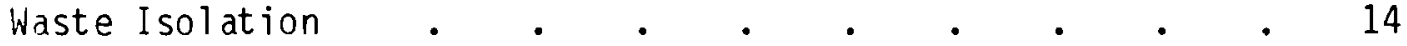

AUSTRALIA .

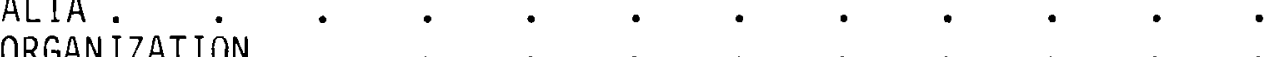

NUCLEAR FUEL CYCLE

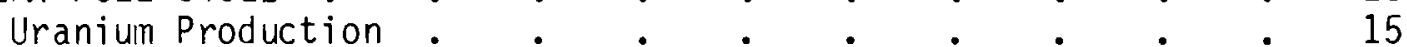

High-Level Waste Immobilization $. \quad . \quad . \quad . \quad . \quad . \quad 15$

Management of Mine and Mill Tailings . . . . . . 16

Geologic Waste Isolation. $. \quad . \quad . \quad . \quad . \quad . \quad . \quad 16$

AUSTRIA

ORGANIZATION

WASTE MANAGEMENT

BELGIUM

ORGANIZATION

NUCLEAR FUEL CYCLE

Fuels Production

Fuel Reprocessing

Waste Treatment

Waste Disposal.

Major Mi lestones

BRAZIL

ORGANIZATION

NUCLEAR FUEL CYCLE

CANADA

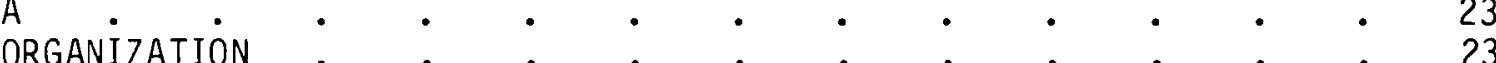

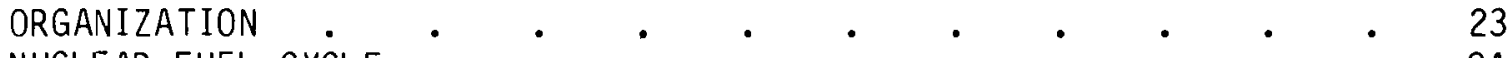

NUCLEAR FUEL CYCLE

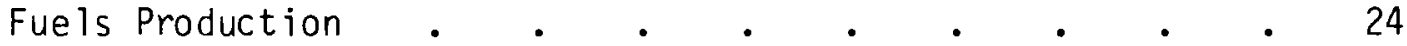

Spent Fuel Management . . . . . . . . . 25

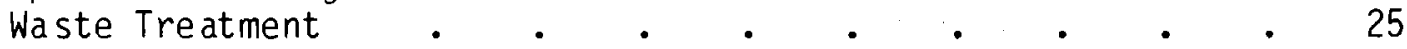

Disposal of Reactor and Other Low-Level Wastes . . . 26

Major Mi lestones 
CHINA (PEOPLE'S REPUBLIC) ORGANIZATION NUCLEAR FUEL CYCLE .

DENMARK

ORGANIZATION

WASTE MANAGEMENTं R\&D

F INLAND

ORGANIZATION

NUCLEAR FUEL CYCLE

WASTE MANAGEMENT

FRANCE

ORGANIZATION

NUCLEAR FUEL CYCLE

Fuels Production

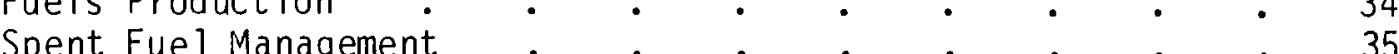

Waste Treatment $\cdot \cdot \cdot \cdot \cdot \cdot \cdot \cdot \cdot{ }^{*} \cdot{ }^{*} \cdot{ }^{\circ}$

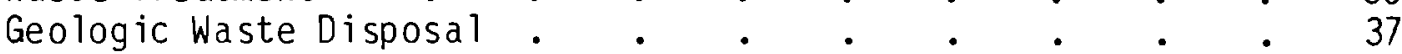

Major Mi lestones

GERMANY (FEDERAL REPUBLIC)

ORGANIZATION

Federal Agencies

Research Institutes.

Private Industry

NUCLEAR FUEL CYCLE

Fuels Production

Spent Fuel Management

Waste Treatment

HLW Vitrification

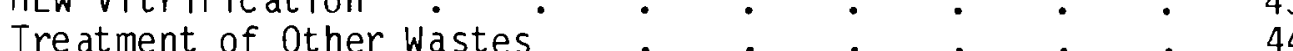

Waste Di sposal.

Major Mi lestones

INDIA

ORGANIZATION

NUCLEAR FUEL CYCLE

Fuels Production

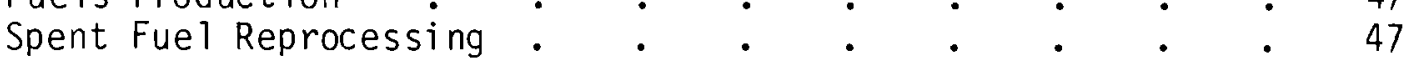

Waste Treatment

Waste Disposal.

I TALY

ORGAN IZATION

NUCLEAR FUEL CYCLE

Fuels Production

Spent Fuel Reprocessing 
Waste Treatment

Waste Disposal.

JAPAN
ORGAN IZATIÖ
Government Agencies
Industrial Organizations
NUCLEAR FUEL CYCLE
Fuels Production
Spent Fuel Management
Waste Management
Waste Treatment
Geologic Waste Di sposal
Major Mi lestones

KOREA (REPUBLIC OF KOREA) NUCLEAR POWER POL ICY ORGANIZATION

NUCLEAR FUEL CYCLE

Fuels Production

Spent Fuel Management

Waste Management

MEXICO

ORGAN IZATION

NUCLEAR FUEL CYCLE

THE NETHERLANDS

ORGANIZATION

NUCLEAR FUEL CYCLE

WASTE MANAGEMENT

PAK ISTAN

NUCLEAR FUEL CYCLE $\quad \cdot \quad \cdot \quad \cdot \quad \cdot \quad \cdot \quad \cdot \quad \cdot \quad \cdot \quad \cdot \quad \cdot \quad \cdot \quad \cdot \quad \cdot \quad \cdot 64$

SOUTH AFRICA

ORGAN IZATION

NUCLEAR FUEL CYCLE

SPAIN

ORGANIZATION

NUCLEAR FUEL CYCLE

Fuels Production

Fuel Cycle and Waste Management R\&D

SWEDEN

ORGANIZATION

NUCLEAR FUEL CYCLE

Fuels Production

Spent Fuel Management 
Waste Treatment

Spent Fuel and Waste Disposal.

Major Milestones

SWI TZERLAND

ORGANIZATION

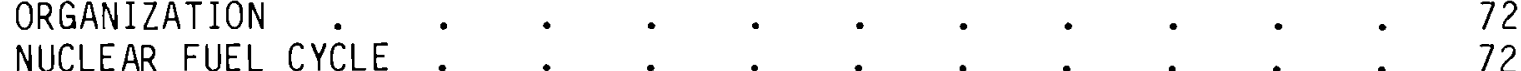

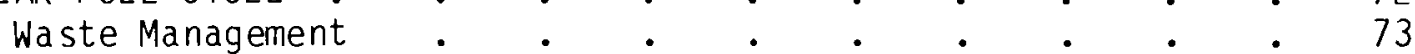

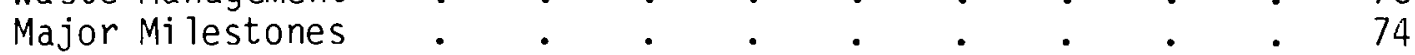

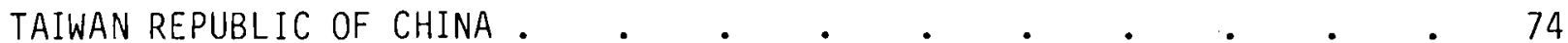

ORGANIZATION

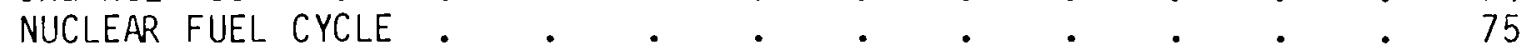

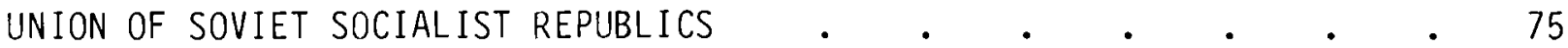

ORGANIZATION

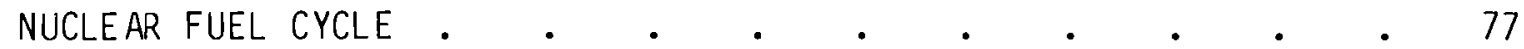

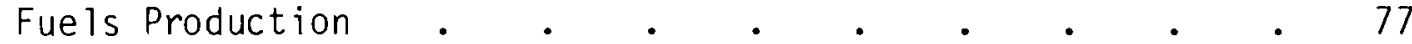

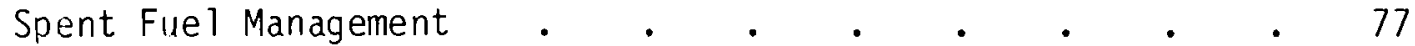

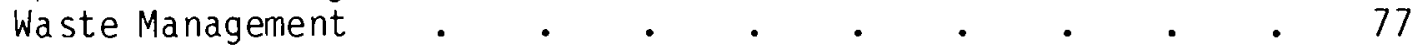

THE UNITED KINGDOM

ORGANIZATION

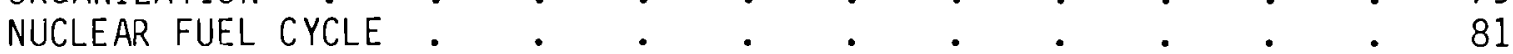

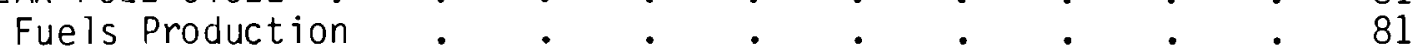

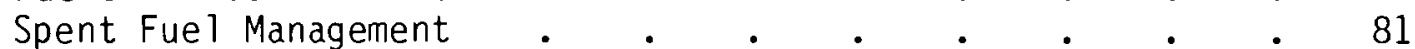

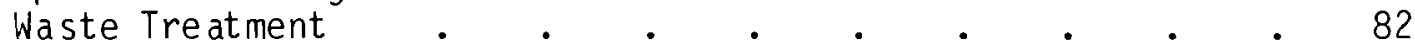

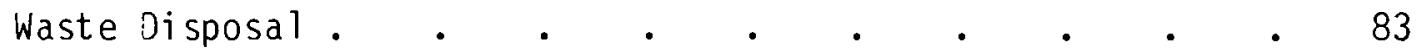

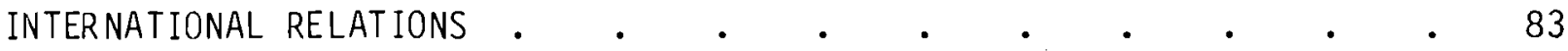

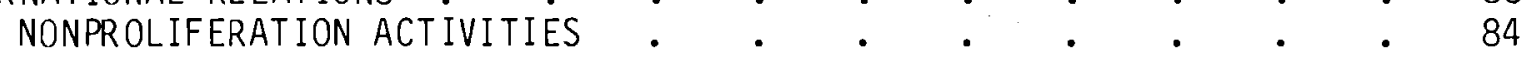

International Atomic Energy Agency Safeguards . $\quad . \quad$. 84

Treaty on Non-Prol if eration of Nuc lear Weapons $\quad . \quad$. $\quad . \quad 84$

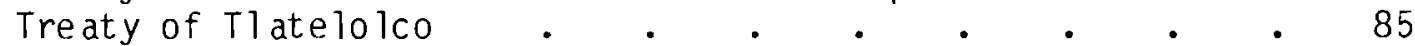

London Nuclear Suppliers' Group . $\quad . \quad$. $\quad . \quad$. 87

UNITED STATES' MULTILATERAL AGREEMENTS AND PROJECTS $\quad \cdot \quad \cdot \quad \cdot 88$

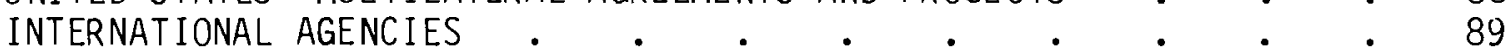

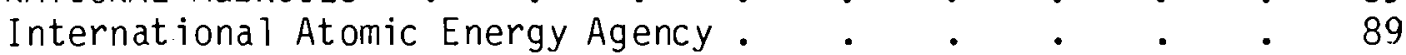

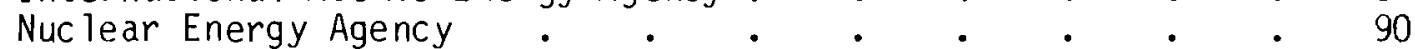

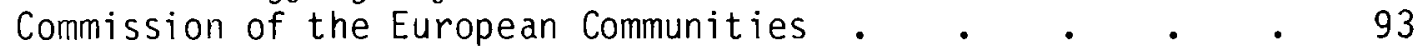

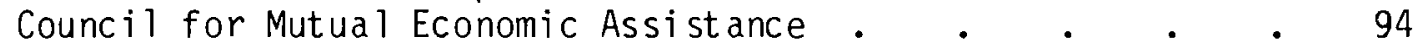

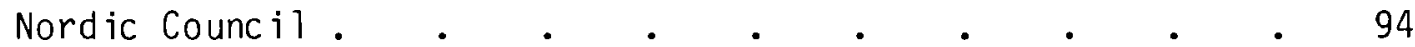

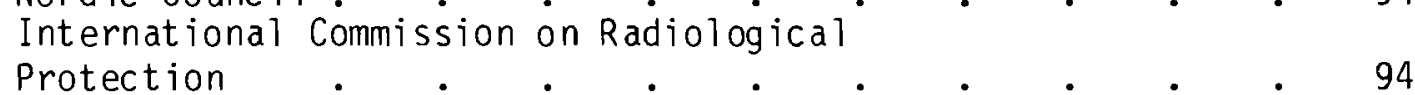

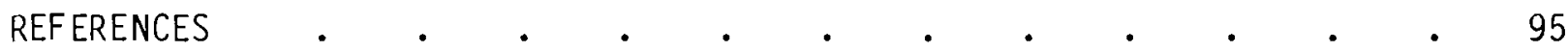




\section{$\underline{\text { TABLES }}$}

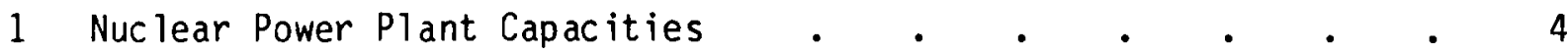

2 Fuel Cycle Strategy . . . . . . . . . . 6

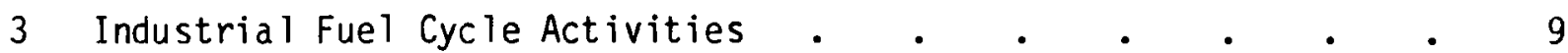

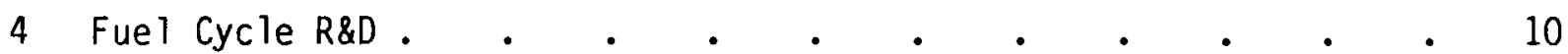

5 Waste Management R\&D . . . . . . . . . . 11

6 Non-Nuc lear-Weapon States Party to NPT $. \quad . \quad . \quad . \quad . \quad .86$ 

$\underline{\text { ACRONYMS }^{(a)} \text { AND ABBREVIATIONS }}$

$\begin{array}{ll}\text { AFR } & \text { Away-from-reactor } \\ \text { AVM } & \text { Waste vitrification plant at Marcoule, France } \\ \text { BWR } & \text { Boiling water reactor } \\ \text { CANDU } & \text { Canadian deuterium uranium reactor } \\ \text { FBR } & \text { Fast breeder reactor } \\ \text { FINGAL/HARVEST } & \text { British waste vitrification process } \\ \text { FIPS } & \text { West German process for vitrifying high-level waste, } \\ & \text { developed at Jülich } \\ \text { FRP } & \text { Fuel reprocessing plant } \\ \text { GCR } & \text { Gas-cooled reactor } \\ \text { GWe } & \text { 109 watts of electricity (1000 MWe) } \\ \text { HFR } & \text { High Flux Reactor at Petten, Netherlands } \\ \text { HLLW } & \text { High-level liquid waste } \\ \text { HLW } & \text { High-level waste } \\ \text { HTGR } & \text { High-temperature gas-cooled reactor } \\ H T R & \text { High-temperature reactor } \\ \text { HWLWR } & \text { Heavy water moderated, light water cooled reactor } \\ \text { HWR } & \text { (same as LWCHW) } \\ \text { LGR } & \text { Heavy water reactor } \\ \text { LLW } & \text { Light water cooled, graphite moderated reactor } \\ \text { LMFBR } & \text { Low-level waste } \\ \text { LWCHW } & \text { Liquid metal fast breeder reactor } \\ \text { LWR } & \text { Light water cooled, heavy water moderated reactor } \\ \text { MOX } & \text { (same as HWLWR) } \\ \text { Mtoe } & \text { Light water reactor } \\ \text { MTR } & \text { Mixed (plutonium-uranium) oxide } \\ & \text { Metric tons of oil equivalent } \\ \text { Materials test reactor }\end{array}$

(a) Acronyms for agencies, institutes, etc. are given in the Overview section for each country. 
PAMELA

PFR

PHWR

PWR

R\&D

tHM

THTR

TRU

tSWU

$\mathrm{tU}$

TWh

WAK
West German and Eurochemic process for converting highlevel waste to glass beads and embedding them in a metal alloy

Prototype Fast Reactor (UK)

Pressurized heavy water reactor

Pressurized water reactor

Research and development

Metric tons (tonnes) heavy metal

Thorium high-temperature reactor

Transuranic

Metric tons of separative work (uranium enrichment)

Metric tons uranium

Terawatt hour ( 1 million kilowatt hours)

Fuel reprocessing pilot plant near Karlsruhe 


\section{SUMMARY OF NON-US NATIONAL AND INTERNATIONAL RADIOACTIVE WASTE MANAGEMENT PROGRAMS}

1982

\section{INTRODUCTION}

Many nations and international agencies are working to develop improved technology and industrial capability for nuclear fuel cycle and waste management operations. The effort in some countries is limited to research on treating low-level waste from reactor plant operations. In other countries, national nuclear research institutes are engaged in major programs in all phases of the fuel cycle and waste management, and there is a national effort to commercialize fuel cycle operations.

Since late 1976, staff members of Pac if ic Northwest Laboratory have been working under US Department of Energy sponsorship to assemble and consolidate openly available information on foreign and international nuclear waste management programs and technology. This report summarizes the information collected on the status of fuel cycle and waste management programs in selected countries making major efforts in these fields as of the end of June 1982. 



\section{NUCLEAR FUEL CYCLE AND WASTE MANAGEMENT ACTIVITIES}

Five tables are included in this section:

Table 1, "Nuclear Power Plant Capacities," lists the nations operating nuclear power stations and provides the latest data available concerning capacities.

Table 2, "Fuel Cycle Strategy," lists the nations which are operating or planning to construct major fuel cycle facilities.

Table 3, "Industrial Fuel Cycle Activities," indicates the location of major industrial plants.

Table 4, "Fuel Cycle R\&D," lists the nations which have active programs for fuel cycle.

Table 5, "Waste Management R\&D," lists nations which have active waste management activities. 
IABLE 1. Nuclear Power Plant Capacities

\begin{tabular}{|c|c|c|c|c|c|c|c|}
\hline & $\begin{array}{l}\text { Population } \\
\text { (millions, }\end{array}$ & $\begin{array}{c}\text { Total Electric } \\
\text { Power Plant }\end{array}$ & $\begin{array}{l}\text { Nuc } \\
\text { Cap }\end{array}$ & ear $P_{0}$ & $\begin{array}{l}\text { er Pla } \\
\text { t Gwe }\end{array}$ & & \\
\hline Country & 1980 est.) & Capacity (Gwe, 1980) & 1981 & 1985 & 1990 & 2000 & Reactor Type (s) \\
\hline Argentina & 27 & 13 & 0.3 & 0.9 & 1.6 & 4.4 & PHWR \\
\hline Austria & 7.1 & 13 & $0.7 \star$ & & & & BWR \\
\hline Belgium & 9.8 & 13 & 1.7 & 5.4 & 5.4 & 7.4 & PWR \\
\hline Brazil & 119 & 31 & - & 0.6 & 3.1 & 7.9 & PWR \\
\hline Canada & 23.9 & 79 & 5.2 & 10.1 & 14.3 & 23.0 & PHWR \\
\hline China (PRC) & 1000 & $?$ & - & - & - & 6.0 & PWR, HWR \\
\hline Egypt & 42 & 4 & - & - & - & 8.0 & \\
\hline Finland & 4.8 & 12 & 2.2 & 2.2 & 2.2 & 4.2 & $B W R, P W R$ \\
\hline France & 53.5 & 73 & 21.8 & 35.6 & 54.8 & 77.8 & PWR, GCR, FBR \\
\hline Germany (FRG) & 61.5 & 86 & 8.5 & 16.4 & 24.1 & 37.7 & $L W R, F B R$ \\
\hline Greece & 9.7 & & & & & 1.8 & \\
\hline India & 670 & 29 & 0.8 & 1.2 & 1.9 & 4.3 & BWR, PHWR \\
\hline Italy & 56.7 & 51 & 1.3 & 1.3 & 4.2 & 12.8 & BWR, PWR \\
\hline Japan & 117 & 148 & 15 & 21 & 37 & 68 & $L W R, H W R, F B R$ \\
\hline Korea (ROK) & 38 & 6 & 0.6 & 3.6 & 9.3 & 29 & PWR, PHWR \\
\hline Mexico & 69 & 17 & 1.3 & 1.3 & 1.3 & 7.3 & $B W R$ \\
\hline Netherlands & 14.1 & 17 & 0.5 & 0.5 & 0.5 & 0.5 & PWR \\
\hline Pakistan & 81.5 & 2 & 0.1 & 0.1 & 0.1 & 0.7 & LWR, PHWR \\
\hline Philippines & 48.2 & $?$ & - & 0.6 & 0.6 & 2.2 & PWR \\
\hline Portugal & 9.9 & $?$ & - & - & - & 2.7 & \\
\hline South Africa & 28 & 19 & - & 1.8 & 1.8 & 3.8 & PWR \\
\hline Spain & 39.3 & 36 & 2.0 & 7.6 & 12.5 & 21.3 & BWR, PWR \\
\hline
\end{tabular}


TABLE 1. (conta)

\begin{tabular}{|c|c|c|c|c|c|c|c|}
\hline \multirow[b]{2}{*}{ Country } & \multirow{2}{*}{$\begin{array}{l}\text { Population } \\
\text { (millions, } \\
1980 \text { est.) }\end{array}$} & $\begin{array}{c}\text { Total Electric } \\
\text { Power Plant }\end{array}$ & \multicolumn{4}{|c|}{$\begin{array}{l}\text { Nuclear Power Plant } \\
\text { Capacity (Net GWe) }\end{array}$} & \multirow[b]{2}{*}{ Reactor Type(s } \\
\hline & & Capacity (Gwe, 1980) & 1981 & 1985 & 1990 & 2000 & \\
\hline Sweden & 8.4 & 29 & 6.4 & 8.4 & $y .4$ & 9.4 & $B W R, P W R$ \\
\hline Switzerland & 6.3 & 15 & 1.9 & 2.9 & 3.8 & 5.8 & BWR, PWR \\
\hline $\begin{array}{l}\text { Taiwan Republic } \\
\text { of China }\end{array}$ & 17.7 & 9 & 2.2 & 4.0 & 9.6 & 12.6 & BWR, PWR \\
\hline Turkey & 45.3 & $?$ & - & - & - & 1.8 & \\
\hline United Kingdom & 56 & 82 & 6.4 & 10.0 & 10.6 & 18.1 & GCR, FBR, PWR \\
\hline USA & 226.5 & 623 & 56 & 91 & 117 & 150 & LWR, HTGR \\
\hline USSR & 265.5 & 270 & 16 & 34 & 90 & - & PWR, LGR, FBR \\
\hline $\begin{array}{l}\text { Other CMEA } \\
\text { Countries }\end{array}$ & - & $?$ & - & - & 37 & - & PWR, HWR \\
\hline
\end{tabular}

*The 0.7 Gwe Tullnerfeld nuclear plant is installed, but prevented from operation by Austrian law. 
TABLE 2. Fuel Cycle Strategy

\begin{tabular}{|c|c|c|c|}
\hline Country & Fuel Cycle & Spent Fuel Disposition & HLW Management \\
\hline Argentina & $\begin{array}{l}\mathrm{U}-\mathrm{Pu} \text { (CANDU PHWR, } \\
\left.\text { natural } \mathrm{U} / \mathrm{D}_{2} \mathrm{O}\right)\end{array}$ & $\begin{array}{l}\text { Interim--pool storage; long } \\
\text { term--domestic reprocessing. }\end{array}$ & \\
\hline Belgium & $\mathrm{U}-\mathrm{Pu} \quad(\mathrm{LWR})$ & $\begin{array}{l}\text { Reprocess and recycle Pu to } \\
\text { LWR or FBR. Interim-- } \\
\text { foreign reprocessing; long } \\
\text { term--domestic. }\end{array}$ & $\begin{array}{l}\text { Vitrify HLW (French process) } \\
\text { and isolate in clay reposi- } \\
\text { tory. }\end{array}$ \\
\hline Brazil & $\mathrm{U}-\mathrm{Pu} \quad(\mathrm{LWR})$ & $\begin{array}{l}\text { Interim--storage; long term-- } \\
\text { domestic reprocessing. }\end{array}$ & \\
\hline Canada & $\begin{array}{l}\text { U-Pu (CANDU PHWR); con- } \\
\text { version to } 233 \mathrm{U}-\mathrm{Th} \\
\text { PHWR is being evalu- } \\
\text { ated. }\end{array}$ & $\begin{array}{l}\text { Current--long term retriev- } \\
\text { able storage; long term-- } \\
\text { geologic disposal or domes- } \\
\text { tic reprocessing. }\end{array}$ & $\begin{array}{l}\text { Isolate spent fuel or } H L W \text { in } \\
\text { granite repository. }\end{array}$ \\
\hline Finl and & U-Pu (LWR) & $\begin{array}{l}\text { Russian fuels--return } \\
\text { to Russia. Swedish } \\
\text { fuels--geologic disposal } \\
\text { or foreign reprocessing. }\end{array}$ & $\begin{array}{l}\text { Isolate non-Russian spent } \\
\text { fuel or HLW in granite } \\
\text { repository. }\end{array}$ \\
\hline France & U-Pu (GCR, LWR, FBR) & $\begin{array}{l}\text { Reprocess (domestic) and } \\
\text { recycle Pu to FBRs. }\end{array}$ & $\begin{array}{l}\text { Vitrify HLW; provide long- } \\
\text { term interim storage; iso- } \\
\text { late in granite repository. }\end{array}$ \\
\hline Germany (FRG) & $\mathrm{U}-\mathrm{Pu}$ (LWR, FBR, HTGR) & $\begin{array}{l}\text { AFR storage (dry); re- } \\
\text { process (interim--foreign; } \\
\text { long-term--domestic) and } \\
\text { recycle Pu to LWR or FBR. }\end{array}$ & $\begin{array}{l}\text { Vitrify HLW (French process } \\
\text { or German ceramic melter } \\
\text { technology) and isolate in } \\
\text { salt dome repository. }\end{array}$ \\
\hline India & $\begin{array}{l}\text { U-Pu (LWR and CANDU } \\
\text { PHWR); conversion to } \\
233 \text {-Th PHWR is being } \\
\text { evaluated. }\end{array}$ & Domestic reprocessing. & $\begin{array}{l}\text { Vitrify HLW (calcine/melt/ } \\
\text { drain process) and isolate } \\
\text { in geologic repository. }\end{array}$ \\
\hline
\end{tabular}


TABLE 2. (contd)

\begin{tabular}{|c|c|c|c|}
\hline Country & Fuel cycle & Spent Fuel Disposition & HLW Management \\
\hline Italy & U-Pu (LWR) & $\begin{array}{l}\text { Interim storage; reprocess } \\
\text { and recycle Pu to LWR, FBR. }\end{array}$ & $\begin{array}{l}\text { Vitrify HLW (rising-level } \\
\text { pot process) and isolate in } \\
\text { argillaceous formation. }\end{array}$ \\
\hline Japan & U-Pu (LWR, HWR, FBR) & $\begin{array}{l}\text { Reprocess (foreign and } \\
\text { domestic) and recycle } \mathrm{Pu} \text { to } \\
\mathrm{HWR} \text { and FBR. }\end{array}$ & $\begin{array}{l}\text { Vitrify (ceramic melter } \\
\text { process); long-term storage } \\
\text { geologic disposal. }\end{array}$ \\
\hline Korea (ROK) & U-Pu (LWR, PHWR) & To be determined. & \\
\hline Mexico & U-Pu (LWR) & To be determined. & \\
\hline Netherlands & U-Pu (LWR) & Foreign reprocessing. & $\begin{array}{l}\text { Isolate } \mathrm{HLW} \text { glass in salt } \\
\text { dome repository. }\end{array}$ \\
\hline Pakistan & U-Pu (LWR and PHWR) & $\begin{array}{l}\text { Domestic reprocessing; } \\
\text { recycle Pu. }\end{array}$ & \\
\hline South Africa & U-Pu (LWR) & To be determined. & \\
\hline Spain & U-Pu (LWR) & $\begin{array}{l}\text { AFR storage; reprocessing } \\
\text { (interim-foreign; long } \\
\text { term--domestic). }\end{array}$ & \\
\hline Sweden & U-Pu (LWR) & $\begin{array}{l}\text { AFR storage; spent fuel } \\
\text { disposal or foreign re- } \\
\text { processing. }\end{array}$ & $\begin{array}{l}\text { Isolate spent fuel or HLW } \\
\text { glass in granite reposi- } \\
\text { tory. }\end{array}$ \\
\hline Switzerland & $\mathrm{U}-\mathrm{Pu} \quad(\mathrm{LWR})$ & Foreign reprocessing. & $\begin{array}{l}\text { Isolate HLW glass in gran- } \\
\text { ite formation. }\end{array}$ \\
\hline $\begin{array}{l}\text { Taiwan } \\
\text { Republic of } \\
\text { China }\end{array}$ & $\mathrm{U}-\mathrm{Pu} \quad(\mathrm{LWR})$ & To be determined. & \\
\hline
\end{tabular}


TABLE 2. (contd)

\begin{tabular}{|c|c|c|c|}
\hline Country & Fuel cycle & Spent Fuel Disposition & $\mathrm{HLW}$ Management \\
\hline USSR & U-Pu (LWR, FBR, LGR) & $\begin{array}{l}\text { Interim; pool storage; } \\
\text { long-term: Domestic repro- } \\
\text { cessing. }\end{array}$ & $\begin{array}{l}\text { Vitrify HLW and isolate in } \\
\text { geologic repository. }\end{array}$ \\
\hline $\begin{array}{l}\text { United } \\
\text { Kingdom }\end{array}$ & $U-P U(G C R, F B R)$ & $\begin{array}{l}\text { Domestic reprocessing; } \\
\text { recycle Pu to FBR. }\end{array}$ & $\begin{array}{l}\text { Vitrify HLW (French pro- } \\
\text { cess); provide long-term } \\
\text { storage; delay decision on } \\
\text { terminal disposal. }\end{array}$ \\
\hline USA & U-PU (LWR, FBR, HTGR) & Domestic reprocessing. & $\begin{array}{l}\text { Vitrify HLW (ceramic } \\
\text { melter); isolate in geologic } \\
\text { repository (salt, basalt, } \\
\text { tuff). }\end{array}$ \\
\hline
\end{tabular}


TABLE 3. Industrial Fuel Cycle Activities

\begin{tabular}{|c|c|c|c|c|c|c|c|}
\hline & Country & $\begin{array}{l}\text { Uranium } \\
\text { Mining } \\
\text { and Milling } \\
\end{array}$ & $\begin{array}{c}\text { Uranium } \\
\text { Enrichment } \\
\end{array}$ & $\begin{array}{c}\text { Fuels } \\
\text { Fabrication }\end{array}$ & $\frac{\text { Spent }}{\text { AFR Storage }}$ & $\begin{array}{l}\text { Fuels } \\
\text { Reprocessing }\end{array}$ & $\begin{array}{c}H L W \\
\text { Immobilization } \\
\end{array}$ \\
\hline & Argentina & $x$ & & $x$ & & & \\
\hline & Australia & $x$ & & & & & \\
\hline & Belgium & & & $X(\operatorname{MOX})$ & & $P$ & $P$ \\
\hline & Brazil & $x$ & & $x$ & & & \\
\hline & Canada & $x$ & & $x$ & $x$ & & \\
\hline & $\begin{array}{l}\text { Central African } \\
\text { Empire }\end{array}$ & $x$ & & & & & \\
\hline & China (PRC) & $x$ & $x$ & & & & \\
\hline & France & $x$ & $x$ & $x\left(\mathrm{UO}_{2}, \mathrm{MOX}\right)$ & & $x$ & $x$ \\
\hline 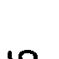 & Gabon & $x$ & & & & & \\
\hline 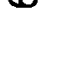 & Germany (FRG) & $x$ & $c$ & $x\left(U 0_{2}, M O X\right)$ & C & $P$ & $P$ \\
\hline & India & $x$ & & $x$ & & $x$ & $x$ \\
\hline & Italy & $x$ & & $x\left(\mathrm{UO}_{2}, \mathrm{MOX}\right)$ & & $P$ & $P$ \\
\hline & Japan & $x$ & C & $x\left(\mathrm{UO}_{2}, \mathrm{MOX}\right)$ & & $x$ & $P$ \\
\hline & Netherlands & & $x$ & & & & \\
\hline & Pakistan & & & & & c & \\
\hline & Spain & $x$ & & $x$ & & & \\
\hline & Sweden & & & $x$ & $c$ & & \\
\hline & USSR & $x$ & $x$ & $x\left(\cup 0_{2}, M O X\right)$ & & $P$ & $P$ \\
\hline & United Kingdom & & $x$ & $x\left(\cup_{2}, \operatorname{MOX}\right)$ & & $x$ & c \\
\hline & USA & $x$ & $x$ & $x$ & & $x$ & \\
\hline & $\begin{array}{l}X \text { - Installed } \\
C \text { - First plant } \\
P \text { - First plant }\end{array}$ & $\begin{array}{l}\text { is under co } \\
\text { is planned }\end{array}$ & truction & & & & \\
\hline
\end{tabular}


TABLE 4. Fuel Cycle R\&D

\begin{tabular}{|c|c|c|c|c|}
\hline \multirow[b]{2}{*}{ Country } & \multirow[b]{2}{*}{$\begin{array}{l}\text { Uranium } \\
\text { Enrichment } \\
\end{array}$} & \multirow[b]{2}{*}{$\begin{array}{l}\text { Mox Fuels } \\
\text { Fabrication } \\
\end{array}$} & \multicolumn{2}{|c|}{ Spent Fuels } \\
\hline & & & $\begin{array}{l}\text { Storage and } \\
\text { Transport }\end{array}$ & Reprocessing \\
\hline Argentina & & $x$ & & $x$ \\
\hline Australia & $x$ & & & \\
\hline Belgium & & $x$ & $x$ & $x$ \\
\hline Brazil & $x$ & & & $x$ \\
\hline Canada & & & $x$ & $x$ \\
\hline France & $x$ & $x$ & $x$ & $x$ \\
\hline Germany (FRG) & $x$ & $x$ & $x$ & $x$ \\
\hline India & & $x$ & & $x$ \\
\hline Italy & & $x$ & & $x$ \\
\hline Japan & $x$ & $x$ & $x$ & $x$ \\
\hline Mexico & & $x$ & & $x$ \\
\hline Netherlands & & & $x$ & \\
\hline Spain & & & $x$ & $x$ \\
\hline Sweden & & & $x$ & \\
\hline USSR & & $x$ & $x$ & $x$ \\
\hline United Kingdom & $x$ & $x$ & $x$ & $x$ \\
\hline USA & $x$ & $x$ & $x$ & $x$ \\
\hline
\end{tabular}


TABLE 5. Waste Management R\&D

\begin{tabular}{|c|c|c|c|c|c|c|c|c|c|}
\hline \multirow[b]{2}{*}{ Country } & \multicolumn{5}{|c|}{ Treatment and Immobilization } & \multicolumn{2}{|c|}{ Disposal } & \multicolumn{2}{|c|}{ Remedial Actions } \\
\hline & $\begin{array}{l}\text { Spent } \\
\text { Fuel }\end{array}$ & HLW & $\begin{array}{c}\text { TRU } \\
\text { Waste }\end{array}$ & LLW/ILW & $\begin{array}{l}\text { Airborne } \\
\text { Wastes } \\
\end{array}$ & Geologic & $\begin{array}{c}\text { Non- } \\
\text { Geologic }\end{array}$ & $\begin{array}{c}\text { Mill } \\
\text { Tailings } \\
\end{array}$ & $\begin{array}{c}\text { Surplus } \\
\text { Facilities }\end{array}$ \\
\hline Argentina & & & & $x$ & & & & & \\
\hline Australia & & $x$ & & & & $x$ & & $x$ & \\
\hline Austria & & $x$ & & $x$ & & $x$ & & & \\
\hline Belgium & & & $x$ & $x$ & $x$ & $x$ & $x$ & & \\
\hline Brazil & & & & & & & & $x$ & \\
\hline Canada & $x$ & $x$ & & $x$ & $x$ & $x$ & $x$ & $x$ & $x$ \\
\hline CEC-I spra & & & & & & $x$ & & & \\
\hline Denmark & & & $x$ & $x$ & & $x$ & & & \\
\hline Eurochemic & & $x$ & $x$ & $x$ & & & & & $x$ \\
\hline Finl and & & & & $x$ & & $x$ & $x$ & & \\
\hline France & & $x$ & $x$ & $x$ & $x$ & $x$ & $x$ & $x$ & $x$ \\
\hline Germany (FRG) & $x$ & $x$ & $x$ & $x$ & $x$ & $x$ & & & $x$ \\
\hline India & & $x$ & $x$ & $x$ & & $x$ & & & $x$ \\
\hline Italy & & $x$ & $x$ & $x$ & & $x$ & & & $x$ \\
\hline Japan & & $x$ & $x$ & $x$ & $x$ & $x$ & $x$ & & $x$ \\
\hline Korea & & & & $x$ & & & & & \\
\hline Mexico & & & $x$ & $x$ & & & $x$ & & \\
\hline Nether 1 ands & & & & $x$ & $x$ & $x$ & & & \\
\hline Spain & & $x$ & & $x$ & & $x$ & & & $x$ \\
\hline Sweden & $x$ & $x$ & $x$ & $x$ & & $x$ & & & \\
\hline Taiwan & & & & $x$ & & & & & \\
\hline USSR & & $x$ & $x$ & $x$ & $x$ & $x$ & $x$ & & \\
\hline United Kingdom & & $x$ & $x$ & $x$ & $x$ & $x$ & $x$ & & $x$ \\
\hline USA & & $x$ & $x$ & $x$ & $x$ & $x$ & $x$ & $x$ & $x$ \\
\hline
\end{tabular}




\section{NATIONAL AND INTERNATIONAL PROGRAM OVERVIEWS}

Brief program overviews of fuel cycle, spent fuel, and waste management activities are provided for countries and international organizations with substantial programs in these areas.

\section{ARGENTINA}

Argentine authorities expect to have the country's hydroelectric power potential, estimated at a total of 25 GWe, fully developed by 1995 and are placing a high priority on nuclear power to meet additional electrical power requirements. The country has one PHWR ( 0.36 GWe) installed, two PHWR ( 1.3 GWe) under construction, and is aiming for a total 4.4 GWe nuclear by the year 2000 .

Major objectives are to:

1. Develop a strong, self-sufficient nuclear power industry based on the CANDU-type PWR and heavy water-natural uranium fuel cycle. Target dates: reactor construction capability by 1985-1990; fuel cycle capability by 1985 .

2. Become the supplier of reactor plants and fuel cycle services to Latin American and other less-developed countries.

\section{ORGANIZATION}

The Comisión National de Energía Atomica (CNEA--National Atomic Energy Commission), Buenos Aires, owns and operates all facilities, including the Ezeiza Atomic Centre, located about 10 miles northwest of Buenos Aires.

\section{NUCLEAR FUEL CYCLE}

\section{Fuels Production}

Argentina has uranium ore reserves containing an estimated $27,000 \mathrm{t}$ of easily accessible uranium and an additional 31,000 $t$ or more available at 
higher cost. Mining and milling capacity (260 t/yr in 1981) is to be expanded to $680 \mathrm{t} / \mathrm{yr}$ by 1985 .

The government has two $\mathrm{UO}_{2}$ conversion $\mathrm{lines}$ and a new $\mathrm{UO}_{2}$ fuel and zircaloy tubing fabrication plant at Ezeiza. The first fabrication line (1.5 PHWR assembly per day) started up in April 1982. When the plant reaches full capacity (1987), it will produce $33 \mathrm{t}$ of zircaloy per year and $300 \mathrm{t}$ of uranium. $(2-4)$

Fuel Reprocessing

Argentina operated a small experimental reprocessing facility from 1967 to the early 1970s. A new pilot reprocessing plant has been built at Ezeiza, with a reportedly $20 \mathrm{~kg} / \mathrm{day}$ capacity. It is scheduled for cold operation in 1983 and hot run testing in 1984. Consideration is being given to construction of a larger pilot plant and a commercial plant, with proposed startup dates of 1986-1990 and 1995-2000, respectively. ${ }^{(4)}$

Waste Treatment

The Argentine government has announced plans to build an experimental solidification plant for undefined "high activity" wastes. Startup is expected in 1985.

Wa ste Isolation

Preliminary plans have been made for evaluation of four sites for potential use as a HLW repository. Currently the preferred site is located at Sierra del Medio, $350 \mathrm{~km}$ northeast of Rawson in Chubut province. All four sites contain igneous granite rock. CNEA intends to use the facility for interim AFR storage of spent fuel, pending development of reprocessing capability and a HLW disposal system.

\section{AUSTRALIA}

Australia's resources used for energy production are greater than domestic consumption by about $20 \%$, but the country imports about $30 \%$ of the $0 i 1$ it uses. In 1979, Australian power plants generated 90.9 TWh of electric energy, from solid fuels (20.1 Mtoe), oil (1.5 Mtoe), gas (1.4 Mtoe), and hydro (4.2 Mtoe). ${ }^{(5)}$ 
Even though Australia is a major uranium producer, no commitment has been made to nuclear power plant construction. The government of Western Australia is considering the construction of a 1000-MWe station at two possible sites north of Perth. The Northern Territory recently made plans to build a large LWR or HWR near Darwin, but these were rejected for economic reasons. Meanwhile, the Australian Atomic Energy Commission (AAEC) is conducting R\&D on HTGR and LMFBR systems, giving the highest priority to the HTGR.

The government has a strong interest in nuclear power because of its desire to export Australian uranium. Feasibility studies have been conducted on the manufacture of $U_{6}$ and on commercial enrichment of uranium by gas centrifuge or laser enrichment, possibly within 10 years. Exploratory talks have been held with a number of organizations in other countries looking to a potential cooperative uranium enrichment venture. The government has evidenced strong positive attitudes toward nonproliferation and is expected to impose stringent controls on the use of its exported uranium.

\section{ORGANIZATION}

The Australian Atomic Energy Commission (AAEC) is an agency of the Ministry of State for Minerals and Energy. Nuclear research and development is carried out mainly at the AAEC Research Establishment, Luc as Heights, in Sutherland, New South Wales (near Sydney) with contributions from some of the universities.

\section{NUCLEAR FUEL CYCLE}

Uranium Production

The country's reasonably assured uranium resources are now estimated at about 300,000 tU. Uranium mining and milling, currently estimated at $2300 \mathrm{t} /$ $\mathrm{yr}$, is expected to increase to 12,000 tU/yr by 1985 and 20,000 tU/yr by 1990 . High-Level Waste Immobilization ${ }^{(6)}$

Although Australia has no plans for commercial spent fuel reprocessing and terminated its R\&D on reprocessing of HTGR fuels in the 1960s, the government is sponsoring the development of the SYNROC process for immobilizing the radionuclides in high-level wastes. 
The SYNROC process, conceived at the Australian National University (ANU), Canberra, produces a mixture of synthetic mineral phases characterized by two key properties: great geochemical stability and the ability to incorporate into solid solution all the important radionuclides present in the waste. Basic SYNROC ingredients are $\mathrm{TiO}_{2}, \mathrm{ZrO}_{2}, \mathrm{Al}_{2} \mathrm{O}_{3}, \mathrm{CaO}, \mathrm{BaO}$, and up to $10 \mathrm{wt} \%$ waste calcine. The reaction of the ingredients to form the synthetic mineral phases, and fabrication of the waste form can be accomplished by some form of solid state process, such as hot pressing or sintering. The first engineeringscale demonstration was achieved at Lucas Heights in November 1981.

SYNROC studies are continuing at ANU, with the emphasis on process basics, and at the Lucas Heights Laboratory, where the focus is on process scale-up. Management of Mine and Mill Tailings

The AAEC studies of technology to reduce the environmental impact of uranium mining and milling have been focused mainly on improvements in the control of radium and radon. The program includes:

1. study of radium and heavy metal concentrations in tailings and process waste solutions

2. determination of factors affecting the natural leaching of radium from tailings

3. laboratory studies of the feasibility of chemical extraction of radium by leaching in strong salt solutions

4. determination of radon release from ores and tailings under various conditions; assessment of the feasibility of removing radon from air streams

5. studies of surface hydrology at prospective mines and mills. Geologic Waste Isolation

Australia has large ore bodies located near the surface in areas subject to high seasonal rainfall and periodic flooding. Past movement of radionuclides $\left({ }^{238} \mathrm{U},{ }^{234} \mathrm{U}\right.$, and ${ }^{230} \mathrm{Th}$ ) under these extreme (but natural) conditions is being analyzed by AAEC to provide a basis for the construction of a model of radionuclide movement through clay over a time span of about one-half million years. 


\section{$\underline{\text { AUSTRIA }}$}

Austria produces coal, oil, and gas in limited quantities, but depends upon imports for 50-60\% of its primary energy. In 1979, Austrian power plants generated 40.6 TWh of electric energy from hydro (6.6 Mtoe), oil (1.1 Mtoe), gas (0.8 Mtoe), and solid fuels (0.6 Mtoe). (5)

Austria has built one nuclear power plant, the Tullnerfeld 730-MWe BWR at Zwentendorf near Vienna, and at one time planned two additional 1000-MWe nuclear plants. However, in a 1978 plebiscite the Austrian voters indicated by a small margin their opposition to nuclear power. The Parliament then passed the "Nuclear Power Plant Ban Act", forbidding the use of nuclear power to generate electricity and prohibiting the startup of Tullnerfeld. The majority of Austrian voters probably now favor operation of the Tullnerfeld plant, but the political situation is such that repeal of the law would be difficult and the future of Austrian nuclear power is highly uncertain. (7)

In the meantime, the company formed to erect and operate the plant, GKT, has sought to obtain reimbursement of its investment as well as funds to dismantle the plant ( $\$ 500$ million) from the federal government, charging that government has, in effect, taken possession of the plant. This has been rejected by an administrative court, but will probably be appealed.

Until the Tullnerfeld decision, the Austrian nuclear utilities had planned to have their spent fuels reprocessed by COGEMA at La Hague, with the vitrified HLW returned to Austria for disposal. Contracts with COGEMA were cancelled in 1979.

Although nuclear power generation is illegal in Austria, the government is proceeding with reactor safety, waste treatment, and waste isolation R\&D and has joined with Egypt in studies of potential cooperative waste storage in Egypt.

\section{ORGANIZATION}

The Federal Ministry of Health and Environmental Protection is the principal nuclear authority at the national level and oversees adherence to the 
radiation protection laws. Waste treatment and disposal are the responsibility of the Austrian Atomic Energy Research Company (SGAE), which is headquartered in Vienna and has a laboratory at Seibersdorf.

\section{WASTE MANAGEMENT ${ }^{(7)}$}

Low-level waste generated in Austria's nuclear research program and in medical applications is stored at the Seibersdorf Nuclear Research Center. The Seibersdorf Center has developed processes for incineration and immobilization of LLW and has studied alternative techniques for treating HLW, such as production of coated waste particles or granules.

Prior to the passage of the 1978 antinuclear law, the country was surveyed for potential repository sites, and preliminary thought given to building a repository in a granite formation. Thermal and hydrologic studies were initiated and several exploratory holes up to $100 \mathrm{~m}$ in depth were drilled.

\section{$\underline{B E L G I U M}$}

Belgium has indigenous resources for only $15-20 \%$ of the energy consumed in the country, and imports all the gas, oil, and much of the coal it uses. In 1979, Belgium power plants generated 48.4 TWh of electric energy from oil (3.6 Mtoe), solid fuels (2.8 Mtoe), nuclear (2.5 Mtoe), gas (2.2 Mtoe), and hydro (0.1 Mtoe).

Belgium has three PWRs (1.65 GWe) operational and four (3.8 GWe) under construction. When all are on line in late 1984, nuclear power will account for about $40 \%$ of the country's total electrical generating capacity. The utilities have requested government approval for two new 1.3-GWe nuclear plants, to reduce their dependence upon imports, but the government has deferred a decision unt $i l$ the results are in from a long-delayed parliamentary debate on nuclear energy.

Belgium started to develop a strong fuel cycle capability with the Eurochemic processing plant and a Franco-Belge fuel fabrication plant located in the country and with a strong research center (at Mol). The capability is eroding somewhat, with slowdown of the nuclear program, government indecision 
concerning a national power plan, and the retrenching of Belgian vendors. The country could become a strong supplier of MOX fuels for LWRs and FBRs.

Fuel cycle and waste management plans, yet to be acted upon by the government, assume reprocessing, recycle of plutonium to FBRs or LWRs, immobilization of all wastes, disposal of LLW in the ocean, and terminal isolation of HLW and alpha-active wastes in a deep clay repository.

ORGANIZATION

Government sponsored nuclear research and development in Belgium is coordinated and performed primarily by the Nuclear Energy Research Center (CEN/SCK) at Mol, which also treats and disposes of LLW and ILW generated in the country.

Responsibility for AFR spent fuel storage and for the transport, conditioning, and storage of radioactive wastes is being turned over to a new organization, the National Institute for the Treatment of Radioactive Wastes (NIRAS /ONDRAF).

Commercial fuel cycle activities are handled by private companies which are partly owned and controlled by the government, through CEN/SCK, and partly by the nuclear utilities in Belgium.

- Belgonucléaire S.A. is a manuf acturer of mixed oxide $\left(\mathrm{PuO}_{2}-\mathrm{UO}_{2}\right)$ fuel pins and assemblies for fast breeder reactors and for recycle to LWRs.

- A new company, Société Belge de Combustible Nucléare, owned $50 \%$ by the government and 50\% by private industry, will take over ownership and operation of the Eurochemic facilities if they are transferred to Belgium.

The Eurochemic Company and its facilities, established as a multinational project by the OECD, are also located at Mol. 


\section{NUCLEAR FUEL CYCLE}

\section{Fuels Production}

Belgium has part ownership in the Eurodif gaseous diffusion plant in France. In keeping with Belgian plans to develop plutonium recycle and fast breeder reactor capability, Belgonucléaire built and operates pilot-scale (60-t/yr) facilities at Mol for Mox fuel fabrication.

Fuel Reprocessing (8)

The Eurochemic plant at Mol, with a capacity of $0.3 \mathrm{tHM} / \mathrm{day}$ of lowenriched uranium fuels, operated from 1966 to 1974. It has been decontaminated and may be refurbished and resume operation under Belgian ownership. In a related effort, CEN/SCK, Belgonucléaire and ENI are building the HERMES $p$ ilot plant for FBR fuel reprocessing head-end and off-gas control studies. HERMES startup is scheduled for 1982.

Waste Treatment $(7,9,10)$

Liquid LLW from Belgian nuclear power plants is treated at the reactor site, encased in concrete, and shipped to CEN/SCK at Mol for disposal. Solid LLW is shipped to Mol for incineration or immobilizing in bitumen or concrete. CEN/SCK has placed in operation a high-temperature $\left(>1400^{\circ} \mathrm{C}\right)$ slagging incinerator which handles low-level reactor wastes and is being prepared to burn Pu-contaminated wastes.

Eurochemic has installed several facilities for treatment and storage of low- and intermediate-level wastes from the reprocessing plant: Eurobitum, a $650-\mathrm{m}^{3}$ /yr bituminization plant; Eurostorage, for storage of conditioned wastes; and Eurowatt, a pilot facility for treating waste PUREX solvent. Eurochemic is also the site of an acid digestion plant for combustible TRU waste, built and operated by Germany's Karlsruhe Nuclear Research Center.

The Eurochemic Company is obligated to solidify its stored high-level liquid waste and plans to join with Belgium in building a French AVM-type vitrification plant at Mol. It is assumed that a Belgian company will operate the plant. 
Eurochemic has maintained a HLW solidification R\&D program for several years and developed the Vitromet waste form (glass marbles in a metal matrix). The Eurochemic staff is currently assisting DWK (the German fuel cycle company) in the ir program to demonstrate a joule-heated ceramic melter vitrif ic ation system in the new PAMELA pilot plant at Mol. Waste Disposal $(7,12)$

Low-plutonium wastes which meet the international sea-dump criteria are dropped into the Atlantic at depths of about $4000 \mathrm{~m}$, under the supervision of the OECD/NEA. LLW unsuitable for ocean dumping is stored at the Mol site.

With cosponsorship from CEC, Belgium is developing clay repository technology (site and media characterization, corrosion effects, repository design, risk analysis, and in situ tests) and intends to have a test repository operational at Mol by 1983 . The work is coordinated by CEN/SCK.

Evaluation of preliminary tests indicates that tunnels and underground facilities can be constructed in the Boom clay formations at Mol, at depths up to $250 \mathrm{~m}$, and that a thermal load of about $15 \mathrm{~kW}$ per hectare can be tolerated. Heater experiments and the construction of a test chamber $(350 \mathrm{~m}$ iong by $30 \mathrm{~m}$ wide) under the Mol site are under way.

Major Milestones

- Refurbish Eurochemic reprocessing piant

- HADES geologic test repository

- Industrial repository

- Vitrification plant for existing Eurochemic waste (HEWC)

$\begin{array}{rr}\text { After } & 1984 \\ 1983 \\ 1990 \\ 1987\end{array}$

BRAZIL

Brazil has limited indigenous sources of crude oil, shale oil, natural gas, and coal, and imports $80 \%$ of the $0 i 1$ the country uses. Brazil's total electric power production capacity is about 30 GWe. Of the country's hydroelectric potential, estimated at $200 \mathrm{GWe}$, only $23 \%$ is currently committed to use, but most of the uncommitted hydroelectric sites are in isolated areas and not readily accessible. (13) 
Brazil has one PWR (0.6 GWe) in operation, two under construction, and six more on order. The program is scoped to give a total nuclear capacity of about $10 \mathrm{GWe}$ by about the year 2000. The introduction of FBRs is also an important objective, and Brazil has an FBR exchange agreement with Italy.

The nation has an ambitious program to develop complete LWR fuel cycle (and reactor) independence, based upon an equipment and technology acquisition agreement with FRG.

\section{ORGANIZATION}

Nuclear power policy is planned, executed, and controlled through the Brazilian Ministry of Mines and Energy. Directly subject to the Ministry is the Brazilian Nuclear Energy Commission (CNEN), which has regulatory, standardization, licensing, planning, surveillance, safety evaluation, and operator training functions.

Also subject to the Ministry are two companies responsible for the execution of the program: Electrobrás, a holding of the Brazilian electric utilities and Nuclebrás, a federal nuclear power enterprise. Nuclebrás is responsible for plant engineering, project preparation, civil construction, and equipment erection.

Major facilities include the Center for the Development of Nuclear Technology at Belo Horizonte and a fuel cycle complex at Resende in the state of Rio de Janeiro.

\section{$\underline{\text { NUCLEAR FUEL CYCLE }}^{(2,14)}$}

Uranium reserves in Brazil are estimated at about 265,000 tonnes. Ful1scale $(500 \mathrm{t} / \mathrm{yr})$ production of yellow cake was initiated in the spring of 1982 at the Pocos de Caldas complex in the state of Minas Gerais. A complex including a UF 6 conversion plant, a demonstration enrichment plant employing the Becker nozzle enrichment process, and a $\mathrm{UO}_{2}$ fuel fabrication plant rated at $400 \mathrm{tU} / \mathrm{yr}$ is under construction at Resende. 
Nuclebrás is building a $10-\mathrm{kg} / \mathrm{d}$ ay pilot reprocessing plant in the Rio de Janeiro area. Startup is planned for 1984. The company is also considering the construction of an industrial-scale reprocessing $\mathrm{plant}$.

\section{CANADA}

Canada is a net exporter of energy, domestic production exceeding consumption by about $10 \%$ in 1979, but is dependent on oil imports to a significant extent. In 1979, Canadian power plants generated 363.4 Th of electrical energy from the following sources; hydro (55.7 Mtoe), solid fuels (13.7 Mtoe), nuclear ( 8.1 Mtoe), oil (3.3 Mtoe), and gas (1.7 Mtoe). (5)

Canada has 9 PHWRs and 1 BLWR installed and 13 PHWRs under construction. The PHWRs use the Canada deuterium uranium (CANDU) PHWR system, which burns natural uranium $\mathrm{UO}_{2}$ fuel and is both cooled and moderated with heavy water. On-line nuclear generating capacity, 5.2 GWe, accounts for about $10 \%$ of the electricity generated in Canada. In Ontario Province, where 9 of Canada's 10 power reactors are located, about 30\% of the electricity comes from nuclear energy. Current projections of future nuclear power capacity are set at 23 GWe by the year 2000 .

The government strongly supports the nation's nuclear program, which is being developed exclusively around domestic suppliers. The nation has an active, close-knit fuel cycle and waste disposal program. Virtually all R\&D, policy, and decisions for implementation are made by the government or AECL and appear directed toward evolution of the CANDU reactor system and reservation of uranium for national needs. The government program is strongly supported by private industry in uranium production, reactor equipment manufacture, and fuel fabrication. Large-scale exports of uranium should continue, but it is doubtful that CANDU fuel exports will ever become a major business.

ORGANIZATION

At omic Energy of Canada Limited (AECL), a federal agency, is responsible for the development of nuclear power systems for domestic use and export. 
Organized as a "Crown Company" in 1952, AECL's stock is held by the Minister of Energy, Mines and Resources. The company is governed by a board of directors drawn from commerce, industry, universities, and utilities. In 1978, $A E C L$ was reorganized into a holding company with four subsidiaries, the $A E C L$ Engineering, Chemical, Radiochemical, and Research Companies. The AECL Research Company is responsible for the Chalk River and Whiteshell research laboratories. Whiteshell is responsible for all radioactive waste management R\&D except that done for reactor wastes and for reactor decommissioning, which has been assigned to Chalk River.

Other Canadian organizations with major roles include:

1. Atomic Energy Control Board (AECB), a federal agency with responsibility for licensing and safety, security, and environmental concerns

2. Geologic Survey of Canada, a branch of the Department of Energy, Mines and Resources, which handles field assessments, drilling, and geophysics

3. Mining Research Laboratories of 0ttawa, also part of the Department of Energy, Mines and Resources, which are concerned with mill tailings management, rock properties, shaft and borehole sealing tests, and underground heater tests

4. Inland Waters Directorate, Department of Environment, which undertakes hydrologic, geochemical, and radionuclide transport studies

5. Ontario Hydro, a utility headquartered in Toronto, which has made a major commitment to nuclear power production and which works closely with AECL in areas of technology of direct conern to a nuclear utility.

NUCLEAR FUEL CYCLE

Fuels Production

Canada has reasonably assured uranium reserves, estimated at 258,000 $\mathrm{t}$ and expects to increase its uranium mining and milling capacity to $12,500 \mathrm{tU} / \mathrm{yr}$ by 1985. The CANDU reactor system does not use enriched uranium, but $\mathrm{D}_{2} \mathrm{O}$ is required, and the country has heavy water facilities as well as CANDU fuel manufacturing plants. 
Spent Fuel Management ${ }^{(7)}$

Canada has sufficient uranium reserves to continue operating its CANDU reactors without fuel recycle well into the next century. Current thinking is that reprocessing is unlikely to become economical for CANDU fuels for many years. Because a decision to reprocess $\mathrm{UO}_{2}$ fuels for recovery of plutonium may be made eventually, and because the use of the Th- ${ }^{223} \mathrm{U}$ fuel cycle is being evaluated, Canada has a small reprocessing R\&D activity at Whiteshell, and the waste management program is preparing for long-term isolation of either spent fuels or wastes from reprocessing as well as nuclear power plant wastes.

In view of the uncertainty concerning reprocessing, Canadian policy is to store spent fuel indefinitely (at least 50 years) at the reactor sites in water basins. Systems for centralized storage, either air-or water-cooled, are under investigation by $A E C L$ and Ontario Hydro. Waste Treatment $(15-17)$

AECL's Chalk River Laboratories studied the incorporation of fission products in aluminosilicate glasses about 20 years ago. In 1960, glass blocks containing high-level fission products were placed in swampy ground below the water table. Water samples taken since that time have shown almost negligible fission product leach rates.

Whiteshell investigators are currently studying the immobilization of spent fuel wastes in glass and ceramic materials. Their objective is to develop a ceramic melter vitrification process for high-activity wastes from reprocessing thorium fuels. Whiteshell also has a waste form characterization program under way.

Other waste treatment studies include:

1. Treatment and immobilization of reactor wastes by reverse osmosis, combustion, and bituminization. The major facility for this development is the Waste Treatment Centre at Chalk River, designed for fullscale demonstration of the processes of interest.

2. Recovery of volatile radionuclides from fuel reprocessing operations and incorporation of noble gases in solids such as zeolites (Whiteshe11). 
3. Management of uranium mill tailings, with work on radium control, environmental impacts and use of grout around tailings ponds (various organizations).

Disposal of Reactor and Other Low-Level Wastes $(7,15,17)$

Four operational LLW storage sites are in existence, two on AECL property and two on utility property. LLW from research facilities and from commercial reactors is reduced in volume and shipped to one of those disposal sites for shallow burial or storage.

In 1981 the federal goverrment approved continuation and expansion of Canadian geologic repository studies in a 10-year, spent fuel waste management program funded at $\$ 30$ M (Canadian) per year for the next three years. Spent fuel waste is defined as either spent fuel or immobilized HLW. The program, coordinated by whiteshe11, includes:

1. Development of canisters for spent fuels to be emplaced in a repository. Most of the work to date has been done on providing a protective shell for intact fuel bundles which will prevent their collapse under geostatic pressures in the repository (Whiteshe11). Two alternatives are being studied: a containment system designed to immobilize the fuel completely for 300-500 years, until most of the radioactivity has decayed; and an advanced system designed to provide containment for a much longer period.

2. Studies of those properties of irradiated fuels which determine its performance as a waste form (Whiteshell).

3. Development of repository technology. Many potential repository sites have been located, most of them in granite formations in the Precambrian shield of Ontario Province, and most of the Canadian geologic disposal effort is applied to granite repository technology. Other media including salt, limestone, and shale are considered possible alternatives, but work on these is very limited.

The current Canadian program is focused on the development of the Underground Research Laboratory (URL), which is to be mined out of a virgin granite 
formation near the whiteshell establishment. The URL project is to be used to demonstrate methods and techniques for locating and assessing typical granitic rock formations being considered for waste repositories, obtain site characteristics from surface and subsurface explorations in pristine rock, develop predictive models, and eventually confirm the site characteristics through underground experiments. Drilling of boreholes for site characterization has started, and design of the laboratory and of the experimental program are under way.

Supporting studies (hydrology, rock mechanics, migration of radionuclides, safety assessment, etc.) are conducted at Whiteshell and by components of the Department of Environment; the Department of Energy, Mines and Resources; and a number of other organizations.

Major Milestones

- Underground Research Laboratory (WNRE)

- Spent fuel immobilization pilot plant

- Complete concept verification for a geologic repository

- Permanent emplacement of radioactive waste in a repository.

$1985-86$

Mid-1980s

1990

After 2000

\section{CHINA (PEOPLE'S REPUBLIC)}

In 1976, total energy consumption in the People's Republic of China was equivalent to 415.5 million tonnes of $0 i 1$, most of it from indigenous coal and 0i1. In 1977, the country generated 150 TWh of electric energy from thermal and hydroelectric plants. Energy demand is rising rapidly, but Chinese planners are concerned that increased use of coal and hydropower will not meet the needs. The government is planning a big nuclear power program, starting with its current development of a 300-MWe PLWR using indigenous technologies, and the prototype 125-MWe High-Flux Engineering Test Reactor (HFETR). China plans to develop thermal reactors, with breeders and fusion for the long term. (18-20)

Nuclear experts have advised the government to construct six 1000-MWe units. They recommended that two be built near Hong Kong in the South, two near Shanghai in the East, and two in Liaoning Province, all regions where 
acute power shortages exist. Although discussions continue between China and Hong Kong on a joint project to build two 900-MWe nuclear power plants near Guanzhou (Canton), Chinese approval has not yet been secured. Uranium resources are adequate for these plans, and there is nigh potential for discovery of more.

The expansion is part of the government's ambitious "Four Modernizations" program. Nuclear energy progress seems essential because China's energy production lags far behind its increased energy consumption.

\section{ORGAN IZATION}

The government's Second Ministry of Machine Building is responsible for all fields of nuclear power development. In 1980 the Scientific and Technological Commission created a special panel, staffed by 38 nuclear specialists and science administrators, to deal with matters regarding nuclear fuel, equipment, safety, etc.

Nuclear R\&D is done at the Atomic Energy Research Institute of The Academy of Sciences in the Peking area, and at the Southwest Research Institute (SWRI) near Chengdu.

\section{NUCLEAR FUEL CYCLE}

China's current nuclear program, developed for weapons production, is well developed on a small scale. China has facilities for uranium conversion, uranium enrichment by gaseous diffusion, fuel element fabrication, and reprocessing of spent fuel from plutonium production reactors in a purex process plant. Heavy water, zirconium, and other materials are available in snall quantities. Several production and research reactors are operating.

Chinese scientists have gained experience in nuclear waste disposal through the military production program: high-level and intermediate-level wastes are now stored in tanks; low-level waste, after treatment, is discharged into rivers; gaseous waste is discharged through high stacks after filtration and dilution. R\&D is being done on fuel reprocessing; high-level waste vitrification; fixing of intermediate-level waste in bitumen, cement, or 
plastics; treatment of LLW containing trans-plutonium elements; recovery of krypton-85; and extraction of fission products and actinides from HLW.

\section{DENMARK}

Denmark is heavily dependent upon imported coal and oil, with only three percent of its energy requirements coming from indigenous sources. In 1979, Danish power plants generated 20.8 TWh of electrical energy from solid fuels (3.5 Mtoe) and oil (1.8 Mtoe). (5) In 1976, the Minister of Energy presented an energy plan to Parliament which called for five nuclear power stations to be completed by 1995. Because of public opposition, however, the decision to introduce nuclear power has been postponed several times. In May 1980, the decision was again delayed for at least 2 years. In the meantime, the utility organizations ELSAM and ELKRAFT have continued to plan for nuc lear power. They have investigated potential power station sites and have sponsored design, feasibility, and site characterization studies for a salt dome repository.

ORGANIZATION

The Atomenergikommisionen (Danish Atomic Energy Commission), located in Copenhagen, has overall responsibility for nuclear energy matters. R\&D in the nuclear field is performed primarily by the Research Establishment Ris $\varnothing$ at Roskilde. The Ministry of the Environment is charged with evaluating the results of repository field studies and the safety analysis.

WASTE MANAGEMENT R\&D $(21,22)$

Danish investigators ( $R i s \phi)$ have been studying radioactive waste treatment and disposal for a number of years. They made, in fact, the first known tests of a joule-heated ceramic melter for vitrifying simulated HLW. They have since been interested in the treatment of low-level wastes, TRU properties, and geologic disposal of high-level wastes.

In 1977, ELKRAFT and ELSAM initiated a two-phase study of Denmark's waste disposal potential. Phase I, a preliminary evaluation of waste disposal practices and programs, was completed with the publication of a report entitled 
"Disposal of High-Level Waste from Nuclear Power Plants in Denmark--Salt Dome Investigations." Phase II, a 2-year project funded at $\$ 10 \mathrm{M}$ by the utilities, was completed with a report to the government in May 1981. The plan was to look at four salt domes in Denmark, select two sites, complete an initial design, and do some field work, including drilling two or three boreholes.

A number of salt domes in the northern part of Jutland has been evaluated. Two sites have been drilled to a depth of $3500 \mathrm{~m}$ below sea level, and one of them eliminated because of the complexity of the formation. Hydrologic studies and measurement of the properties of the remaining site are under way. Facility design, materials testing, and safety assessments are also proceeding.

Two concepts--deep-hole disposal to a depth of about 2500 meters and a shaft-gallery concept, with the gallery at a depth of 1200 meters--are being investigated.

Research on a low-level waste repository has been conducted in connection with the HLW program. The current concept is to use a shaft/mine concept, also located in a salt dome.

Investigators at the Ris $\phi$ National Laboratory are studying the migration of radionuclides through soils in a project partly financed by the CEC. Emphasis has been $p l a c e d$ on the effect of various complexing agents upon migration.

\section{FINLAND}

Finland imports the oil and coal which supply most of the nation's demand for primary energy (24.7 Mtoe in 1978). (23) The first energy program of the government of Finland, approved in 1979, set a goal of a $20 \%$ reduction in oil consumption by 1990. This is to be accomplished through a significant increase in nuclear power, stepped-up domestic energy production (hydropower, peat, and industrial waste), and conservation.

Finland has four nuclear power plants, two 420-MWe PWRs supplied by the USSR, and two 660-MWe BWRs supplied by ASEA-Atom in Sweden. The present nuclear power capacity of 2.2 GWe is expected to increase to between 3.2 and 5.2 GWe by the year 2000. The next plant to be built will be ordered from the USSR or France. 
ORGANIZATION

The Finnish government oversees nuclear affairs through the Atomic Energy Commission, which is a component of the Energy Department in the Ministry of Trade and Industry. The nuclear power stations are operated by two state-owned power companies, Imatran Voima Oy (IVO) and Teollisuuden Voima Oy (TVO). These companies have established the Nuclear Waste Commission of Finnish Power Companies (Voimayhtiöiden ydinjätetoimikunta, YJT) to coordinate studies related to the management of their nuclear wastes.

Waste management R\&D is carried out mainly by the Technical Research Centre (VTT), the Geological Survey of Finland (both located near Helsinki), and the Institute of Radiation Protection.

NUCLEAR FUEL CYCLE

Finland has no commercial fuel cycle capability, and fuel cycle and waste management policy depends on the reactor supplier. Spent fuel from the USSRbuilt PWRs (440 MWe each) is to be returned to Russia for handling and disposal with no wastes to be returned to Finland. The first shipment--fuel cooled for three years--occurred in the fall of 1981. Spent fuel from the Swedish PWRs (660 MWe each) may be sent to another country for reprocessing or placed in terminal storage by Finland.

WASTE MANAGEMENT $^{(24)}$

The Loviisa Power Station has tank storage facilities for wet reactor waste, and plans are being made to build a cementation facility by 1983 . Wet reactor wastes from $01 \mathrm{kiluoto}$ are solidified in bitumen.

Finnish R\&D programs are directed primarily at developing technology to condition and dispose of reactor wastes and to dispose of either spent fuels or fuel reprocessing wastes. The two power companies are evaluating various reactor waste treatment methods--incineration, cementation, and bituminization. The companies are also evaluating the disposal of reactor wastes (including the debris from dismantling) in a geologic repository and (with VTT) the placement of low-level wastes in shallow land disposal sites. 
In 1977, the Geological Survey of Finiand started a project to evaluate the possibility of disposing of Finland's spent fuels and/or solidified HLW in one of the country's granite formations. An inventory is being made of possible sites; geologic, hydrologic, and radionuclide migration are being studied; and other supporting studies are in progress. In addition to the Geologic Survey, participants include the University of Helsinki and the Helsinki University of Technology, VTT, and the Institute of Radiation Protection. Finland is also a participant in the NEA joint R\&D studies in the Stripa mine in Sweden.

VTT investigators at Espoo are also conducting risk assessment studies and an economic evaluation of the back end of the fuel cycle.

The utilities expect to have underground storage facilities for reactor wastes by the 1 ate 1980 s or early 1990s. Final disposal of spent fuels or HLW is not expected to begin before the 2020s.

\section{FRANCE}

France depends heavily on foreign supplies of fossil fuels: in 1979, France imported $75 \%$ of its total energy and $99 \%$ of its 011 . French authorities consider nuclear power to be the one alternative energy source capable of replacing oil in the short and mid terms, and France maintains an aggressive nuclear power program. In 1981 French plants generated about 265 TWh of electric energy from nuclear (38\%), thermal--coal and oil (35\%), and hydro $(26 \%) .(20,25)$

France has 22 PWRs (19.4 GWe), seven GCRs (2.2 GWe), one LMFBR (0.2 GWe), and one GCHWR (70 MWe) operational. Twenty-seven PWRs (29.5 GWe) and one LMFBR (1.2 GWe) are under construction or on order. Under the previous government, 30 identical 950-MWe units had been scheduled to come on-line in the future, one every two months. The new government is less supportive of the nuclear option, but has only reduced the 1990 objective to 53 GWe (from 59).

France is very aggressive in developing domestic nuclear power and fuel cycle capability; marketing fuel cycle services; and exporting equipment, plants, and technology. 
At the present time, emphasis is being placed on expansion of fuel reprocessing capacity to satisfy domestic and foreign requirements, demonstration of the FBR fuel cycle, and development of waste treatment technology and industrial plants. France also has a very active nuclear research program, which strongly emphasizes the practical application of technology.

ORGANIZATION

The French Atomic Energy Commission (Commissariat à L'Énergie Atomique, CEA), operating under the direct authority of the Ministry of Research and Technology, is responsible for controlling all nuclear R\&D and fuel cycle activities from research to defense. Principal responsibility for fuel cycle and waste management technology and safety is divided among the Director for Nuclear Energy Applications (spent fuel reprocessing); the Director for Nuclear Protection and Safety (head of the Institute for Protection and Nuclear Safety); and the Director for Nuclear Waste Management. Fuel cycle and waste management $R \& D$ are carried out at a number of CEA nuclear research centers, the major responsibility for spent fuel reprocessing and high-level waste treatment $R \& D$ resting with the CEA's Chemical Division which has its headquarters and $f a c i l i t i e s$ at the Fontenay-aux-Roses research center (CEN-FaR) as well as some facilities at Cadarache and Marcoule. Commercial fuel cycle activities, once managed by the CEA, are now the responsibility of a CEA subsidiary, COGEMA. COGEMA was formed in January 1976 to manage the CEA fue 1 cycle complex on an industrial basis. The policy is to offer integrated services covering the entire nuclear fuel cycle, including fuel management, and to develop an active exporting policy in this field. Other CEA components with major fuel cycle responsibility are the Institute for Nuclear Protection and Safety (IPSN); ANDRA, a new agency responsible for long-term waste storage and disposal; and SGN, a COGEMA subsidiary which designs and builds fuel cycle plants. The Minister of Industry has the licensing responsibility. Additional information concerning the agencies and research institutes with major fuel cycle R\&D responsibilities is given below: 
Government Agencies

1. ANDRA, the National Agency for Radioactive Waste Management (Paris), develops, installs, and operates intermediate waste storage facilities and geologic repositories. ANDRA operates the La Manche waste storage center adjacent to the La Hague fuel reprocessing center.

2. BRGM, Bureau of Geological and Mineral Research (Orleans), is responsible for waste isolation R\&D.

3. IPSN, Institute of Nuclear Protection and Safety, is responsible for safety analysis for nuclear installations and development of regulations.

Nuclear Research Centers

1. Cadarache Nuclear Research Center (Saint-Paul-1ez-Durance located in the south of France, $65 \mathrm{~km}$ from Marseille) is responsible for MOX fuel fabrication and TRU waste treatment and disposal.

2. Fontenay-aux-Roses Nuclear Research Center (near Paris) is responsible for fuel reprocessing and waste treatment R\&D.

3. Establishment of the Vallée of the Rhône (Marcoule Centre at Bagnols-sur-Cèze) is responsible for fuel reprocessing and HLW immobilization R\&D.

NUCLEAR FUEL CYCLE

Fuels Production

France has extensive indigenous uranium resources and a mining and milling industry which had a design capacity of $3700 \mathrm{tU} / \mathrm{yr}$ in 1981.

Two major gaseous diffusion plants are located in France: the 400600 tSWJ/yr Pierrelatte facility; and Eurodif, a multinational project planned to reach a capacity of $10,800 \mathrm{tSWU} / \mathrm{yr}$ in 1982. The CEA is also building a pilot plant (50-100 tSWU/yr) to demonstrate a new French chemical exchange process which operates efficiently only for low enrichments. Startup is planned for 1983 . 
The Cadarache MOX plant makes fuels for the French LMFBRs. Capacity is $15 \mathrm{t} / \mathrm{yr}$ for LWR fuels and $5 \mathrm{t} / \mathrm{yr}$ for FBR fuels. In 1983, French $\mathrm{UO}_{2}$ fuel fabrication plants will have a total capacity of 1100 tu/yr. Spent Fuel Management ${ }^{(8)}$

Major resources in France are committed to industrial and development activities related to the transportation, storage, and reprocessing of spent fuels. Fuels are stored at the reactor site or in reprocessing plant pools. The CEA is concerned with developing shipping casks and conducts container qualification (fire, shock, and vibration) tests; experiments with wet shipments (to provide cooling); and risk studies at Fontenay-aux-Roses.

Reprocessing activities range from the development of equipment and processes for treatment of LWR and LMFBR fuels to the operation of large industrial plants. Major facilities include:

1. Industrial plants

- UP-1 (COGEMA, Marcoule) is designed for natural uranium, gasgraphite reactor fuels. Design capacity is 4.5-6 tHM/day.

- UP-2 (COGEMA, La Hague) was originally designed and constructed for natural uranium fuels from gas-graphite reactors, but now has a chop-leach head-end to allow treatment of LWR oxide fuels. Present capacities are 5 tHM/day for natural uranium metal fuels and $1.3 \mathrm{tHM} / \mathrm{day}$ for oxide fuels. Expansion of the oxide head-end to $4 \mathrm{tHM} / \mathrm{day}$ capacity is planned. COGEMA intends to reprocess gas-graphite fuels only at Marcoule in the future, leaving UP-2 for LWR fuels.

- UP-3 (COGEMA, La Hague) is a twin-line plant being built to handle LWR oxide fuels. The first line, UP-3A, is to start up in 1986 to service foreign customers. UP $-3 B$ will hand le domestic French fuels. Each line is sized at $4 \mathrm{tHM} / \mathrm{day}$. 
- PuRr (COGEMA, Marcoule) was planned for startup in 1989-1990, but the project is being re-evaluated and may not be pursued. The intent was to build a plant to treat MoX fuels from fast breeder reactors, at a throughput of $0.5 \mathrm{tHM} / \mathrm{day}$.

2. Pilot Plants

- SAP (CEA, Marcoule) is a $25 \mathrm{~kg} /$ day pilot plant used for process development in support of France's FBR fuel cycle program. It was recently equipped with a new head-end (TOR) designed to handle FBR fuels.

- AT-1 (COgEMA, La Hague) is a pilot-scale plant (1 kg/day) used to reprocess Rapsodie (LMFBR) spent fuels.

Waste Treatment $(10,25-27)$

National plans for waste management are:

- to vitrify a 11 HLW, provide interim storage for up to 100 years for the waste glass canisters in an engineered surface facility, then isolate in a suitable geologic formation

- to process liquid LLW by conventional techniques, producing a decontaminated stream which $c$ an be discharged into the environment and a radioactive concentrate which will be immobilized in bitumen, concrete, or a resin and then stored in a subsurface facility

- to place long-lived wastes into deep storage, at a suitable depth to shield them from human intrusion.

Since June 1978, COGEMA has successfully operated the AVM, a demonstration plant for vitrification of high-level wastes, using HLW from the reprocessing plant at Marcoule. Using a two-stage process (rotating tube calciner and induction-heated metal melter), AMM has a design capacity of 30 l/hr HLW feed, or one waste canister ( $360 \mathrm{~kg}$ glass) per day. Waste canisters are stored in an onsite underground vault. COGEMA has started construction of AVH, the first vitrification plant at La Hague, which will have a design feed rate of 
$49 \mathrm{l} / \mathrm{hr}$ HLLW. AVM-type plants are also to be installed at the Eurochemic site in Belgium, Windscale in Great Britain and perhaps the WAK reprocessing plant in Germany.

A number of nuclear energy centers are operating waste incinerators and pilot plants for incorporating non-high-level wastes in bitumen, concrete, or resins.

Development programs continue to emphasize, wnrk on the volume reduction and immobilization of transuranic wastes and fuel cladding hulls. Specific projects include americium recovery (Marcoule); washing and crushing of wastes for volume reduction (Cadarache); immobilization of TRU in concrete, bitumen, polymer, and glass waste forms; electrical melting of hulls, decontamination by treatment with molten glass and/or molten salts, and embedment in glass (Marcoule).

Bituminization processes and equipment for LLW and ILW have been developed and tested at The Cadarache, Marcoule, and Saclay Centers, and a pilot plant to immobilize reactor wastes in a thermosetting resin has been installed at the Chooz power station.

French investigators, primarily at Fontenay-aux-Roses, are working on improved methods for management of tritium and ${ }^{129} \mathrm{I}$ in fuel reprocessing plant effluents.

Geologic Waste Disposal $(7,25,27)$

French waste disposal policy is based on these basic assumptions: 1) a geologic repository must be used for a 11 radioactive wastes except low-level wastes which are essentially free of long-lived radionuclides; 2) a multibarrier scheme is necessary for a geologic repository; 3) borosilicate glass is a satisfactory waste form for high-level waste; and 4) until a repository is available, the vitrified high-level wastes can be stored safely in an engineered surface storage facility.

Although France has extensive salt, argillaneous, and crystalline rock formations, the geologic disposal R\&D program has emphasized the granite media, 
with support in this area from the CEC indirect action program. Officials continue to emphasize that France is investigating several types of formations, including seabed, and that no final decision has been made as to the type of geology. The crystalline rock R\&D program has followed two main lines of research.

1. an inventory of crystalline massifs and selection of two sites for extensive exploration and evaluation

2. study of radionuclide migration processes to evaluate the effectiveness of the geologic barrier.

Current and planned R\&D, managed and conducted primarily by the Paris School of Mines and the Bureau of Geological and Mineral Research, has these major features:

1. deep exploratory drilling into selected granite formations

2. development of a conceptual model of a suitable crystalline host-rock formation from reliable field data

3. improvements in selected investigative techniques

4. barrier development

5. assessment of the effect of the repository upon the geological environment

6. tests of the ability to backfill and seal shafts and boreholes against vertical upward movement of groundwater

7. construction of a test repository for TRU wastes

8. preliminary evaluation of salt and shale formations

9. active participation in the NEA Seabed Working Group.

France currently stores non-high-level wastes at the Centre de la Stockage de la Manche (near the La Hague plant) operated by ANDRA. Waste packages are stored on the surface, in concrete ditches, or in special shafts. Capacity is $300,000 \mathrm{~m}^{3}$. 
Major Milestones

- PURR reprocessing plant for FBR fuels (Marcoule)

Indef inite

- UP-3A reprocessing plant (La Hague)

- UP-3B reprocessing plant (La Hague)

- AVH waste vitrification plant (La Hague)

- Pilot plant repository for alpha wastes

1986

Indef inite

mid-1980s

1985

\section{GERMANY (FEDERAL REPUBLIC)}

Only about $45 \%$ of the energy requirements of the Federal Republic of Germany (FRG) are met from indigenous sources, and the country is heavily dependent upon $0 i 1$ and gas imports. In 1979, FRG plants generated 372 TWh of electrical power from solid fuels (48.2 Mtoe), gas (16.6 Mtoe), nuclear (9.7 Mtoe), oil (5.5 Mtoe), and hydro (3.9 Mtoe). (5)

The FRG has 11 LWRs (9.7 GWe) installed and 14 (17.2 GWe) under construction or on order. Two demonstration reactors, a HTGR, and a LMFBR are also under construction. The government has in the past been a strong advocate for the growth of nuclear power, promoting the construction of LWRs and working to develop advanced reactor technology as well as completely domestic fuel cycle capability. FRG industry has also been a major exporter of nuclear plants, fuel cycle services, and nuclear technology. In recent years, however, political opposition in West Germany has led to the government giving priority to conservation and indigenous coal development and utilizing nuclear power only as necessary to fulfill the incremental electrical capacity needs.

The FRG has a very powerful nuclear fuel cycle program. It includes worldwide uranium exploration (at least indirectly supported by the government), participation in international centrifuge enrichment projects, extensive $\mathrm{UO}_{2}$ and mixed-oxide fuel fabrication capability, the development of commercial fuel reprocessing and waste management facilities, and a strong FBR fuel cycle R\&D program. Commercial fuel cycle activities are, in general, characterized by the participation of strong industrial firms, with only ind irect government guidance. 
ORGANIZATION

The federal government coordinates the FRG nuclear programs; sponsors fuel cycle and waste management R\&D; and is charged by law to design, build, and operate any radioactive waste disposal facilities. The privately owned utilities are responsible for the fuel cycle, including spent fuel storage, reprocessing, and treatment of the associated wastes. The nuclear utilities are also to pay the costs of waste disposal by the government.

Nuclear plant licensing is the responsibility of the state in which the plant is to be sited. The Federal Ministry of the Interior (BMI) supervises state licensing procedures and may issue recommendations.

Development of fuel cycle and waste management technology is handled primarily by the following federal agencies, institutes, and companies:

Federal Agencies

1. BMFT, Federal Ministry for Science and Technology (Bonn), promotes and coordinates nuclear research and engineering.

2. BMI, Ministry of the Interior (Bonn), is responsible for atomic safety, radiation and protection, and supervision of the state 1 icensing procedures.

Research Institutes

1. BGR, Federal Institute for Geosciences and Natural Resources (Hannover), is studying geology-related effects in salt dome repositories, rock salt properties, rock mechanics, etc.

2. DHI, Geman Hydrographic Institute, is located in Bonn.

3. GSF/IfT, Society for Radiation and Environmental Research/Underground Storage Institute (Braunschweig), is responsible for providing the scientific foundations for safe underground storage of radioactive wastes. Major functions include studies of rock mechanics, geology, hydrology, and safety. One arm of this institute, the operating Department of Underground Storage, conducts R\&D operations at the Asse salt mine and laboratory studies at facilities in Braunschweig and Clausthal-Zellerfeld. GSF/IfT is also evaluating the use of the Konrad iron mine for low-level waste disposal. 
4. MI, Hahn-Meitner Institute for Nuclear Research (Berlin), is responsible for FRG's fuel cycle safety assessment project and for continuing work on the formulation and properties of high-level waste glasses.

5. KFA, Jülich Nuclear Research Center, is the principal West German facility for research, development, and demonstration of HTGR techno logy.

6. KfK, Karlsruhe Nuclear Research Center, has extensive R\&D programs in the areas of LWR spent fuel reprocessing and the treatment and conditioning of wastes from the LWR fuel cycle. The center is also the home of the CEC's European Transuranium Institute.

7. PTB, Federal Physical-Technical Institute (Braunschweig), by federal law has the assignment to design, license, and operate final disposal sites sucin as the Gorleben repository.

Private Industry

1. ALKEM GmbH (Hanau) is responsible for MOX fuels development and fabrication, and TRU waste treatment R\&D.

2. DWK, German Fuel Reprocessing Company (Hannover), was organized in 1977 by 12 utilities to provide spent fuel transport, storage, reprocessing, and waste management services for their nuclear power stations. Spent fuel reprocessing and waste management are the responsibility of three DWK divisions:

- WAK GmbH, Karlsruhe Company for Reprocessing of Nuclear Fuels (Leopoldshafen-Eggenstein, adjacent to the Karlsruhe Nuc lear Research Center) now has responsibility to manage fuel cycle R\&D for DWK and to operate the WAK reprocessing plant.

- KEWA, Kernbrennst off-Wiederaufarbe itungs-Gesel1schaft mbH (KEWA Nuc lear Fuel Reprocessing Company), Hannover. KEWA is the DWK engineering division.

- BLG, Gorleben Fuel Element Company, is to operate DWK's AFR spent fuel storage facility at Gorleben. 
3. NUKEM GmbH (Hanau) offers commercial fuel cycle and waste management engineering services and is currently involved with the design of the FRG PAMELA vitrification pilot plant and with the spent fuel disposal evaluation project.

4. Transnuklear GmbH (Hanau) is a subsidiary of NUKEM which provides spent fuel and waste transport services and is a partner with BNFL (UK) and Transnucleaire (France) in Nuclear Transport Limited.

\section{NUCLEAR FUEL CYCLE}

Several years ago, adequate provision for nuclear waste management became a precondition for issuing construction permits for additional reactors in West Germany. In response to this requirement, the FRG nuclear utilities set up the nuclear fuel reprocessing company (DWK), and the government initiated work on selection and characterization of geologic repository sites.

Current FRG strategy includes: 1) thorough evaluation of the final storage of spent fuels as an alternative to reprocessing; 2) indef inite storage of spent fuels at one or more AFRs, probably in dry storage casks, until the choice can be made between domestic reprocessing and final storage of unreprocessed fuels; 3 ) interim reprocessing of FRG fuels (2700 tonne) by COGEMA at La Hague; 4) construction of one or more small ( $350 \mathrm{t} / \mathrm{yr}$ ) reprocessing plants; 5) construction of a salt dome repository at Gorleben for HLW; 6) construction of interim storage facilities at Gorleben for LLW; and 7) use of the abandoned Konrad iron mine for non-TRU wastes, including facility decommissioning wastes. Fuels Production

West Germany has only limited indigenous uranium resources, but has an installed mining/milling capacity of $100 \mathrm{t} / \mathrm{yr}$, and the German company, Uranit mbH--a partner with British and Dutch companies in the URENCO consortium-plans to build a 400-tSWU/yr gas centrifuge plant at Gronau. Construction is expected to be complete in 1986 . 
West Germany's primary fuel development programs are conducted by ALKEM in facilities at Hanau and by KFA at Jülich. ALKEM, with a MOX fuels pilot plant rated at 3-5 t/yr, develops and demonstrates technology for fabrication of LWR and LMFBR fuels. KFA, assigned overall HTGR responsibility, develops and tests $\mathrm{TnO}_{2}-\mathrm{UO}_{2}$ fuels.

Spent Fuel Management $(8,28)$

The FRG is turning to a dry storage system for spent fuels, in which lowcost "Castor" malleable cast iron, fuel transport casks are to be used as longterm containers for fuel assemblies. Extensive R\&D has been done in developing fabrication technology and in securing a license.

Spent fuel storage: DWK plans for up to three 1500-t spent fuel storage facilities: one at Gorleben, one at Ahaus, and the third at an unannounced site. They are to utilize the dry storage concept.

DWK proposes to build several 350-t/yr fuel reprocessing plants. To handle the immediate spent fuel storage problem, DWK has contracted with COGEMA to have $1700 \mathrm{t}$ reprocessed at La Hague.

Studies of spent LWR and LMFBR fuel reprocessing continue at Karlsruhe where the following facilities are available:

1. KfK's Institute for Hot Chemistry, with extensive hot cell facilities for reprocessing studies

2. TEKO Hall, designed for large-scale cold tests of head-end and solvent extraction equipment and processes

3. the WAK pilot plant.

Thorium fuel reprocessing technology is the responsibility of KFA's Institute of Chemical Technology at Jülich, which has a $2-\mathrm{kg} / \mathrm{day}$ hot reprocessing pilot plant (Jupiter) under construction.

Waste Treatment (29)

HLW Vitrification $(10,30)$

DWK has selected the French AVM waste vitrification process for installation at the WAK reprocessing pilot plant at Karlsruhe. The company is also 
basing its license application for the waste treatment facility at the Hessen fuel reprocessing plant on the AVM process. The waste canisters are to be stored in air-cooled, underground interim storage facilities until they have cooled sufficiently to allow placement in the salt dome repository.

Although the French AVM process is the reference for FRG's proposed commercial-scale HLW vitrification plants, the FRG authorities want a back-up process based on domestic technology. Hence the country's HLW immobilization $R \& D$ program is based on the objective of providing a large-scale radioactive demonstration of a liquid-fed ceramic melter process, which has been studied at KfK for several years. The demonstration is to be achieved in a new pilot plant, PAMELA, under construction at the Eurochemic site in Mol, Belgium. PAMELA is to produce a borosilicate glass, either as marbles which can be embedded in a low-melting alloy or as glass blocks. Supporting process and equipment development studies are conducted at $\mathrm{KfK}$ and in Eurochemic laboratories, while product characterization work is the responsibility of the Hahn-Meitner Institüt.

The FIPS process, designed to vitrify thorium fuel cycle wastes for the HTGR program, has been developed at KFA, Jülich.

Treatment of Other wastes $(31-33)$

Other waste treatment studies include:

1. volume reduction of TRU wastes by washing, acid digestion, and pyrolysis (ALKEM, NUKEM, and KfK); an acid digestion plant, erected by KfK on Eurochemic premises in Belgium, started hot operation in early 1982

2. handling and packaging of cladding hulls (KfK):

- properties of hulls (e.g., heat generation, tritium release)

- immobilization of hulls in concrete

3. volume reduction of liquid wastes by evaporation or chemical tre atment

4. combustion and mechanical volume reduction of solids (Jülich and Karlsruhe) 
5. incorporation of .non-HLW in concrete, bitumen, and resins (Karlsruhe, NUKEM)

6. management of airborne effluents:

- in-plant control and storage (Jülich and Karlsruhe)

- cryogenic processes for noble gas recovery (Karlsruhe)

- ion implantation of krypton in a metal matrix (Karlsruhe).

Waste Disposal $(29,34)$

Since 1965, the FRG's efforts to develop geologic waste disposal technology have been focused on work at the Asse salt mine. The mine has been used for large-scale experimental disposal of low- and intermediate-level wastes. R\&D activities have included development of cavern construction tecinnology, testing of various techniques for placing waste containers in repositories, rock mechanics studies, in situ measurements of thermal and hydrologic parameters and safety analyses (BGR, GSF/IfT, and PTB). KfK and GSF/IfT are cooperating in a program to develop technology for the in situ solidification (in a cement matrix) of low- and intermediate-level wastes in a salt cavern. West Germany also intends to convert the Konrad iron mine (at Salzgitter) into an industrial repository for non-alpha-bearing wastes.

In the fall of 1980 , BMFT announced a major R\&D program to evaluate the technology for geologic disposal of spent fuel as an alternative to fuel reprocessing. KfK was assigned to set up an interdisciplinary group to manage the project. The program scope includes:

1. development of conditioning and packaging concepts, ranging from packaging complete assemblies to packaging assemblies after they have been chopped and degassed

2. studies of repository design, safety, canister retrievability, and potential repository sites.

HMI has the lead in a major West Germany program ( $\$ 12$ million spread over 4 years) to assess the safety of the post-reactor fuel cycle, including final disposal of wastes in salt. 
Major Milestones

- Complete site characterization at Gorleben

1985
After 1985

- Policy decision between domestic fuel reprocessing and spent fuel disposal

- Hessen fuel reprocessing plant

- PAMELA HLW vitrification pilot plant

- HOVA HLW vitrification plant for the WAK pilot plant

- Konrad iron mine repository

- Gorleben repository

1992

1986

1990

1985

1995

INDIA

With an estimated population of almost 700 million, India has a total installed electric generating capacity of only 29,000 megawatts. Forty to $45 \%$ of the total energy consumed in India still comes from firewood, cow dung, and agricultural wastes. India has indigenous coal and oil resources which are being exploited, but current projections indicate that by the year 2000, at least 45 million tonnes of oil will need to be imported each year and that $10-16 \%$ of the country's railroad traffic will be used for transport of coal.

India has five nuclear power reactors constructed (two 200-MWe BWRs and three 200- to 220-MWR PHWRs), for a total nuc lear capacity of 1.2 GWe, and construction has started on three additional PHWRs (220 MWe each). Design work is under way on a generation of 550-MWe PHWRs, and national plans call for building 12 of the larger model by the year 2000, for a total nuclear power capacity of 10 GWe.

Long-term nuclear strategy, as spelled out in 1954, envisages three steps: 1) operation of natural uranium reactors to produce power and plutonium; 2) construction of Pu-fuelled fast breeders to produce power, $\mathrm{Pu}$, and ${ }^{233} \mathrm{U}$ (from thorium); and 3) construction of ${ }^{233} \mathrm{U} / \mathrm{Th}$ breeders for power production. In support of step 2, a 40-MWt FBR test reactor is being built at Kalpakkam. India expects to have power-producing FBRs in service by the year 2000 .

Domestic self-reliance in reactor construction, heavy water production, and all phases of the fuel cycle is one of the government's major goals. $(35,36)$ 
ORGANIZATION

Atomic energy matters in India are administered by the Department of Atomic Energy, which includes the Atomic Energy Commission, the Nuclear Fue 1 Complex, and the various nuclear power stations. Nuclear research and development is administered by the Atomic Energy Commission and performed primarily by the Bhabha Atomic Energy Centre (BARC) at the Trombay site or one of BARC's satellite installations.

BARC was established in 1959 as a multidisciplinary facility for research and development. Located at BARC are four test reactors; radiochemistry and isotope 1 aboratories; an isotope production and processing unit; pilot plants for production of heavy water, zirconium, titanium, etc.; a thorium plant; a uranium metal plant; a fuel reprocessing plant; the Fuel Irradiation and Processing Laboratory; and supporting facilities. In addition to the Trombay installation, BARC has research laboratories at Guaribidanur and Kashmir; the Reactor Research Centre for Fast Reactor Development at Kalpakkam; and the Variable Energy Cyclotron at Calcutta.

NUCLEAR FUEL CYCLE

Fuels Production

India has a contract with the US to supply enriched uranium for the two BWRs at Tarapur, but uses domestic uranium for its heavy water reactors. Uranium mining/milling capacity is almost $200 \mathrm{t} / \mathrm{yr}$. Zircaloy components and $\mathrm{UO}_{2}$ fuels are fabricated at the Nuclear Fuel Center, Hyderabad (about $100 \mathrm{t} / \mathrm{yr}$ $\mathrm{UO}_{2}$ ), while MOX fuels have been produced on an experimental basis at Trombay and at the Reactor Research Centre at Kalpakkam.

Spent Fuel Reprocessing

Reprocessing of spent fuels was started in 1964 with the commissioning of a 0.1-0.15-t/day pilot plant at Trombay, near Bombay. Intended primarily to reprocess the fuel from a test reactor, the Trombay plant produced the plutonium used in India's nuclear weapons test. It was shut down in 1974, decontaminated, and prepared for future alterations to allow its continued use in reprocessing test reactor fuels. 
Based on the experience gained at Trombay, a 100-t/yr reprocessing $p 1$ ant has been built at Tarapur, to handle PHWR fuels and Tarapur's BWR fuels, and a second 100-t/yr plant is being designed for the Kalpakkam site. The Kalpakkam plant is to handle PHWR and FBR fuels. (35)

Primarily because of transportation problems, the reprocessing plants are to be situated adjacent to the power stations they will service, and other plants are to be built as needed.

A reprocessing laboratory has been established at Kalpakkam. Current emphasis is upon equipment development and testing.

Waste Treatment (37)

Liquid HLW is concentrated in evaporators, then stored in stainless steel tanks located in underground concrete vaults. Each tank is about $200 \mathrm{~m}^{3}$ in capacity and is provided with internal cooling coils to dissipate decay heat. This type of storage system has been in operation for the 1 ast 10 years, and no serious problem has so far been encountered.

Indian HLW solidification R\&D has focused on the Waste Immobilization Plant (WIP) at Tarapur. Based on a semicontinuous pot process developed at BARC, the WIP flowsheet provides for preconcentrating the HLLW feed, followed by calcination and melting in an Inconel 600 calciner-melter to form a borosilicate glass.

After 4-6 hr in the molten state, the glass is drained into a $304 \mathrm{~L}$ stainless steel storage canister which holds about $125 \mathrm{~kg}$ (45 l) glass. Two such canisters are emplaced in a secondary high-integrity mild steel container which forms the final storage unit. In the Immobilization Plant there are two furnace units which operate in a staggered operating cycle. Capacity is one canister per day. Construction was completed in 1981.

High-level waste glass canisters are to be stored in underground storage vaults cooled by natural convective air circulation, until they can be moved to a geologic disposal site.

A liquid waste treatment plant, with a two-stage decontamination facility using chemical treatment and ion exchange with vermiculite, has been in continuous operation at Trombay since 1966. Degraded solvent wastes are treated 
in a vacuum distillation unit for recovery of diluent and undegraded TBP. The residues are incorporated in bitumen. Intermediate-level liquid waste streams are also solidified by incorporating the waste salts in insoluble bituminous matrices. The solidified waste products are stored in suitably designed underground concrete trenches near the site of generation.

Waste treatment R\&D includes studies of:

1. TRU waste partitioning, conversion of TRU wastes into insoluble aluminosilicates by a hydrothermal process, and decontamination and densification of zircaloy cladding hulls (BARC)

2. solar evaporators for concentration of liquid effluents. Waste Disposal

India intends to develop a repository for high-level and TRU wastes. A geologic survey for potential repository sites has been conducted, and supporting R\&D is under way at BARC. According to early reports, igneous rock and sedimentary formations appeared to have the best potential. A late 1980 report indicated that a 3000-m deep gold mine had been selected as a repository site, and plans were being made for disposal of HLW at the 1000-m level. A research station is also being established near Kolar in the Karnataka State to assess the suitability of peninsular gneisses for use as a repository material.

$\underline{\text { ITALY }}$

Italy is heavily dependent upon energy imports with on ly 15-20\% of its energy needs being met from indigenous sources. In 1979, Italian plants produced 172.6 TWh of electric power from oil (22 Mtoe), hydro (10.5 Mtoe), solid fuels ( 3.5 Mtoe), gas (2.3 Mtoe), and nuclear ( 0.6 Mtoe). (5)

Italy has two BWRs (1.0 GWe), one PWR (247 MWe), and one Magnox GCR (150 MWe) installed as well as two BWRs (2.0 GWe) under contruction. The current national energy plan, adopted in October 1981, calls for spending $\$ 70.6$ billion during the rest of the decade for an additional 6000 MWe of PWR-based nuclear capacity and 6000 MWe of coal-fired capacity. Italy (through ENEL) has a one-third interest in Super Phenix, the international LMFBR project in France. 
Long-term Italian policy assumes domestic reprocessing of spent fuels, recycle of uranium and plutonium, vitrification and long-term (interim) storage of HLW, and eventual geologic disposal of the conditioned HLW.

The country has developed commercial capability throughout the fuel cycle, with investments in the Eurodif/Coredif enrichment plants, a strong capability in fabrication of plutonium (MOX) fuels for LWRs and FBRs, and reprocessing experience through the operation of small reprocessing pilot plants.

\section{ORGANIZATION $(a)$}

The Ministry of Industry has overall responsibility for nuclear energy matters with decisions subject to approval by Parliament. Italian organizations with major fuel cycle R\&D roles include the National Committee for Nuc lear Energy (CNEA); CNEA's Casaccia, Trisaia, and Saluggia centers; AGIP Nuc leare, a company with commercial interests in many aspects of the nuclear fuel cycle; and NUCLECO, a company formed to treat and dispose of low- and intermediate-level wastes.

The Casaccia Center, located in Rome, has a varied nuclear R\&D program. The Trisaia Center, at Rotondella in southern Italy, is the site of the ITREC Fuel Reprocessing $\mathrm{Pil}$ lot $\mathrm{Pl}$ ant and of clay repository studies. The Saluggia Center, located near Torino in northern Italy, is the site of the EUREX fuel reprocessing pilot plant, the construction of which was partly funded by Euratom.

NUCLEAR FUEL CYCLE

\section{Fuels Production}

Italy has reasonably assured uranium ore resources equivalent to 2400 tonnes of uranium and possible additional mineable resources of $2000 \mathrm{t}$. The startup of mining and milling operations at a rate of $170 \mathrm{tU} / \mathrm{yr}$ is planned

(a) The European Community has a Joint Research Center laboratory at Ispra in northern Italy. JRC-Ispra programs are considered in the International Relations section. 
for 1987. (2) The country owns a $25 \%$ interest in the Eurodif enrichment venture in France, and has $\mathrm{UO}_{2}$ fuel fabrication capability.

AGIP Nucleare is building a 14-t/yr plant at Rotondella to fabricate fast breeder $\mathrm{PuO}_{2} \mathrm{IUO}_{2}$ fuels for the Super Phenix FBR core, with startup scheduled for 1982 .

Spent Fuel Reprocessing

Italy has two pilot-scale reprocessing plants, EUREX and ITREC, and the construction of an industrial-scale plant is being evaluated by CNEN and AGIP Nucleare. The probable capacity of the industrial-scale plant is $1200 \mathrm{tHM} / \mathrm{yr}$. It may be located near EUREX (Torino area) or ITREC (Rotondella area). In the interim, limited quantities of Magnox fuel are being treated by BNFL at windscale.

The EUREX pilot plant at the Saluggia Center was initially designed for MTR fuels. EUREX now has a chop-leach head-end and capability for LWR oxide fuels. Capacity for MTR fuels is $30 \mathrm{~kg} / \mathrm{d}$ ay and for LWR oxides is $50-100 \mathrm{~kg} / \mathrm{day}$.

The ITREC pilot plant at the Trisaia Center has a chop-leach head-end and was designed to reprocess thorium-uranium fuel from Elk River under a joint program with the US. The plant's current assignment is FBR fuel reprocessing $R \& D$. Alternative fuel cycle techniques, including "coprocessing" to yield a mixed uranium-plutonium product stream, are under investigation. (5) Waste Treatment ${ }^{(7)}$

A HLW pot vitrification process, ESTER, has been developed at the Casaccia Center and subjected to radioactive tests in JRC-Ispra hot cells. Further testing is being done in a nonradioactive pilot plant (IVET-1) at the Trisaia Center, in preparation to build hot vitrification plants (IVET-2 and IVEX) at ITREX and EUREX, respectively. In the ESTER process, the waste stream is denitrated and concentrated, mixed with glass-making chemicals, and added to a metallic pot for calcination and vitrification. The glass is left in the melting pot for disposal. 
TRU waste treatment studies include development of a molten-salt incineration process (AGIP Nucleare), TRU waste washing techniques and facilities, and partitioning flowsheets.

Waste Disposal $^{(7)}$

Low-level waste is stored in drums, principally at the research centers and the power plants. Italy participates in the OECD Nuclear Energy Agency's sea disposal studies, but has not actually shipped any material to be dumped in the ocean.

The current Italian HLW disposal concept calls for a cooling period of 50-60 years for the HLW glass canisters before non-retrievable emplacement in a geologic repository. Italy has salt, rock, and clay formations, but the major emphasis has been placed on clay, which is found throughout the country. Italy's repository $R \& D$, supported in part by the CEC under their matching funds program, has included geologic exploration, heating experiments in clay beds, deep drilling at the Trisaia site, engineering development, and safety as sessments.

CNEN plans to carry out further tests at a quarry near the Casaccia Center and to set up an underground research laboratory at a depth of about $150 \mathrm{~m}$, using an existing mine, tunnel quarry, or steep natural slope for access.

\section{JAPAN}

Japan depends on imported fuels for about $85 \%$ of its total energy requirements. In 1979, Japanese plants produced 573 TWh of electrical energy from $0 i 1$ (60.3 Mtoe), hydro (20.6 Mtoe), nuclear (15.0 Mtoe), gas (13.5 Mtoe), and solid fuels ( 8.7 Mtoe). (5)

Japan has 11 BWRs ( 7.7 GWe), 10 PWRs ( 7.0 GWe), one GCR (0.16 GWe), and one HWR (0.2 GWe) installed. Six BWRs ( $5.8 \mathrm{GWe})$, five PWRs ( 3.9 GWe), and one LMFBR (0.3 GWe) are under construction. The Japanese government actively supports nuclear power as the primary means of reducing dependence upon foreign energy sources, although some of the opposition parties favor less dependence on nuclear. Siting problems are increasing and nuclear capacity forecasts have fallen. 
The government's strategy is to install LWRs for near-term power production; develop an advanced thermal reactor (ATR) based on the 165-MWe prototype FUGEN (heavy-water moderated, boiling light-water cooled) which started commercial operation in 1979; work toward commercial operation of fast breeder reactors, with the construction of a 300-MWe prototype, MONJU; and eventually depend heavily on fusion power.

The government also considers it essential that Japan build an independent commercial nuclear fuel cycle capability. To this end, the country is buying an interest in uranium mining ventures in other countries, including the US, and working toward commercial facilities for uranium conversion to UF 6 , uranium enrichment (by centrifuge), fuel fabrication, LWR and FBR spent fuel reprocessing, recycle of plutonium to ATRS and FBRS, and waste treatment.

\section{ORGANIZATION}

The government funds most of the nuclear R\&D, including fuel cycle and waste management programs, and is responsible for disposal of high-level waste. Industry is responsible for the commercial fuel cycle, for developing technology and industrial capability for disposal of LLW, and is to pay for HLW disposal on the basis of the principle that "the polluter pays."

Several government agencies and private companies have major fuel cycle and waste management responsibilities.

\section{Government Agencies}

1. The Japan Atomic Energy Commission (JAEC) and the Nuclear Safety Commission (NSC) advise the Prime Minister with regard to nuclear energy policy and nuclear safety and regulations, respectively.

2. The Science and Technology Agency (STA) was established to promote and administer research and development for the government. STA is the parent agency for PNC, JAERI, the Atomic Energy Board (which promotes the application of nuclear power in Japan), and the Nuclear Safety Board (which provides technical support for the regulatory processes). 
3. The Japan Atomic Energy Research Institute (JAERI) conducts nuc lear energy R\&D (fusion and HTR development, reactor safety research, and safety assessments), supplies radioisotopes, and trains nuclear scientists and engineers from outside the Institute. JAERI has headquarters in Tokyo. Its primary fuel cycle/waste management R\&D activities are centered at the Tokai and 0-arai Research Establishments, about $120 \mathrm{~km}$ northeast of Tokyo.

4. The Power Reactor and Nuclear Fuel Development Corporation (PNC) develops and demonstrates new types of power reactors and fuel cycle processes, equipment, and techniques. PNC is in charge of developing a HLW solidification process and building a HLW treatment pilot plant at Tokai-mura. The corporation is also developing technology for uranium enrichment, nuclear fuel fabrication, and fuel reprocessing. PNC has its headquarters in Tokyo and major installations at Tokai-mura and 0 -arai-machi.

5. The Ministry of International Trade and Industry (MITI) has administrative responsibility for the management of natural resources and energy, as well as Japanese international trade and industry. MITI maintains governmental oversight of commercial nuclear power and nuclear fuel cycle activities.

Industrial Organizations

1. The Radioactive Waste Management Center (RMC), sponsored by a number of utilities and manufacturers, is responsible to develop systems for sea dumping and land isolation of low-level wastes; provide sea dumping and land isolation on a contract basis; and provide associated environmental monitoring and safety analyses services.

2. The Japan Nuclear Fuel Services Co. (JNFS) was organized by a large group of utilities and manufacturers to build and operate commercial reprocessing facilities and to provide for storage of the HLW glass which will be returned to Japan by foreign reprocessors.

3. Many private companies participate in waste management R\&D, under contract with one of the government agencies, RMC, or JNFS. 
NUCLEAR FUEL CYCLE $^{(7)}$

Fuels Production

Japan mines and mills about 30 tU/yr in domestic facilities and operates a $\mathrm{UF}_{6}-\mathrm{UO}_{2}$ conversion plant rated at $200 \mathrm{t} / \mathrm{yr}$. The initial stages of a gas centrifuge plant have begun operation at the Ningyo Pass mine site. Full operation (75 tSWU) with 7000 machines started in 1981 while expansion to $1000 \mathrm{tSWU} / \mathrm{yr}$ by 1985 is planned.

Japan relies on private industry to fabricate uranium fuels and on PNC for development and fabrication of MOX fuels. PNC's Plutonium Fuel Fabrication Facility (PFFF) has two fabrication lines-a FBR fuel line with a 15-kg MOX/day capacity and a HWR fuel line with a 10-t/yr capacity.

Spent Fuel Management

The Tokai-mura reprocessing pilot plant ( $0.7 \mathrm{tHM} / \mathrm{day})$ has been licensed for "regular operation," but Japan will depend on foreign fuel reprocessing services by COGEMA (France) and BNFL (UK) until the first commercial plant is built in Japan, scheduled for 1990. That is also the year in which the foreign reprocessors are scheduled to start returning reprocessing wastes to Japan.

A major milestone was reached in the fall of 1981 with successful operation of FUGEN using $\mathrm{PuO}_{2}-\mathrm{UO}_{2}$ (MOX) fuel assemblies fabricated in Japan and containing plutonium recovered from spent LWR fuels in the Tokai-mura fuel reprocessing plant. Thus the plutonium-uranium fuel cycle has been closed in Japan.

With her major nuclear facilities located on or near the nation's coastlines, and plans to have $3800 \mathrm{t}$ of spent fuel processed in England and France, Japan is emphasizing the development of marine transport technology and capability. Two major programs are under way:

1. drop impact, fire, and deep-water inmersion tests of full-scale transport package and models (STA)

2. a joint study with the US on the use of a mid-Pacific island site for long-term storage of spent fuels. 
Japanese reprocessing facilities and activities include:

1. Tokai-mura plant (PNC), a nominal 0.7-t/yr Purex plant for LWR oxide fuels which started operations in late 1977, but had a series of equipment problems. The process includes a chop-leach head-end and a mixer-settler solvent extraction system.

2. An industrial two-line, 6-tU/day reprocessing plant, which is to be built and operated by JNFS. Startup is planned for 1990.

Japan has an extensive reprocessing R\&D program, directed to support the construction of a commercial-scale plant for LWR fuels and to develop a process for FBR fuels. The program focuses on head-end technology; development of solvent extraction equipment for high-exposure, short-cooled fuels; plutonium/uranium partitioning; and off-gas control.

Waste Management $(38,39)$

Waste management scenarios assume:

1. spent fuel storage for 180 days to one year after discharge, followed by reprocessing

2. liquid HLW storage for five years, followed by vitrification

3. engineered storage of HLW glass canisters at the vitrification plant for at least 30 years

4. geologic disposal of HLW, probably in a granite, diabase, shale, tuff, or limestone formation

5. long-term interim storage of intermediate-level wastes

6. engineered storage of TRU wastes, pending the government's decision concerning their disposal--a partitioning/transmutation option is being evaluated

7. sea disposal of LLW packages, if this becomes politically acceptable; otherwise, land disposal--probably by shallow land burial. 
Waste Treatment

Current high-level waste studies are aimed at 1) having PNC's Vitrification Pilot Plant in place by 1987, ready to hand le HLW from the Tokai Works fuel reprocessing plant, 2) demonstrating a similar process for solidifying HLW from FBR fuels, and 3) preparing to receive solidified HLW from the overseas reprocessors in France and England.

Several alternatives for solidifying $H L W$ have been scouted in Japan, and work is continuing on the evaluation of several alternative waste forms. PNC has chosen the production of borosilicate glass in a ceramic melter for the first-generation process.

During 1981, PNC completed construction on a major new R\&D facility at the Tokai site, the Chemical Processing Facility (CPF). The building has two hot cell lines, which have about $200 \mathrm{~m}^{2}$ of floor area: 1) line $A$ is designed for studies of the application of the PUREX process to irradiated FBR fuels; 2) line $B$ is equipped to solidify HLW produced in Line $A$ and to characterize the waste products.

With responsibility for fuel cycle and waste management safety assessment, JAERI is concerned with evaluating high-level waste form behavior under transport, storage, and disposal conditions. Preparations are being made to start tests in the new waste Safety Testing Facility (WASTEF) at Tokai in 1982. WASTEF has five hot cells equipped to vitrify radioactive wastes, weld and store waste canisters, and take and characterize samples of glass logs. Other HLW management studies include: metal matrix waste form evaluation (Mitsubishi Metals Corporation), canister welding (Kobe Stee1), storage of HLW canisters (Kobe Stee 1), and partitioning of HLW (JAERI).

PNC is sponsoring the development of varied technology for the new Plutonium Waste Treatment Facility: acid digestion; microwave melting of non-combustible residues; electroslag melting; and compaction of cladding hulls. JAERI is studying incinerator technology.

JAERI has a 30- $/ \mathrm{hr}$ bituminization plant at 0-arai for low-level waste, and PNC plans to build a similar 200-l/hr plant. Incinerators for combustible solids are in service at Tokai and 0-arai. Increasing attention is being paid 
to technology for volume reduction immobilization and disposal of low-level wastes: microwave melting of incinerator ash and LWR coolant sludge (Kobe Stee 1); acid digestion of power station waste (JGC Corporation and JAERI); plasma arc melting of noncombustible wastes (Daido Stee 1); fixation in resins and bitumen; and containment packages for sea or shallow land disposal (JAERI and RMC).

Installation of an offgas treatment facility for PNC's Tokai-mura fuel reprocessing plant was completed in early 1982. The plant includes cryogenic distillation components for the recovery and separation of xenon and krypton.

Japanese companies are investigating a number of other avenues to separation and containment of krypton-85: porous palladium membranes for noble gas recovery from reactor offgas (Mitsubishi), charcoal adsorption systems for reactor plant offgas (Hitachi), and zeolite encapsulation and charcoal adsorption for immobilization of krypton (Kobe Steel). (26)

Geologic Waste Disposal

The Japanese goal is to have a geologic repository ready for operation by about 2020. Supporting research and development is planned as follows:

Phase 1. research on potential geologic formations; planning for a facility to study waste-rock interactions; studies of seismic activity (1976-1985)

Phase 2. research on candidate formations; geologic characterization of deep underground conditions for selected small areas; rock properties tests (1986-1995)

Phase 3. in situ tests with a simulated waste package; nuclide migration tests; monitoring tests; canister handling technology; facility design studies

Phase 4. in situ studies with actual waste canisters; selection of a repository site

Phase 5. construction of the repository and trial disposal of HLW canisters until final disposal is achieved. 
The government is responsible to select candidate formations and test sites, provide impact assessments, and establish the disposal system. PNC is in charge of implementing the R\&D for each phase, including test activities, construction of test facilities, and trial disposal. Safety evaluations are a JAERI responsibility.

Major Miletones

- HLW solidification pilot plant (PNC)

- Commercial reprocessing plant for LWR fuels

- FBR fuel reprocessing pilot plant

- HLW solidification commercial plant

- Return of HLW from COGEMA and BNFL

- Experimental sea-dumping of LLW

- Selection of candidate geological or seabed

$\sim 1995$ repository formations

- Selection of repository test site for in situ

$\sim 1990$

$\sim 1982$ or later

$\sim 1985$ test with a simulated waste package

- Selection of demonstration site for in situ test with actual waste package

- Startup of disposal site

$\sim 1995$

$\sim 2005$

After 2015

\section{KOREA (REPUBLIC OF KOREA)}

The Republic of Korea has major deposits of anthracite coal but no indigenous coal or gas and very limited hydroelectric resources. Primary energy consumption was 41.4 Mtoe in 1981, fueled heavily by imports (69\%), and rising rapidly. Electrical generation capacity the same year was 10 GWe (12\% hydro, $82 \%$ fossil, and $6 \%$ nuclear). $(19,40,41)$

NUCLEAR POWER POLICY $(19,40-42)$

Korea plans to meet its rapidly increasing electrical power demand with both nuclear and coal generation plants. The country has one PWR (0.56 GWe) installed, seven PWRs (6.2 GWe) and one PHWR (0.63 GWe) under construction; and four more PWRs planned. Installation of a FBR in the late 1990s is also being considered.

Nuclear energy self-sufficiency is a national goal, and fuel cycle capability is being developed. Long-term planning assumes that either AFR spent 
fuel storage or domestic reprocessing will be required by the early 1990s. In the event the reprocessing option is selected, the plutonium will be recycled to a FBR or to thermal power stations.

\section{ORGANIZATION}

Nuc lear matters in Korea are handled by the Atomic Energy Commission and the Atomic Energy Board, within the Ministry of Science and Technology, Seoul; the Korea Advanced Energy Research Institute (KAERI), Seoul; the KAERI Daeduk Engineering Center, Daeduk Danji, and the Korea Electric Power Corporation.

\section{NUCLEAR FUEL CYCLE}

Fuels Production (42)

Korea has indigenous thorium and low-grade uranium ores, and is building a 3-t/day $U_{3} 0_{8}$ pilot plant for uranium extraction. A 100-tU/yr uranium conversion plant (UF $6 \rightarrow U 0_{2}$ ) was completed in 1982, a 10 -tU/yr fuel fabrication pilot plant has been operating since 1978, and plans are being made to build a 200-t/yr fuel production plant.

Spent Fuel Management

Energy planners expect that storage capacity for spent fuel will become inadequate during the period 1992-1997, and a major study has been started to evaluate the alternatives. Options under consideration include permanent storage of spent fuels, reprocessing with recycle to thermal reactors, and recycle of plutonium to FBRs. (KAERI and Korea Electric Power Corporation). Waste Management

A waste treatment facility to deal with various radioactive liquid and solid wastes is to be completed in 1983.

\section{MEXICO}

Mexico has large hydrocarbon fuel reserves, and oil and gas provide almost $90 \%$ of Mexico's primary energy supply; coal and hydropower make up the rest. 
In 1978, Mexican plants produced 53 TWh of electric power, from hydropower (16 TWh), geothermal sources ( $0.6 \mathrm{TWh})$, and $0 i 1$ and gas $(36.4 \mathrm{TWh}) .(7,43)$

Mexico has two 650-MWe BWRs under construction, scheduled for completion in 1984 and 1985. The government has set a target for the end of the century of 20 GWe installed nuclear power and has recently solicited bids for a new 2400-MWe station.

The country has also started to develop extensive uranium resources (550 tU mined in 1981), has an active program to develop improved technology for management of LLW and ILW from reactors and other sources, and appears to be interested in obtaining enrichment and fuel recycle technology from other countries.

\section{ORGAN IZATION}

Until 1978, Mexico's nuclear policies were carried out by the National Institute of Nuclear Energy (INEN). At that time, INEN was split three ways to make the National Atomic Energy Commission, a state company charged with exploration and exploitation of national reserves (URAMEX), and a National Nuc lear Research Institute (ININ) charged with R\&D. Nuclear power plants are owned and operated by the Federal Electricity Commission (CFE).

\section{NUCLEAR FUEL CYCLE}

Mexico is reportedly building several fuel cycle R\&D facilities at the Salazar Nuclear Center: a reprocessing pilot plant; a plutonium oxide production and storage pilot plant; a mixed-oxide fuel fabrication pilot plant; and a plutonium scrap recovery laboratory.

The nuclear wastes which have been generated in Mexico to date, chiefly low-level materials from users of radioisotopes, are disposed of in a repository owned and operated by the federal government. The repository is located at Maquisco in the state of Hidalgo. ININ is working to design and build a demonstration plant to package waste from hospitals and laboratories. 
THE NETHERLANDS

In 1979, energy production in The Netherlands exceeded demand by about seven percent, heavy oil imports being roughly compensated for by gas exports. In coming years, oil and coal imports are expected to rise significantly while gas exports decline. In 1979, Dutch plants produced 53.8 TWh of electrical power from gas (6.3 Mtoe), oil (4.8 Mtoe), nuclear (0.9 Mtoe), and solid fuels $(0.7$ Mtoe) $)$ (5)

The Netherlands has a 50-MWe BWR and a 445-MWe PWR and is involved in FBR research through participation in the SNR-300 project in West Germany. In 1975 the Dutch government approved plans for three new 1000-MWe nuclear facilities and expansion of the Almelo uranium enrichment plant from 225 to $1250 \mathrm{tSWU} / \mathrm{yr}$. However, subsequent government changes and adverse public opinion have repeatedly delayed furtherance of these plans. The government has called for resolution of waste management questions before deciding on further nuclear power plants, and in late 1980 initiated a public information campaign and debate on energy policy in general in order to gauge public feeling before making any decisions about nuclear power.

ORGANIZATION

The Ministry of Economic Affairs, Ministry of Public Health and Environmental Control, and the Ministry of Social Affairs have overall responsibility for nuclear energy matters; their decisions are subject to approval by Parliament. Other organizations with major fuel cycle and waste management roles include the Netherlands Energy Research Foundation (ECN) which operates the Petten Research Center and is responsible for disposal of Holland's low-level wastes; the Geologic Survey of the Netherlands; and KEMA, a research and engineering company which is concerned with technology for the volume reduction and storage of reactor station wastes. 
NUCLEAR FUEL CYCLE

Holland has no indigenous uranium resources, but is a full partner with France and the United Kingdom in the Urenco uranium enrichment consortium and has a 200-tSWU enrichment plant operating at Almelo. Reactor fuels are bought from foreign suppliers.

The country participated in the Eurochemic fuel reprocessing project and has contracted to have spent fuel from the two Dutch reactors reprocessed in France and England.

WASTE MANAGEMENT $(7,44,45)$

ECN is the authorized collection agent for radioactive wastes and is responsible for integration of the country's waste management R\&D. Reactor wastes are conditioned at the reactor site, institutional wastes at Petten--by embedding in cement. These materials are dumped into the sea under the surveillance of the $O E C D / N u c l e a r$ Energy Agency. On behalf of the nuclear power plant operators, KEMA is studying techniques for volume reduction of combustible wastes.

Recent contracts for reprocessing of Dutch spent fue 1 require that the vitrified HLW be returned to The Netherlands for disposal.

In 1979, the government submitted a report to Parliament which indicated that radioactive waste can be stored safely in underground salt domes in stateowned property in the northeastern region of the country. Plans were made to drill exploratory holes, about $500 \mathrm{~m}$ deep in salt domes under state-owned property, but these $p l$ ans have been indefinitely deferred. Plans also exist to examine the possibility of constructing a repository in a salt diapir below the seabed. The Netherlands is participating in the NEA Seabed Working Group studies, and techniques for interim storage of spent fuel elements and solidified HLW are being investigated.

With CEC financial support, the Dutch are working in several areas of geologic waste disposal technology: theoretical studies of thermal effects in salt dome repositories; measurement of distribution coefficients of various radionuclides in various soil samples; hydrogeologic evaluations; and safety assessment. 


\section{PAKISTAN}

Pakistan's known conventional energy resources (oil, gas, and coal) are extremely 1 imited, totaling only $1.2 \%$ of the world per capita average. Hydroelectric power generation potential is estimated at 18-25 GWe, but only about one-third of this is situated where it can be developed economically. Fuel imports are high (85-90\%). In view of these factors, the government has taken the position that nuclear power will have to provide an important share, 50\% or more, of future energy demands.

Currently Pakistan operates only one power reactor--a 137-MWe CANDU supplied by Canada--which went on-line in 1972. Plans for the future call for 24 reactors (16 GWe), chief ly LWRs, to be operational by the year 2000 .

Another Pakistan objective is to develop a complete domest ic fuel cycle, with plants for refining uranium ore, enriching uranium, fabricating fuel, and reprocessing spent fuel.

\section{ORGANIZATION}

Nuclear matters are organized and controlled by the Pakistan Atomic Energy Cominission in Islamabad. The Pakistan Institute of Science and Technology in Rawalpindi has a small laboratory-scale reprocessing facility.

\section{NUCLEAR FUEL CYCLE}

Pakistan plans to set up a nuclear complex including a reprocessing plant and eight power plants at the Chashma site on the Indus River in Mianwali District. A fuel fabrication plant started operations there in 1980, and construction is reportedly proceeding on the $300-\mathrm{kg} / \mathrm{d}$ ay reprocessing $\mathrm{plant}$.

\section{SOUTH AFRICA}

South Africa has large coal and uranium resources, which are being exploited, but depends upon imports for oil supplies. Expansion of electric power production from 20 GWe (1982) to about 70 GWe (2000) is planned, the principal increase coming from coal burning plants. ${ }^{(47)}$ 
South Africa has two PWRs (1.8 GWe) under construction, with operation scheduled to start in 1983 and 1984, respectively. In the past, the government has been a vigorous supporter of a major nuclear power program for the country, but the management of the Electricity Supply Commission of South Africa currently appears lukewarm toward nuclear and rules out a large program.

\section{ORGANIZATION}

Principal South African nuclear organizations are 1) the South African Atomic Energy Board (AEB), which reports to the Ministry of Mineral and Energy Affairs and is responsible for nuc lear regulatory matters, development of a waste disposal site, and R\&D on the use of nuclear energy in electricity generation, agriculture, industry, and medicine; 2) the Electricity Supply Commission of South Africa (ESCOM), which owns and operates the power generating plants; 3) the Nuclear Fuels Corporation of South Africa; and 4) the Uranium Enrichment Corporation of South Africa (UCOR).

NUCLEAR FUEL CYCLE $(2,48)$

The country has reasonably assured uranium resources of 356,000 tonnes and an expanding mining/milling capability (7300 t/yr, 1981; 10,700 t/yr, 1985). In addition, South Africa has developed its own uranium enrichment process, using a vortex tube concept, and UCOR is operating an enrichment pilot plant. Construction of a semi-industrial scale plant (300 tSWU/yr) is scheduled for completion in 1986-1987. UCOR also has a small UF 6 conversion plant in operation and plans a significantly larger facility for operation by 1984-1985. (48) Eventualiy, the nation will be dependent upon foreign fuel suppliers only for fabrication and, if required, could develop fabrication capabi lity.

The country has no plans for spent fuel reprocessing, but plans are being made for treatment and disposal of reactor wastes. Spent resins will be mixed with concrete and encapsulated in thick-walled concrete drums. The waste will remain at the Koeberg reactor site until the AEB has a disposal area ready. Liquids containing extremely low residual radioactivity will be discharged into the Atlantic Ocean. 
Imports account for about $70 \%$ of Spain's total energy requirement, with imported oil a major factor. In 1979, Spanish plants produced 105.7 TWh of electrical energy from hydro ( 11.3 Mtoe), oil (7.1 Mtoe), solid fuels (6.0 Mtoe), nuclear (1.5 Mtoe), and gas (0.2 Mtoe). ${ }^{(5)}$

Spain has one BWR (0.44 GWe), two PWRs (1.08 GWe), and one GCR (0.48 GWe) installed, and seven LWRS ( $5.5 \mathrm{GWe}$ ) under construction. The current energy plan emphasizes the use of coal, but also calls for 12.4 GWe installed nuclear capacity by 1990. Although heavily dependent upon foreign fuel cycle services, including spent fuel reprocessing by COGEMA and BNFL, the nation is moving to reduce this dependence through a number of actions: exploration for uranium, purchase of an $11 \%$ interest in Eurodif (uranium enrichment consortium), construction of a fuel fabrication plant and a central AFR spent fuel storage facility, and long-range plans for commercial reprocessing. (7)

ORGANIZATION ${ }^{(7)}$

Nuclear activities in Spain are controlled by the government through the following agencies:

- Junta de Energía Nuclear, JEN, is primarily a nuclear energy R\&D organization, with headquarters and a laboratory (Juan Vigon National Nuclear Energy Center) in Madrid. JEN is building a new research center at Soria, north of Madrid, for nuclear physics studies and for projects related to commercial nuclear power, e.g., spent fuel examination, waste treatment studies, and potentially a pilot-scale reprocessing facility.

- Empresa Nacional del Uranio SA, ENUSA (Madrid), owned $60 \%$ by the government and $40 \%$ by seven private utilities, has the task of providing nuclear fuel and fuel cycle services for the Spanish nuclear industry.

- Consejo de Securidad Nuclear, CSN--Council of Nuc lear Safety, was established in 1980 to handle siting, licensing, plant inspections, and environmental protection matters for the government. 


\section{NUCLEAR FUEL CYCLE}

\section{Fuels Production}

Spain has reasonably assured uranium resources of about $16,000 \mathrm{t}$ and by 1985 expects to have increased mining/milling capacity to $600 \mathrm{t} / \mathrm{yr}$. The country is also preparing for domest ic fuel fabrication, with a 600-t/yr plant under construction.

Fuel Cycle and Waste Management R\&D

JEN and the Spanish utilities are applying a modest level of effort in a number of areas:

1. Interim storage of spent fuels. This includes studies of AFR storage, techniques to increase the capacity of reactor pools, and the behavior of high-exposure fuels in pool and air storage.

2. Spent fuel reprocessing. JEN operated a small fuel reprocessing plant at the Juan Vigon Center for a few years to reprocess spent MTR fuels and plans to build a 2-t/yr pilot plant in the Soria Center.

3. Waste treatment. JEN has done limited laboratory-SCale R\&D on a variety of techniques for HLW solidification and has, at Juan Vigon, a pilot waste incinerator, a liquid waste treatment plant, a facility for sorting and compacting solid wastes, and a small installation to generate non-active glass.

4. Waste disposal. Spain hopes to develop a repository for high-level and other wastes and plans to start up a pilot repository by the late 1980s. For several years Spain has stored non-HLW drums in an abandoned iron mine located in the Sierra Morena. A search is being made for other repository sites and supporting R\&D is in progress.

5. Decommissioning of nucelear facilities. 


\section{SWEDEN}

Sweden's energy situation is very difficult, considering its dependence on imports ( $57 \%$ in 1979); its high level of energy consumption; and its lack of indigenous coal, oil, or gas. In 1979, Swedish plants produced 92.4 TWh of electrical power from hydro (13.5 Mtoe), nuclear (4.5 Mtoe), and oil (1.8 Mtoe). (5)

Sweden has seven BWRs ( 4.7 GWe) and two PWRs ( 1.7 GWe) installed. Two BWRs (2.1 GWe) and one PWR (0.9 MWe) are under construction and will complete the planned Swedish complement of 12 reactors. Under current energy policy, no additional power reactors of any type are to be built, and each of the reactors in service is to be decommissioned after 25 years' operation. Thus, the present goal is to shut down the last nuclear power plant by the year 2010 .

Present fuel cycle plans allow for either of two schemes: reprocessing of spent fuel by foreign reprocessors, BNFL and COGEMA, or disposal of unreprocessed spent fuels. In either case, disposal is to be accomplished in a granite repository.

\section{ORGANIZATION}

Under the provisions of a 1981 law, the primary responsibility for disposing of radioactive waste was placed on the nuclear power utilities. This responsibility extends to research and development and to erection and operation of facilities for handling and storing reactor wastes, spent fuel, and reprocessing wastes. The utilities have commissioned the Swedish Nuclear Fuel Supply Company (SKBF), which was organized by the utilities in 1973, to handle these duties. One of the SKBF departments, KBS, is responsible for radioactive waste management R\&D. Governmental oversight of SKBF waste management work is provided by a new national agency, the National Board for Spent Fuel.

SKBF also represents the utilities in the procurement of uranium and of fuel cycle services.

Other organizations with fuel cycle responsibilities include ASEA-Atom, which manufactures fuels and reactor components and systems; AB Energiteknik, 
the national energy R\&D facility located at Studsvik; the Swedish Nuclear Power Inspectorate (licensing of facilities); and the National Institute of Radiation protection. Laboratories at several universities and technical institutes are quite involved in waste treatment and disposal studies. $(7,49,50)$

NUCLEAR FUEL CYCLE

Fuels Production

Sweden has indigenous uranium resources estimated at 300,000 tU, but they occur in low-grade shales, and uranium mining is not considered economically or politically feasible at the present time. Hence, the nuclear power companies depend upon foreign sources for their uranium and their enrichment services. Fuels for Swedish-built reactors are fabricated by ASEA-Atom.

Spent Fuel Management

Sweden has not yet announced a decision between reprocessing and terminal disposal of their spent fuels. Contracts have been signed for BNFL and COGEMA to treat fuels from some of the Swedish power stations for a time, but the country may eventually choose the fuel disposal option. In order to provide for this contingency, and to protect against delays in the foreign reprocessing program, SKBF is building an AFR spent fuel storage facility (CLAB). Located near the Oskarshamn reactor station on the east coast, CLAB is to have two fuel storage pools, each sized for $1500 \mathrm{tU}$. It is being excavated from a granite formation, is located about $100 \mathrm{ft}$ below the surface of the ground, and is to be operational in 1985. A special ship is being built for SKBF to transport spent fuel from the other reactor sites to 0skarshamn and from Oskarshamn to COGEMA (France) for reprocessing.

Conditioning of spent fuels to prepare them for disposal and their longterm behavior under disposal conditions are being studied by ASEA-Atom and at the Studsvik research center. $(7,48,49)$

Waste Treatment

Sweden must dispose of reactor waste and waste from foreign fuel reprocessing operations. Various sites are studying waste treatment techniques, with design studies of methods for cutting and packaging reactor hardware; 
evaluation of alternatives for volume reduction of combustible wastes; the use of zeolites and titanates to improve reactor waste treatment; actinide fractionation; development of common waste conditioning techniques--embedment in cement, bitumen, or resins; compaction and conditioning of fuel cladding hulls and other suitable materials by hot isostatic pressing; and decontamination and decommissioning tests.

Laboratory studies of techniques for immobilizing HLW calcine have been conducted at Studsvik (hot pressing and encapsulation in graphite) and by ASEA-Atom (hot isostatic pressing and encapsulation in an alundum container). Spent Fuel and Waste Disposal $(7,49,50,52-54)$

SKBF plans to build two repositories, both in granite:

1. A storage facility for intermediate-level wastes such as reactor and TRU wastes and discarded reactor components. This would be placed about $50 \mathrm{~m}$ below the seabed, at a site $1400 \mathrm{~m}$ offshore from the Forsmark nuclear station.

2. A deep repository for either spent fuels or the high-activity wastes from reprocessing which are to be returned to Sweden by the reprocessor. Waste emplaced in this facility would be about $500 \mathrm{~m}$ below the surface and surrounded by a backfill mixture of sand and bentonite.

The deep disposal concept calls for interim storage of spent fuel, contained in a thick copper canister, in the CLAB facility for 40 years. The vitrified HLW would be encapsulated in thick lead canisters encased in titanium, then stored for 30 years in an air-cooled facility before emplacement in the repository.

The SKBF fuel handling and waste disposal plan was worked out in a crash program conducted by KBS in 1977-1978. It has been accepted by the government as satisfying the requirements of the 1977 Stipulation Law which links the start-up of new nuclear power plants with the demonstration of an "absolutely safe and final" method for disposing of radioactive wastes. 
Exploratory drilling is now being done to locate a suitable site for the deep repository. An extensive R\&D program, now managed by KBS, is moving ahead on many fronts:

1. HLW glass properties and durabilities in expected repository environments

2. corrosion of prospective canister materials: titanium and alumina for HLW glass; copper and alumina for spent fuels

3. the properties of bentonite and bentonite/quartz mixtures when used for barrier materials

4. techniques for borehole, shaft, and rock joint plugging and sealing

5. rock mechanics and seismotectonics

6. migration and transport of radionuclides away from the waste or spent fuel canister after emplacement in the repository

7. geology and hydrology

8. disposal system safety.

KBS is using the Stripa mine in Sweden for in situ tests, which are now cosponsored by several other countries and coordinated by the OECD Nuclear Energy Agency.

Major Milestones

- CLAB AFr facility for spent fuels

- Repository for reactor wastes

- HLW repository site selection

- HLW repository operational

- Interim HLW dry storage facility

$$
\begin{array}{r}
1985 \\
1989 \\
2000 \\
2020-2050 \\
1990
\end{array}
$$

\section{SWITZERLAND}

Switzerland is heavily dependent on imported oil, which provides $55-60 \%$ of the total primary energy requirement. The country current ly has abundant hydropower and is a major exporter of electricity. However, it appears that most sources of hydropower have been developed, and the nation cannot look to 
this source for energy growth. In addition, the country is very concerned with environmental matters, and there is major public opposition to nuclear power. In 1979, Swiss plants produced 45.5 TWh of electrical energy from hydro (7.0 Mtoe), nuclear (2.9 Mtoe), and oil $(0.3$ Mtoe). (5)

Switzerland has one BWR (320 MWe) and three PWRs ( $1.6 \mathrm{GWe}$ ) installed, one BWR (940 MWe) under construction, and two BWRs (2.1 GWe) planned but not yet approved by the government. Long-range plans call for as many as nine nuclear power stations.

There are no fuel cycle capabilities, and none are planned. Hence, the Swiss utilities are entirely dependent upon foreign suppliers for fuels and reprocessing services.

\section{ORGANIZATION}

Two agencies in Switzerland have the major roles in fuel cycle and waste management R\&D: the Federal Institute for Reactor Research (EIR) at Wurenlingen, and the National Cooperative Association for the Storage of Radioactive Wastes, known either as NAGRA (German acronym) or CEDRA (French acronym). EIR and all nuclear activities are controlled by the Department of Interior. NAGRA was formed by a coalition of private and governmental interests to get a repository in place.

The Federal Energy Office (within the Department of Transport, Communication and Energy) is responsible for setting criteria for waste management practices, including geologic disposal. The Federal Council is advised by a Working Group for Waste Management with representatives from various agencies. NUCLEAR FUEL CYCLE $(7)$

The Swiss utilities purchase their fuel from foreign suppliers and have contracted with COGEMA (France) and BNFL (UK) for reprocessing services. Under contracts signed before 1980, BNFL and COGEMA will keep the reprocessing wastes. Under later contracts, the reprocessors have the right to return reprocessing wastes to Switzerland if they choose. 
Waste Management $(7,55,56)$

The utilities and the government both take LLW to EIR in Wurenlingen, where the waste is incinerated and stored temporarily. Switzerland often joins with Belgium and the Netherlands in annual sea dumps of their low-level wastes.

The Institute for Reactor Research is investigating techniques for volume reduction of combustible TRU wastes (incineration and acid digestion) and for improving the properties of cement-matrix waste forms.

The Swiss nuclear utilities are now faced with the requirement that by 1985 they be able to guarantee safe and final elimination of their wastes or lose the operating permits for their nuclear stations. To this end, they have instituted a major waste disposal R\&D program directed toward the use of intermediate-depth caverns for low- and intermediate-level wastes and the construction of a deep-hole repository for either vitrified HLW or spent fue 1 elements. The program includes:

1. Development of granite repository technology including:

- characterization of up to 12 sites, including borehole driling and hydrogeological and geophysical studies

- installation of a granite field laboratory in the Grimsel Pass area of the Alps for hydrogeological studies of rock fracture and water flow, geophysical studies, and plugging and sealing tests

- design studies for deep-hole $(2500 \mathrm{~m})$ storage and for mined repositories

- safety analysis.

2. Evaluation of shallow-land burial of short-lived LLW and rock caverns 100-600 $\mathrm{m}$ below the surface for actinide-free LLW and MLW with intermediate half-life radionuclides. Clay, anhydrites, and limestones are being considered as potential host rock formations (NAGRA).

3. Radionuclide transport studies (EIR) including:

- $K_{D}$ measurements

- transport modeling. 
4. Development of quality control techniques for HLW canisters to be received from foreign reprocessors of Swiss spent fuels.

5. Participation in international (NEA) joint R\&D project at Stripa, Sweden.

6. Development of spent fuel canisters and techniques for dry storage of spent fuels.

Major Milestones

- Acid digestion plant for plutonium wastes 1982

- Field laboratory in a granite formation 1982

- Feasibility of safe and final disposal 1984 demonstrated

- Initial receipt of HLW glass from COGEMA 1992 (France)

- Surface storage facility or ultimate repository 1995 for LLW/MLW

- Geologic repository for HLW or spent fuels 2020

\section{TAIWAN REPUBLIC OF CHINA}

The Taiwan Republic of China has indigenous coal and off-shore gas, but no appreciable oil; it imports nearly $80 \%$ of its fuel. The island's hydropower potential has been nearly completely developed. Hence, the country is looking to nuclear power to meet the rapidly growing demand for electric energy. In 1977, the total installed electric power capacity was 7.0 GWe, of which 1.4 GWe was hydro, 5.0 GWe was thermal, and 0.6 GWe was nuclear. (57) Taiwan has three BWRs (2.2 GWe) installed, and one BWR (950 MWe) and two PWRs (1.8 GWe) under construction.

\section{ORGANIZATION}

Nuc lear power plants in Taiwan are government-owned and operated by Taiwan Power (Taipower), which generally depends on foreign vendor organizations for technical help. The Atomic Energy Council has functions similar to those of US NRC, but also is responsible for waste disposal. Research in the nuclear field is handled by the Institute of Nuclear Energy Research. 
NUCLEAR FUEL CYCLE

The government wishes to develop LWR fuel fabrication capability and is seeking foreign technology. Taipower's strategy is to develop first a fuel assembly plant (by 1986), then a fuel hardware plant, a U0, pellet plant, and finally UF 6 conversion capability. A decision on domestic reprocessing is to be made by $1985-1986$.

Reactor wastes are to be transported in 50-gallon drums to the new National waste Storage facility on Orchid Island, off Taiwan's southeastern coast.

\section{UNION OF SOVIET SOCIALIST REPUBLICS}

The Soviet Union has large fossil fuel resources, but these are being depleted in the European part of the country where the major population centers are found, and costs to transport fuel from east of the Ural Mountains are high. Hence the government has embarked on a strenuous program to develop a strong nuclear power industry.

As of January 1982, Russia had 35 power reactors (14 GWe) operating, 23 (22 GWe) under construction, and 17 (18 GWe) in the planning phase. These included PWRs, reactors of a light water-cooled, graphite moderated, pressure tube design, and LMFBRs. Government plans call for 1) 90-100 GWe nuclear power capacity by 1990, representing about $20 \%$ of the total electric power capacity of the country, and 2) continued construction of fast breeders. $(58,59)$ The Soviet Union also cooperates with its CMEA partners in an integrated CMEA nuc lear power program. Current and planned nuclear capacities of the CMEA countries outside Russia are: 


\begin{tabular}{|c|c|c|c|}
\hline & \multicolumn{3}{|c|}{ MWe (No. of Reactors) (58) } \\
\hline & Operable & $\begin{array}{c}\text { Under } \\
\text { Construction } \\
\end{array}$ & Planned \\
\hline Bulgaria & $1224(3)$ & $1420(2)$ & $4000(4)$ \\
\hline Cuba & & $840(2)$ & \\
\hline Czechos lovakia & $952(3)$ & $2520(6)$ & $9316(13)$ \\
\hline $\begin{array}{l}\text { German Democratic } \\
\text { Republic }\end{array}$ & $1712(5)$ & $3264(8)$ & $1632(4)$ \\
\hline Hungary & & $1632(4)$ & $4000(4)$ \\
\hline Poland & & 440 (1) & $5440(6)$ \\
\hline Rumania & & $1200(2)$ & $1640(3)$ \\
\hline Yugoslavia & $632(1)$ & & $1000(1)$ \\
\hline
\end{tabular}

Fuel cycle industrial-scale activities are presently limited to mining and enrichment of uranium, fabrication of fuels for LWRs and LMFBRs, and spent fuel storage. In the future, the domestic fuel cycle will be expanded to include spent fuel reprocessing and HLW vitrification. Eventually, a geologic repository for HLW glass is to be built.

\section{ORGANIZATION}

The overall responsibility for nuclear development in the Soviet Union rests with the USSR State Committee on Utilization of Atomic Energy and the Ministry of Energy and Electrification.

Other agencies and research centers of importance to Soviet radioactive waste management R\&D programs include:

- Institute of Physical Chemistry, Moscow, a branch of the USSR ACademy of Sciences (geologic waste disposal; waste form properties)

- V. G. Khlopin Radium Institute, Leningrad (chemical separation; fuels reprocessing; geochemistry) 
- All-Union Scientific Research Institute for Inorganic Materials, Moscow (properties of solid waste forms)

- Chemical Plant Research Institute, Sverdlovsk (vitrification pilot plants).

\section{NUCLEAR FUEL CYCLE}

\section{Fuels Production}

The Soviet Union has large indigenous uranium resources and is also supplied with uranium ore and concentrate by East Germany, Czechoslovakia, Hungary, and Bulgaria. The nation has enrichment facilities, developed to support the weapons program, and fuel fabrication capability.

\section{Spent Fuel Management}

Russia supplies fuel for the reactors it sells and takes back the spent fuel. Fuel cycle plans are based, at least in part, on reprocessing of spent fuel, but a reprocessing $\mathrm{plant}$ for power reactor fuels has not been built as yet. Hence spent fuel assemblies from foreign and domestic reactors are being stored at power plant sites and at least one AFR.

The government sponsors R\&D on the reprocessing of LWR and FBR fuels and has at least one small pilot plant. Aqueous processes and a gaseous fluorination technique are being studied. $(59,60)$

Waste Management ${ }^{\text {(61-63) }}$

Russian strategy for managing radioactive wastes calls for:

1. Treatment and immobilization (in bitumen or cement) of low- and intermediate-level wastes, followed by disposal in regional storage centers.

2. High-level waste from reprocessing will be converted to a phosphate glass, stored in surface facilities for a period, then placed in a suitable geologic repository--probably salt. 
Research and development activities include studies of:

1. HLW vitrification - Two non radioactive waste vitrification pilot plants have been built for HLW vitrification studies--the KS-KT-100 plant, which uses a two-stage process (fluid bed calcination followed by melting in a concrete-refractory storage pot); and a single-stage continuous process using a two-zone melter. Other high-level waste forms are also being evaluated, including vitromets (glass beads in metal matrices, and ceramics).

2. Low- and intermediate-level waste treatment

- incineration and acid digestion for volume reduction

- immobilization by cementation or by encasement in thermoplastic materials

- disposal of bituminized wastes in shallow trenches in clay formations.

3. Treatment of TRU wastes and spent fuel cladding hulls.

4. Processes for handling off-gases and storing $85_{\mathrm{Kr}}$.

5. Geologic disposal

- injection of liquid non-HLW into deep, porous strata

- criteria development, repository design and engineering, testing of prototypes, and studies of bulk rock behavior for repositories in salt, granite, and sandstone formations.

\section{THE UNITED KINGDOM}

Nearly $90 \%$ of the United Kingdom's primary energy requirements are met with indigenous resources. In 1979, British plants produced 283.4 TWh electrical energy from solid fuels ( 47.7 Mtoe), oil (10.4 Mtoe), nuclear (9.3 Mtoe), hydro (1.1 Mtoe), and gas (0.6 Mtoe). (5)

The United Kingdom consumed energy equivalent to 221 million tonnes of oil (Mtoe) in 1979, 12\% of the fuel being imported. Principal domestic supply sources were coal, oil, gas, and nuclear. Electric generating capacity in 1980 was 82 GWe. (5) 
The first nation to install commercial nuclear power plants, the United kingdom has a long-standing commitment to this source of power. The country's commercial power reactors are all of their own gas-cooled design, but the government has carried on an advanced LMFBR test program for many years and now plans to build at least one commercial PWR.

Great Britain has built two generations of gas-cooled reactors: the GCR, fueled with Magnox-clad uranium metal, and the AGR, fueled with SS-Clad $\mathrm{UO}_{2}$. At the end of 1981, there were 26 GCRs ( 5.2 GWe), seven AGRs ( 4.3 GWe), and one demonstration LMFBR (0.25 GWe) operational; seven AGRs ( 4.5 GWe) are under construction.

Fuel cycle and waste management strategy includes reprocessing; stockpiling of plutonium; eventual FBR use; vitrification of HLW; interim storage of the HLW glass for 50 years or longer to allow radioactivity and thermal power to decay; and eventual terminal disposal of all radioactive wastes. (7)

\section{ORGANIZATION}

Major fuel cycle and waste management responsibilities in the United Kingdom are assigned as follows: $(7,64)$

1. The United Kingdom Atomic Energy Authority (UKAEA) sponsors and administers reactor, fuel cycle, and waste management R\&D. The Authority operates through the Headquarters Group in London, the Northern Division (headquarters at Risley), the Research Group (headquarters at Harwe11), and the Safety and Reliability Directorate at Culcheth, Cheshire, which advises on the formulation and application of safety and reliability policy.

The Research Group has two research sites:

- The Atomic Energy Research Establishment (AERE), Harwe11, which directs about one-half of its effort directly to problems of reactor development and nuclear power, including fuel reprocessing, waste treatment, and waste disposal.

- The Culham Laboratory, Abingdon, is concerned with nuclear fusion and plasma physics. 
The Northern Division is responsible for the design and development of nuclear reactors, including the UK's LMFBR, and the LMFBR fuel cycle. The UKAEA has R\&D facilities at the following Northern Division sites:

- Risley Nuclear Power Division Establishment incorporates the Northern Division Headquarters, the Engineering Division, the Risley Engineering and Materials Laboratory, and supporting groups.

- Dounreay Nuclear Power Development Establishment (DNPDE) is the major site for fast breeder reactor and fast reactor fuel cycle development.

- Reactor Fuel Element Laboratories, Springfields, is responsible for development and environmental testing of fuels, engineering for thermal and fast reactors, and development of advanced waste treatment processes.

- Reactor Development Laboratory, Windscale, develops AGR fuels and plutonium fuels for fast breeder reactors.

- Atomic Energy Establishment, Winfrith, is responsible for thermal and fast reactor research.

2. British Nuclear Fuels Limited (BNFL) is an essentially autonomous organization which provides commercial fuel supply services. Owned by the government with a 11 the shares held by the UKAEA the company is divided into three divisions covering uranium enrichment (Capenhurst), fuel manufacture (Springfields), and spent fuel reprocessing (the windscale facilities at Sellafield).

3. The Department of Environment (DOE) has responsibility to direct and coordinate UK waste management technical activities, including the geologic disposal program. Waste management R\&D is performed by other departments and by several DOE agencies, the Institute of Geological Sciences (Harwell), the Institute of Oceanographic Sciences (Wormley, Godalming), and the Building Research Establishment (Garston, Watford). 
4. The Health and Safety Executive (Health and Safety Commission) is responsible for occupational health and safety in all nuclear establishments. One of its agencies, the Nuclear Installations Inspectorate (Liverpoo1), licenses construction and operation of nuclear installations.

5. The National Radiological Protective Board (NRPB), Harwe11, is responsible for all radiological protection $R \& D$ services.

6. The Ministry of Agriculture, Fisheries and Food (MAFF) oversees the Fisheries Radiobiological Laboratory (FRL) at Lowestoft which conducts radiological research in the aquatic environment. MAFF, the Department of Environment, and the Scottish Development Department have joint responsibility for authorizing routine discharges of radioactivity to the environment.

NUCLEAR FUEL CYCLE

Fuels Production $(7,64)$

Great Britain is not at present a uranium producer, although limited mining has occurred in the past and a number of private and foreign companies have a continuing interest in evaluating the uranium production potential. BNFL fuels production activities include:

1. Uranium enrichment through a 500-tSWU/yr gaseous diffusion plant and the Urenco gas centrifuge plant, both at Capenhurst

2. Uranium conversion and fabrication of fuels for Great Britain's power reactors

3. MoX fuel fabrication in plants at the Sellafield Works. Spent Fuel Management $(7,8,65)$

Through its nuclear weapons program, the UK has been reprocessing spent fuels since 1952. Defense and commercial Magnox fuels are currently treated in BNFL's Windscale reprocessing plant (5tHM/day) at the Sellafield Works. A 2 t/day chop-leach head-end for LWR oxide fuels was added to the Windscale 
plant in 1969 and operated intermittently until 1973, when an accidental release of radioactive elements occurred and the plant was shut down. Construction has started on a new BNFL reprocessing plant, THORP, located at Sellafield, which will handle domestic and foreign uranium oxide fuels from AGRs and LWRs. Design capacity is $6 \mathrm{t} / \mathrm{day}$, with startup scheduled for about 1990.

Reprocessing of spent FBR fuels has been carried to the advanced demonstration phase with operation of the PFR Reprocessing Plant at Dounreay. Built as a pilot plant, the facility was operated for several years, then decontaminated and rebuilt. With a nominal capacity of 9-10 tHM/yr, it now hand les spent fuel from the Dounreay 250-MW Prototype Fast Reactor Construction of a larger FBR reprocessing plant is under consideration.

Improved reprocessing techniques and processes are being developed by the UKAEA at Harwell and Dounreay (FBR MOX fuels) and by BNFL at Windscale (AGR and $L W R \mathrm{UO}_{2}$ fuels).

Waste Treatment $(7,10,65)$

The UKAEA and BNFL have had a rising-level, in-pot vitrification process (FINGAL-HARVEST) in development for several years at Harwell and Risley, with nonradioactive pilot-scale studies and preparations for a radioactive pilot plant, a cold full-scale prototype, and a commercial demonstration plant. This effort has been supported by a variety of product characterization studies and other laboratory work. BNFL has now chosen the AVM process for the Windscale vitrification plant, but work continues on second-generation processes such as the ceramic melter (Harwe11) and a technique depending on the use of microwave heating for calcination and melting (Springfields).

Considerable effort is devoted to the treatment and immobilization of nonhigh-level wastes: volume reduction, fixation and characterization of TRU wastes and fuel cladding hulls (AERE-Harwell and BNFL-Windscale); treatment of reactor wastes (Central Electricity Generating Board, CEGB); incineration (BNFL-Windscale); control and storage of volatile radionuclides (Harwel1); spent solvent cleanup and disposal (Harwel1); and fixation of nuclides in various matrices (Harwel1). 
Waste Disposal $(7,66)$

Low-level liquid and gaseous effluents from nuclear plants are diluted and dispersed in the environment after treatment to assure compliance with discharge regulations. Low-activity solid wastes (lightly-contaminated protective clothing, tools, and other trash) are placed in shallow trenches near the Sellafield site. Other solid wastes of slightly higher activity levels are packaged and dropped into the ocean under OECD/NEA surveillance, at a dump site in the North East Atlantic. All other wastes, of higher activity, are held in storage pending the installation of treatment plants and terminal disposal facilities. The government may decide to provide geologic isolation for intermediate-level wastes, perhaps in an existing mine.

Improved techniques for packaging of solid low-level wastes for sea dumping are under investigation at Harwell and Windscale, and various options are being evaluated for disposal of high-level and alpha-bearing wastes. Options being considered include disposal in a deep geologic formation (crystalline rock, argillaceous, or evaporite), on the seabed, and below the seabed. R\&D work for this project includes high pressure/high temperature geochemical studies, measurements of the migration of radionuclides, evaluation of granite formation properties, and oceanographic investigations. Applications for approval of exploratory drilling at a number of sites, in granite, clay, and interbedded clay/salt formations, were submitted by the Institute of Geologic Sciences, but local opposition has so far prevented any drilling activity except in northern Scotland, near the Dounreay site. In late 1981, the government decided to plan for long-term (50 years or longer) engineered storage of HLW glass prior to $\mathrm{placement}$ in a repository. This decision removed the urgency to seek and develop an actual repository site for disposal of heat generating waste, and applications for exploratory drilling programs for site characterization were cancelled.

\section{INTERNATIONAL RELATIONS}

Worldwide attempts to limit the spread of nuclear weapons and the desire to show good faith with these attempts strongly color the international relations in the nuclear fuel cycle area among nations. Therefore, in this sec- 
tion we will discuss these global nonproliferation activities and their relevance to cooperation in the fuel cycle, list particular multilateral relationships and projects in which the US is involved, as well as describe international agencies specifically involved in the nuclear fuel cycle.

NONPROL IFERATION ACTIVITIES

International Atomic Energy Agency Safeguards

The International Atomic Energy Agency (IAEA) was established in 1956 primarily to set up and maintain safeguards to detect the diversion of nuclear materials and equipment for military use and to provide assistance in development and application of atomic energy for peaceful uses. It was decided that safeguards were (and still are) required on all IAEA technical assistance projects, and they would be available for other particular projects when the countries involved with the project requested them. The safeguards include IAEA's right and responsibility to:

- examine and approve nuclear facility design

- require maintenance of operating records to ensure accountability of nuc lear materials

- send inspectors on-site to assure that nuclear materials, equipment, or facilities are not being used for military purposes.

As well as being available to safeguard particular projects, the IAEA in some cases also became a third party in previously bilateral nuclear technology exchange agreements between countries.

Treaty on Non-Proliferation of Nuc lear Weapons

The Treaty on Non-Proliferation of Nuc lear Weapons (NPT), negotiated over a period of years under the co-chaimanship of the US and the USSR, became effective March 5, 1970. As of November 1981, (70) three nuclear weapon states (US, USSR, and UK) and 111 (see Table 6) non-nuclear weapon st ates have ratified the NPT. Conspicuous among those who have not acceded are France and China (nuclear weapon states), India and Israel (almost nuclear weapon states), and Argentina, Brazil, Chile, Columbia, Egypt, Pakistan, South Africa, and 
Spain (countries with some nuclear fuel cycle capabilities or potential). It is hoped that Spain may still ratify the NPT, and the Latin American countries listed are party to the Treaty of Tlatelolco which will be discussed later.

The basic tenets of the NPT include:

- Nuclear weapon states will not transfer nuclear we apons to nonnuclear weapon states.

- Non-nuc lear weapon states will not acquire nuclear weapons.

- Non-nuclear weapon states must accept IAEA safeguards on all the ir nuclear activities.

- All ratifiers have the right and should cooperate with others to use nuclear energy for peaceful purposes.

- All parties must pursue negotiations which might lead to a cessation of the nuclear arms race or total nuclear disarmament.

Of the 111 non-nuclear weapon states which have rat if ied NPT, safeguards agreements (which are to be negotiated within 18 months of ratification by terms of the treaty) have been negotiated or are in force with 80 (see Table 6). (70) Treaty of Tlatelolco

Latin America is the only area of the world which enjoys a nuclear-weaponfree status. To maintain this position, the Treaty for the Prohibition of Nuclear Weapons in Lat in America, commonly known as the Treaty of Tlatelolco, was negotiated. Since the treaty was opened for signature on February 14, 1967, all Latin American republics have signed it except one--Cuba. Only Argentina has not ratified it. The treaty is in effect for 20 of the 22 rat ifiers; Brazil and Chile have not waived one requirement of the treaty which says it will not be in force until all signers have ratified it. Parties to this treaty agreed:

- not to aquire nuclear weapons or allow them to be stationed in their territories

- to accept IAEA safeguards for civil nuclear energy facilities. 


\section{TABLE 6. Non-Nuclear-Weapon States Party to NPT(a)}

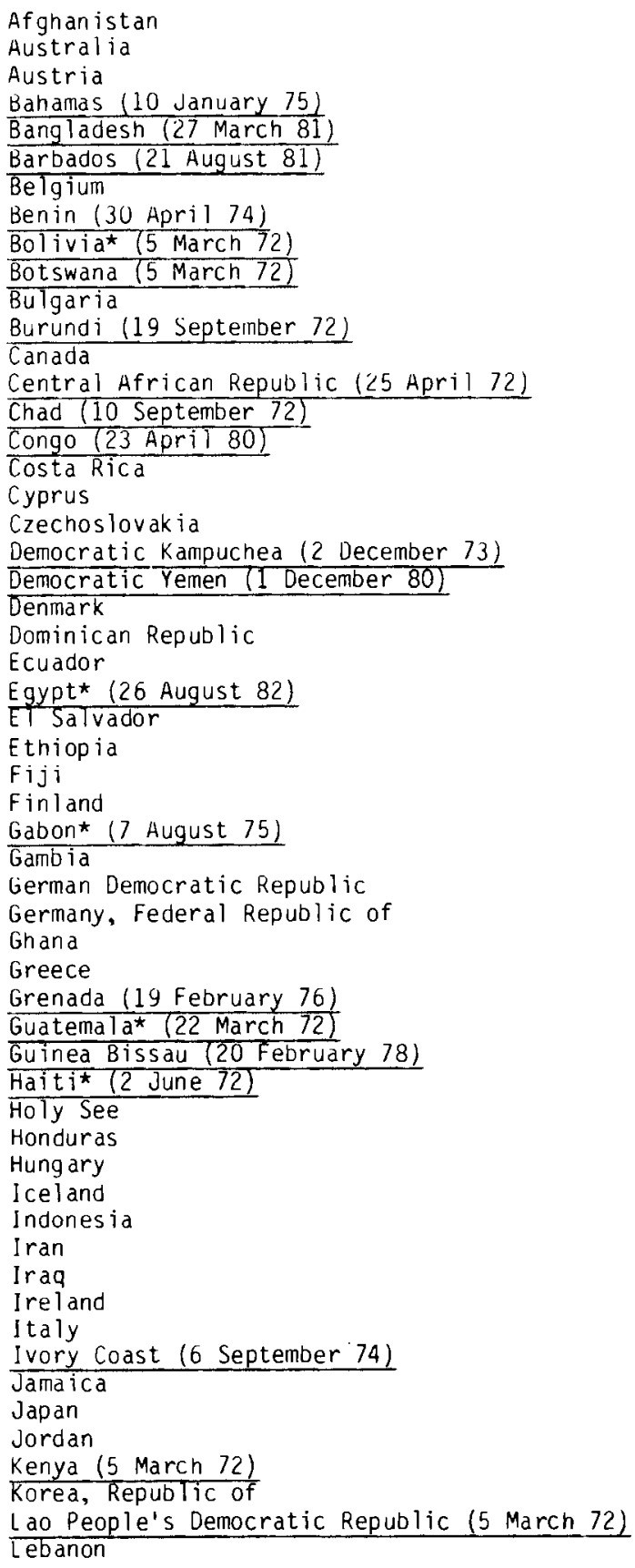

Notes: Underlined states do not have NPT safeguards agreements in force.

* - Safeguards agreement approved by the IAEA Board of Governors and awaiting entry into force.

(a) International Atomic Energy Agency Bulletin, Vol. 23, No. 4, December 1981, p. 30.

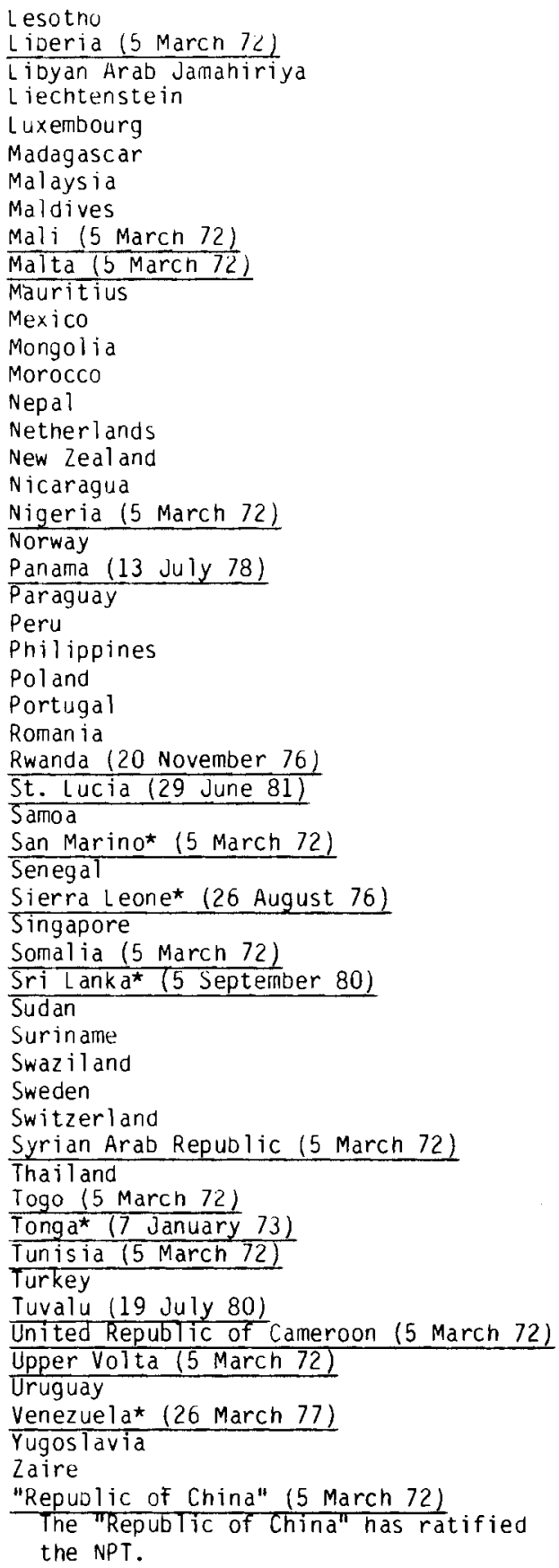


The treaty also binds outside powers responsible for territories within the treaty area and nuclear weapon states to respect the nuclear-weapon-free status of the treaty area.

\section{London Nuc lear Suppliers' Group}

In January 1978, representatives from major nuclear supplier countries met in London to coordinate their national policies concerning transfer of sensitive nuclear technologies. The group which later expanded to represent 15 countries--Belgium, Canada, Czechoslovakia, East Gemany, France, Italy, Japan, Nether lands, Poland, Sweden, Switzerland, Soviet Union, United Kingdom, United States, and West Gemany--adopted a set of guidelines.

The guidelines are based on a "trigger list" of nuclear materials and technologies which can be transferred only when placed under IAEA safeguards. The list itself was developed in 1974 by an earlier suppliers' meeting. The trigger list includes:

- source and special nuclear materials

- reactors and reactor equipment

- deuterium, heavy water, and plants for their production

- nuclear grade graphite

- reprocessing, enrichment, and fuel fabrication plants.

Those transferring these items under the guidelines, should place them under IAEA safeguards, physically protect them, and pledge not to use them in any way which would result in a nuclear explosive device. Recip ients should agree not to use transferred equipment or technology to enrich uranium more than $20 \%$ $\mathrm{U}^{235}$ nor to transfer any trigger list items to a third party except under the same conditions as the original transfer.

The suppliers also encouraged multinational rather than national efforts to establish facilities for enrichmerit and reprocessing.

The suppliers' guidelines, however, are in no way binding to the countries represented, though they go a long distance toward coordinating national policies to support and supplement NPT. 
The desire for nonproliferation of nuclear weapons of the nations who have participated in these activities is reflected in varying degrees in their individual national policies concerning exchange of nuclear fuel cycle information. and technology. For example, Canada and the US will not export uranium or reactors to nonweapon states who have not ratified NPT or in some way accepted full scope IAEA safeguards. Australia will not sell uranium to nonweapon states who have not ratified NPT. Even when national policy is not as blat ant as these examples, a nation's nonproliferation status definitely has a bearing on individual decisions to cooperate on fuel cycle matters.

\section{UNITED STATES' MULTILATERAL AGREEMENTS AND PROJECTS}

At present, the US has bilateral agreements to exchange fuel cycle technology or information in place with Belgium, Canada, Federal Republic of Germany, Japan, Sweden, and United Kingdom. Extension to a previous bilateral agreement with the Commission of the European Communities (CEC) is currently being negotiated, and negotiations are in progress to establish a similar agreement with France.

In addition to general agreements to exchange nuclear fuel cycle technology and information, the US has specific agreements with West Germany to conduct experiments at the Asse salt mine and with Japan to conduct nuclear fuel transportation systems accident analyses. The US is party to a multilateral agreement under OECD/NEA sponsorship with Finland, Japan, Sweden, and Switzerland to carry out geologic tests in the Stripa mine in Sweden. (This project is discussed further in the Sweden section.)

Another multilateral agreement under OECD/NEA sponsorship is in place with Canada, Finland, France, West Germany, It aly, Japan, Netherlands, Sweden, Switzerland, United Kingdom, and the US to participate in the International Sorption Information Retrieval System, a data bank concerning sorption of radionuclides on various rock types and solubility of key radionuclide compounds. Presently nine of the eleven countries have completed laboratory radionuclide sorption standard coding forms and all of this data has been installed in a US system administered by Pacific Northwest Laboratories in Richland, WA. If this preliminary work gives favorable results, the system may be transferred to a computer center in Europe. 
INTERNATIONAL AGENCIES

Several international organizations, with somewhat overlapping memberships, devote major attention to nuclear fuel cycle and radioactive waste management problems. Common objectives are to foster cooperation and information exchange among their members, identify and minimize duplication of R\&D effort, and develop information for the assessment of radioactive waste management practices.

International Atomic Energy Agency

The International Atomic Energy Agency (IAEA) is an independent organization which belongs to the United Nations family. The IAEA embraces developing and developed countries as well as nations having either privately or centrally controlled economic systems; its membership comprises 110 nations. It is governed by the General Conference, consisting of a representative from each Member State, and by the 34-member Board of Governors, the Agency's executive body. Detailed work of the Agency is handled by the Secretariat. Extensive use is made of technical committees and consultants. The committees are generally established on an ad hoc basis, with a specific short-term assignment, although there are also technical committees which work on a continuing basis.

The IAEA has a number of specific objectives for its radioactive waste management programs:

- to disseminate up-to-date information concerning safe methods for managing radioactive wastes and maintaining acceptable radioactivity levels in effluents from systems which handle radioactive materials

- to coordinate and/or promote the development of technology for safe management of radioactive wastes

- to issue safety guidance on all aspects of radioactive waste management

- to assess the consequences of releases of radionuclides into the environment from nuclear activities

- to provide technical advice, training, and assistance to Member States, upon request 
- to conduct or participate in studies considering regional or worldwide planning of the nuclear fuel cycle.

These objectives are met primarily by organizing and conducting various kinds of meetings, usually among experts from Member States, and by preparing and publishing reports. The meetings include Conferences and Symposia, often cosponsored with another organization such as the NEA or CEC; Advisory Groups (with representatives assigned by their governments) convened to review and advise on program content, methods of conducting programs, etc.; Technical Committees which review Agency programs or reports in depth; consultants brought in from Member States to perform a specific technical task such as preparing or modifying a technical report; Coordinated Research Programme meetings to coordinate the research in a specific technical area among various institutes; and Review Groups, assembled occasionally to review program progress and direction.

\section{Nuc lear Energy Agency}

The Nuclear Energy Agency (NEA) is a semiautonomous subsidiary of the Organization for Economic Cooperation and Development (OECD). Membership, primarily European with a sprinkling of other nations with privatelycontrolled economies, includes:

$\begin{array}{llll}\text { Australia } & \text { France } & \text { Japan } & \text { Sweden } \\ \text { Austria } & \text { Germany (FRG) } & \text { Luxembourg } & \text { Switzerland } \\ \text { Belgium } & \text { Greece } & \text { Netherlands } & \text { Turkey } \\ \text { Canada } & \text { Iceland } & \text { Norway } & \text { United Kingdom } \\ \text { Denmark } & \text { Ireland } & \text { Portugal } & \text { United States. } \\ \text { Finland } & \text { Italy } & \text { Spain } & \end{array}$

(New Zealand and Yugoslavia cooperate in certain projects.)

The work of NEA is carried out under the authority of the OECD Counc $i l$ and under the general guidance of the Steering Committee for Nuclear Energy made up of representatives of all Member countries, the Commission of the European Communities and the International Atomic Energy Agency. The Steering Committee... is in turn assisted by other committees and working groups of specialists 
appointed by the Member countries from the relevant ministries, administration or governmental institutions. These committees, acting generally as think tanks or as organisers of practical forms of intergovernmental co-operation, keep the scientific and technological developments in their fields under continuing review and direct the work of NEA towards those problem areas in which the Agency can make a useful and disinterested contribution. (71)

There is also a small Secretariat, its function being to assist the Steering Committee and its subsidiary committees and working groups.

Early in its existence, the European Nuclear Energy Agency (forerunner of the NEA) fostered the establishment of several joint projects by groups of interested Member States. Notable examples of this are the Eurochemic fuel reprocessing demonstration plant at Mol, Belgium, built and operated by 13 countries; the Halden Reactor Project; and the Dragon High-Temperature Reactor Project.

Until 1975 in the waste management field, ENEA and then NEA were primarily involved in collecting and disseminating information for the Member States, occasionally sponsoring or cosponsoring international symposia and seminars, and preparing specific documents on radioactive waste management practices. In 1975 the NEA established its Radioactive Waste Management Committee (RWMC) with the assigned purpose of initiating, encouraging, and coordinating cooperative R\&D activities among the Member States. In 1980, following a several-year period of holding workshops, sponsoring symposia and seminars, and initiating NEA coordination of multilateral projects, the RWMC devoted a special meeting to consideration of its role in waste management and defined the following objectives:

1. to back up national radioactive waste management and demonstration programs through a) generic studies of related technical issues, b) issuing international concensus statements, recommendations, and guides on criteria, methods, and procedures, and c) continually improving the data base available to Members 
2. to improve the effectiveness of national R\&D programs through a) developing mechanisms to improve the coordination of national R\&D programs in selected areas, b) promoting and coordinating joint international R\&D projects with limited scope and membership, and c) undertaking and reporting international evaluations of the results of such programs and projects

3. to assist Members in improving public understanding of radioactive waste management issues and options, particularly in the field of waste disposal.

One of NEA's current international projects is the Seabed Working Group. Annual meetings have been held since 1976 to discuss the feasibility of disposing of high-level waste in subseabed formations. Cooperative research vessel cruises and experiments to this end are also coordinated through the working group. Emphasis has recently split into two special task groups which will study benthic boundary layer considerations and social-legal-political aspects.

The US also participates in a NEA-sponsored Executive Group for Research and Surveillance on Sea Disposal of Low-Level Radioactive Waste. The purpose of this group is to provide for cooperation among the Member States concerning standards, guidelines, and recommendations for dumping treated low-level radioactive waste at sea. The efforts of this have been subdivided into five research task groups: physical oceanography, geochemistry, biology, model development, and radiological surveillance.

Other NEA committees involved with fuel cycle matters include Committee on Radiation Protection and Public Health (CRPPH) and Committee on Safety of Nuclear Installations (CSNI).

The NEA also interacts with two other OECD bodies in waste management matters: the International Energy Agency, which is concerned with nuclear energy as one of a number of alternative energy sources; and the OECD Environment Committee. 
Commission of the European Communities

The Commission of the European Communities (CEC) is the agency which administers the cooperative economic and energy-related activities initiated under the European Coal and Steel Community, the European Economic Community, and Euratom. The Member States, which are also NEA members, include:

$\begin{array}{ll}\text { Belgium } & \text { Ireland } \\ \text { Dennark } & \text { Italy } \\ \text { France } & \text { Luxembourg } \\ \text { Germany (FRG) } & \text { Netherlands } \\ \text { Greece } & \text { United Kingdom. }\end{array}$

The European Coal and Steel Community (ECSC) was created in 1951 to pool the coal and steel production of the six member states. In 1957 the European Economic Community (EEC) and the European Atomic Energy Community (Euratom) were formed by the same six Member States. In 1967 the ECSC, EEC, and Euratom commissions were merged into the Commission of the European Communities (CEC), which assumed the responsibility to formulate and implement policy for the three communities.

Euratom objectives were to: develop nuclear research capability; establish nuclear safety standards; encourage the development of nuclear power; and exchange information and capital for nuclear enterprises among the member states. Euratom resources include the Joint Research Centre (JRC) with research establishments at: Ispra, Italy (JRC-Ispra); Mol, Belgium (Central Bureau for Nuclear Measurements); Petten, Netherlands (Petten CCR); and Karlsruhe, FRG (European Institute for Transuranium Elements, EIT).

The provisions of the original treaty establishing Euratom are still in effect, and Euratom objectives for the cooperative development of nuclear energy are a major CEC program.

Supported by funds received through taxing the Member States, the CEC contributes heavily to two types of waste management R\&D programs: the "direct action" programs carried out at Euratom $\mathbb{R C}$ sites, primarily the Ispra and Karlsruhe laboratories; and the "indirect action" programs conducted by the 
Member States under a joint-funding arrangement in which the CEC pays up to one-half of the costs of designated projects. Direct action programs are generally planned, budgeted, and approved on a 4-year cycle, indirect action programs on a 5-year cycle.

Results of the CEC-sponsored R\&D programs are disseminated freely among the Member States, but CEC approval is required for transmitting such information outside the community.

\section{Council for Mutual Economic Assistance}

The Council for Mutual Economic Assistance (CMEA) is the counterpart of the OECD for countries with centrally-controlled economies. The mission of the CMEA is to promote economic and industrial cooperation among the Member States (Bulgaria, Cuba, Czechoslovakia, German Democratic Republic, Hungary, Mongolia, Poland, Rumania, USSR, and Yugoslavia). The CMEA has a Standing Commission on the Use of Atomic Energy for Peaceful Purposes, which holds meetings to review national waste management programs and define areas for additional cooperation.

Nord ic Counc il

The Nordic Council is organized for discussion and action in areas of common interest among its members. Member States cooperate in various waste treatment R\&D programs. Council membership includes Denmark, Finland, Iceland, Norway, and Sweden; headquarters are in Stockholm.

International Commission on Radiological Protection

The International Commission on Radiological Protection (ICRP) provides principles of radiation protection as a basis for each country to use to establish technical codes of practice. 


\section{REFERENCES}

1. Nuclear power capacities for non-CMEA countries were taken from "NUKEM Market Report," May 1982. Dat a for CMEA countries came from recent issues of Energy in Countries with Planned Economies.

2. Uranium: Resources, Production and Demand. A joint report by the OECD/NEA and the IAEA, February 1982.

3. D. L. Tweedale. "Argentina." Nuclear Power in Developing Countries, J. E. Katz and 0. S. Marwah, D.C. Health and Company, Lexington, Massachusetts, 1982, pp. 79-96.

4. "Argentina Seeks Salf-Sufficiency." Nuclear Engineering International, May 1982, p. 7.

5. Energy Policies and Programmes of IAEA Countries. OECD/International Energy Agency, Paris, 1980 Review.

6. K. D. Reeve, D. M. Levins, E. J. Ramm, J. L. Woolfrey, W. K. Bukyx, R. K. Ryan, and J. F. Chapman. "The Development and Testing of Synroc for High Level Radioactive Waste Fixation." In proceedings from Waste Management '81, Tucson, Arizona, Vol. 1, pp. 249-266.

7. Assessment of National Systems for Obtaining Local Acceptance of Nuclear Waste Management Siting Activities. IEAL-232, International Energy Assoc iates Limited, Washington, DC, 1981.

8. P. Zuehlke. "Facts and Trends in European Nuclear Fuel Reprocessing." Presented at the International Conference on the Fuel Cycle, Amsterdam, September 14-17, 1980.

9. P. Dejonghe. "Development of Conditioning and Disposal Methods for Radioactive Wastes in Belgium." In proceedings from Waste Management '81, Tucson, Arizona, 1981, Vo1. 2, pp. 985-994.

10. W. Heimer1. "A State of the Art Review of Vitrification of High Level Wastes in Europe." Transcript of a conference on Radioact ive Waste Management in Perspective, September 26, 1980, London, published by Scientif ic and Technical Studies.

11. P. Schmidt. "Possibilities of High Temperature Waste Incineration with the FLK Slagging Process." In proceedings from a NEA Workshop on High Temperature Inc inerat ion, RWM(80)1, Mo 1, Be 1gium, November 6-8, 1979, pp. 159-173.

12. L. H. Baetslé and M. Mittenpergher. "Disposal in Argillaceous Formations." First European Community Conference on Radioactive Waste Management and Disposa1, Luxembourg, May 20-23, 1980. 
13. V. Johnson. "Brazil." Nuclear Power in Developing Countries, J. E. Katz and 0. S. Marwah, D.C. Health and Company, Lexington, Massachusetts, 1982, pp. 87-117.

14. Nuclear Fuel. January 4, 1982; April 26, 1982; and June 7, 1982.

15. J. Boulton, ed. Management of Radioactive Fuel Wastes: The Canadian Disposal Program. Whiteshel1 Nuclear Research Establi shment, AECL-6314, October 1978.

16. T. S. Drolet. "On-Site Management of Reactor Wastes by a Canadian Power Utility." In proceedings of a conference on the On-Site Management of Power Reactor Wastes, OECD-IAEA, Zurich, Switzerland, March 26-30, 1979, pp. 53-66.

17. E. L. J. Rosinger and T. E. Rummery. "Canadian Nuclear Fuel Waste Management Program." In Proceedings of the 1981 National Waste Terminal Storage Program Inf ormation Meeting, D0E/NWTS-15, November 1981.

18. The World Energy Book. D. Crabbe and R. McBride, eds., Nichols Publishing Company, New York, New York, 1980.

19. Europa Yearbook. Europa Publications, London, 1981.

20. "PRC's Nuclear Program: A Status Report." Nuclear News, February 1982, pp. $77-80$.

21. F. Hasted and S. Mehlsen. "Design and Safety Evaluation of a Danish HighLevel Waste Disposal Facility in Selected Salt Domes." In proceedings of the International Symposium on the Underground Disposal of Radioact ive Wastes, IAEA-SM-243/154, Helsinki, Finland, July 2-6, 1979, pp. 539-552.

22. L. J. Andersen. "The National Danish Programme on Geological Disposal." Presented to the OECD/NEA Coordinating Group on Geologic Disposal, October 1981.

23. Information Please Almanac, 1982. Simon and Schuster, New York, New York, 1982, pp. 114-117, 330-331.

24. Heikki Ni ini. "Finnish Progress Report for 1980-81." Presented to the OECD/NEA Coordinating Group on Geologic Disposal, October 1981.

25. Y. Sousselier. "National and Cooperative Program for Waste Management in France." Presented at ANS Topical Meeting on the Treatment and Handling of Radioactive Wastes held in Richland, Washington, April 1982.

26. R. A. Bonniaud, A. F. Jouan, and C. G. Sombret (CEA-Marcoule). "Large Scale Production of Glass for High Level Radioactive Waste." Nuclear and Chemical Waste Management, Vol. 1, No. 1, 1980, pp. 3-16. 
27. L. Farges. "Industrial Low-Level Waste Management in France." In proceedings of a symposium, Waste Management ' 80: The State of Waste Disposal Technology, Mill Tailings, and Risk Analysis Models, R. G. Post, ed., March 10-14, 1980, Tucson, Arizona, Vo1. 1, pp. 275-289.

28. P. Dierkes, K. Janberg, H. Baatz, and G. Weinhold. "Transport Casks Help Solve Spent Fuel Interim Storage Problems." Nuclear Engineering International, October 1980, pp. 53-57.

29. A. Ziegler and H. Röthemeyer. "German Waste Management Policy." Presented at the 1981 National Waste Terminal Storage Program Information Meeting, Columbus, Ohio, November 1981.

30. S. Weisenburger, W. Grunewald, and H. Koschorke. "Vitrification of Simulated High-Level Waste Using Liquid Feeding to a Joule-Heated Ceramic Melter." In Proceedings of the International Symposium on Ceramics in Nuc lear Waste Management, American Ceramic Society and the US Department of Energy, Cincinnati, Ohio, April 30-May 2, 1979, pp. 86-96.

31. V. W. Schneider (ALKEM). "Status of R\&D Work on Alpha-Waste Treatment in Germany." In proceedings of the Workshop on Waste Washing, NEA, Cadarache, France, November 19-21, 1980, pp. 7-11.

32. M. Laser (KFA). "Experience with Incineration of Low Radioactive Waste in Europe." In proceedings of a symposium, Waste Management 180: The State of Waste Disposal Technology, Mill Tailings, and Risk Analysis Mode1s, Tucson, Arizona, March 10-14, 1980, pp. 661-676.

33. H. 0. Witte and R. Köster. "Recent Developments in Low- and.IntermediateLevel Waste Fixation by Cement." In Proceedings of the International Symposium on Ceramics in Nuclear Waste Management, American Ceramic Society and the US Department of Energy, Cincinnati, Ohio, April 30-May 2, 1979, pp. 127-131.

34. K. Kühn, R. P. Rand1, and H. Röthemeyer. "The Federal Republic of Germany's Program for the Disposal of Radioactive Waste." In proceedings of the International Symposium on the Underground Disposal of Radioactive Wastes. IAEA-SM-243/95, Ot aniemi, Finland, July 2-6, 1979, pp. 65-78.

35. Nuclear News. February 1981, pp. 64-66.

36. R. R. Subramanian and C. Raja Mohan. "India." Nuclear Power in Developing Countries, J. E. Katz and 0. S. Marwah, D.C. Health and Company, Lexington, Massachusetts, 1982, pp. 161-179.

37. K. T. Thomas, N. S. Sunder Rajan, K. Balu, and A. A. Khan. "Management of Radioactive Wastes--An Overview of the Indian Programme." In Proceedings of the IAEA International Conference on Nuclear Power and It s Fuel Cycle, IAEA-CN-36, Salzburg, Austria, May 2-13, 1977, Vo1. 4, p. 409. 
38. T. Ishihara, S. Suzuki, and H. Yoshimura. "Radioactive Waste Management in Japan." Atoms in Japan, Japan Atomic Industrial Forum, August 1980, Vol. 24, No. 8, pp. 11-27.

39. K. Uematsu. "Status of High Level and Alpha Bearing Waste Management in PNC." Presented at ANS Topical Meeting on the Treatment and Handling of Radioactive Wastes held in Richland, Washington, April 1982.

40. Hiwhoa Moon. "A Choice of Energy Policy for a Rapidly Industrializing Country: A Case Study of Korea." August 1981.

41. Young-Sun Ha. "Republic of South Korea." Nuclear Power in Developing Countries, J. E. Katz and 0. S. Marwah, D.C. Health and Company, Lexington, Massachusetts, 1982, pp. 221-244.

42. Nuclear News, April 1982, pp. 71-76.

43. J. Eibenschutz. "Mexico." Nuclear Power in Developing Countries, J. E. Katz and 0. S. Marwah, D.C. Health and Company, Lexington, Massachusetts, 1982, pp. 245-256.

44. K. Kuehn and B. Verkerk. "Disposal in Salt Formations." In Radioactive Waste Management and Disposal: Proceedings of the First European Community Conference, Luxembourg, May 20-23, 1980, pp. 385-419.

45. J. Hamstra and H. M. van Montfrans. "Report on Management and Geological Disposal of Radioactive Waste in the Netherlands." Prepared for the yearly meeting of the OECD/NEA Coordinating Group on Geologic Disposal, Paris, October 7-8, 1981.

46. Shirin Tahir-Kheli. "Pakistan." Nuclear Power in Developing Countries, J. E. Katz and 0. S. Marwah, D.C. Health and Company, Lexington, Massachusetts, 1982, pp. 257-272.

47. Nucleonics Week, April 29, 1982.

48. Nucleonics Week, April 15, 1982.

49. "KBS Annual Report 1981." SKBF Technical Report 81-17, KBS, Stockholm, Sweden.

50. Erik Svenke. "Conditions for Increased Independence in the Nuclear Fuel Cycle." Presented at a Nuclear Energy Symposium held in Mexico City, June 15-17, 1981.

51. "NUKEM Market Report on the Nuclear Fuel Cycle: Special Report-Sweden." January 1979.

52. "Handling and Final Storage of Unreprocessed Spent Nuclear Fuel." KBS, Stockholm, Sweden, 1978. 
53. "Safe Handling and Storage of High Level Radioactive Waste." KBS, St ockholm, Sweden, 1979.

54. Nucleonics Week. October 15, 1981, p. 10.

55. H. Flury and M. Thury. "Progress Report on Geologic Disposa1, 1981." Prepared for the yearly meeting of the OECD/NEA Coordinating Group on Geologic Disposal, Paris, October 7-8, 1981.

56. "Nagra Seeks Okay for Waste Lab in Granite." Nuclear Fuel. March 1, 1982 , p. 11.

57. Yung Wei and Yu Hao Lee. "The Republic of China." Nuclear Power in Developing Countries, J. E. Katz and 0. S. Marwah, D.C. Health and Company, Lexington, Massachusetts, 1982, pp. 301-311.

58. Worldwide Nuclear Power. U.S. Department of Energy, January 1982.

59. "USSR-Forging Ahead with Two Reactor Types." Nuc lear Engineering Internationa 1. October 1981.

60. "Top Official Provides Glimpse into Soviet Nuclear Program." Nucleonics Week. September 4, 1980.

61. "USSR, German Fast Reactors." Nuclear News. June 1982, p. 90.

62. Energy in Countries with Centrally Planned Economics, Vol. 5, No. 4, Apri 11981.

63. V. V. Dolgov, B. S. Kolichev, V. V. Konstantinovich, V. V. Kulinchenko, B. V. Nikipielov, A. S. Nikiforov, Yu. P. Martinov, S. N. Osiraner, V. M. Sedov, and V. G. Shatsillo. "Development of Solidif ication and Burial Methods for Radioactive Wastes of Fuel Cycle." In Proceedings of the IAEA International Conference on Nuclear Power and Its Fuel Cycle, IAEA-CN-36/350, Salzburg, Austria, May 2-13, 1977, pp. 625-641.

64. "Special Report--United Kingdom." NUKEM Market Report on the Nuclear Fuel Cycle, October 1979.

65. N. J. Keen and A. G. Duncan. "A Review of Radioactive Waste Management Programmes in the United Kingdom." Presented at ANS Topical Meeting on the Treatment and Handling of Radioactive Wastes held in Richland, Washington, Apri1 1982.

66. F. S. Feates and J. Margat. "Disposal of High-Level Radioactive Wastes Into Crystalline Rocks." Radioactive Waste Management and Disposal, Proceedings of the First European Community Conference, Luxembourg, May $20-23,1980, p p .421-441$. 
67. D. A. V. Fischer. "Safeguards and Non-Proliferation: Geography, Prospects, Problems." International Atomic Energy Agency Bulletin, December 1981, Vol. 23, No. 4, pp. 7-10.

68. J. A. Yager. "Improving the Present International Nuclear Regime." International Cooperation in Nuclear Energy, Brookings Institute, Washington, D.C., 1981, pp. 25-41.

69. "International Nuclear Cooperation--The Initiation Needed Today." Atoms In Japan, Japan Atomic Industrial Forum, March 1982, Vol. 26, No. 3, pp. 19-22.

70. "NPT Newsletter." International Atomic Energy Agency Bulletin, December 1981, Vol. 23, No. 4, p. 30.

71. OECD Nuclear Energy Agency: Functions and Main Activities. September 1979. 


\section{DISTRIBUTION}

No. of

Copies

OFFSITE

DOE HEADQUARTERS

Office of Inspector General

U.S. Department of Energy

IG-40, Forrestal

Washington, DC 20585

ATTN: A. Walter

3 Office of International Affairs

U.S. Department of Energy

IA-22, Forrestal

Washington, DC 20585

ATTN: S. Griffith

H. Jaffe

M. McDonough

3 Office of Defense Waste and Byproducts Management

U.S. Department of Energy

DP-12, GTN

Washington, DC 20545

ATTN: G. K. Oertel

R. Scott

R. D. Walton, Jr.

Office of Nuclear Energy U.S. Department of Energy

NE-2, Forrestal

Washington, DC 20585

ATTN: T. A. Dillon

Office of Support Programs

U.S. Department of Energy

$\mathrm{NE}-4$, Forrestal

Washington, DC 20585

ATTN: S. Rosen

Office of Support Programs

U.S. Department of Energy

NE-50, GTN

Washington, DC 20545

ATTN: W. W. Henoch
No. of

Copies

Office for Breeder Reactor

Programs

U.S. Department of Energy

NE-50, GTN

Washington, DC 20545

ATTN: H. H. Rohm

Office of Converter Reactor

Development

U.S. Department of Energy

NE-10, GTN

Washington, DC 20545

ATTN: J. D. Griffith

8 Office of Terminal Waste Disposal

and Remedial Action

U.S. Department of Energy

NE-20, GTN

Washington, DC 20545

ATTN: W. W. Ballard, Jr.

D. G. Boyer

F. E. Coffman

C. R. Cooley

C. H. George

M. J. Lawrence

A. F. Perge

R. W. Ramsey, Jr.

5 Office of Spent Fuel Management and Reprocessing Systems

U.S. Department of Energy

$N E-20$, GTN

Washington, DC 20545

ATTN: R. B. Chitwood

K. A. Klein

J. A. Leary

K. 0. Loughon

W. H. McVey 
DOE HEADQUARTERS - FOREIGN

Brussels Office USEC

U.S. Department of Energy

U.S. European Communities Mission

c/o U.S. Department of State

Washington, DC 20520

ATTN: W. Ramsey

Bonn Office, American Embassy

U.S. Department of Energy

c/O U.S. Department of State

washington, DC 20520

ATTN: F. Goldner

Representative to American Embassy (Paris)

U.S. Department of Energy

APO New York 09777

ATTN: A. Friedman

Tokyo Office, American Embassy

U.S. Department of Energy

c/o U.S. Department of State

Washington, DC 20520

ATTN: B. Hill

DOE OPERATIONS OFFICE

4 Albuquerque Operations office U.S. Department of Energy

P.0. Box 5400

Albuquerque, NM 87115

ATTN: D. Campbell

R. Y. Lowrey

J. McGough

D. T. Schueler

2 Chicago Operations office

U.S. Department of Energy

9800 South Cass Avenue

Argonne, IL 60439

ATTN: R. H. Bauer, Manager

$$
\text { S. A. Mann }
$$

National Waste Program Office U.S. Department of Energy $505 \mathrm{~K}$ ing Avenue

Columbus, $\mathrm{OH} 43201$

ATTN: J. 0. Neff

Idaho Operations office

U.S. Department of Energy

550 Second Street

Idaho Falls, ID 83401

ATTN: J. B. Whitsett

Los Alamos Area Office

U.S. Department of Energy

Los Alamos, NM 87544

ATTN: K. R. Braziel, Manager

Nevada Operations Office

U.S. Department of Energy

P.0. Box 14100

Las Vegas, NV 89114

ATTN: M. E. Gates, Manager

2 0ak Ridge Operations Office

U.S. Department of Energy

P.0. Box E

0ak Ridge, TN 37830

ATTN: D. E. Large

R. Philippone

San Francisco Operations Office U.S. Department of Energy

1333 Broadway, Wells Fargo Building

Oakland, CA 94612

ATTN: L. Lanni

3 Savannah River Operations Office

U.S. Department of Energy

P.0. Box A

Aiken, SC 29801

ATTN: F. H. Allhoff

T. B. Hindman

B. Wilson

27 DOE Technical Information Center

P.0. Box 62

0ak Ridge, TN 37830 
No. of

Copies

DOE CONTRACTORS

Allied General Nuclear Services P.0. Box 847

Barnwell, SC 29812

ATTN: P. Highberger

American Nuclear Society

555 North Kensington Avenue

LaGrange Park, IL 60525

ATTN: D. G. Pettengill

2 Argonne National Laboratory

9700 South Cass Avenue

Argonne, IL 60439

ATTN: J. H. Kittel

M. J. Steindler

Argonne National Laboratory

P.0. Box 2528

Idaho Falls, ID 83401

ATTN: C. S. Abrams

3 Battelle Memorial Institute

$505 \mathrm{~K}$ ing Avenue

Columbus, $\mathrm{OH} 43201$

ATTN: F. Djahanguiri

R. J. Hall

B. Rawles

Battelle

Human Affairs Research Centers

$4000 \mathrm{NE} 41$ st Street

Seattle, WA 98105

ATTN: A. H. Schilling

Bechtel National, Inc.

P.0. Box 3965

San Francisco, CA 94119

ATTN: L. J. Jardine

International Spent Fuel Program

Boeing Engineering and Construction Company

P.0. Box 3707

Seattle, WA 98124

ATTN: E. K. Bjornerud
No. of

Copies

3 Brookhaven National Laboratory

Upton, NY 11973

ATTN: J. Bida

P. W. Levy, Physics Dept.

Research Section, Library

EG\&G Idaho, Inc.

P.0. Box 1625

Idaho Falls, ID 83415

ATTN: R. H. Beers

3 Electric Power Research Institute

P.0. Box 10412

3412 Hillview Avenue

Palo Alto, CA 94304

ATTN: C. Braun

L. Henning

R. F. Williams

4 Exxon Nuclear Idaho Company, Inc.

P.0. Box 2800, WCB-S1

1955 Fremont

Idaho Falls, ID 83401

ATTN: R. A. Brown

C. A. Hawley

A. P. Roeh

File Copy

General Atomic Company

P.0. Box 81608

San Diego, CA 92138

ATTN: M. Simnad

General Electric Company

175 Curtner Avenue

(M/C 160)

San Jose, CA 95125

ATTN: R. G. Barnes

Gulf Energy and Environmental Systems

P.0. Box 81608

San Diego, CA 92138

ATTN: L. H. Brooks 
International Energy Associates, Limited

600 New Hampshire Avenue, NW Washington, DC 20037

ATTN: H. W. Paige

Lawrence Berkeley Laboratory Berkeley, CA 94720

ATTN: P. A. Witherspoon

Lawrence Livermore National Laboratory

P.0. Box 808

Livermore, CA 94550

ATTN: F. Holzer

3 Los Alamos National Laboratory Los Alamos, NM 87544

ATTN: L. Borduin, MS 517

D. M. Kerr, Director

D. T. Oakley, MS 671

2 Mound Facility

Monsanto Research Corporation

P.0. Box 32

Miamisburg, OH 45342

ATTN: C. F. Kershner

J. R. McClain, Director

7 Oak Ridge National Laboratory

P.0. Box $X$

Oak Ridge, TN 37830

ATTN: J. 0. Blomeke

W. D. Burch

C. S. Fore

L. J. Mezga

T. H. Row

D. B. Trauger

Reference Section, Central Research Library, Room 175-B, B idg. $4500 \mathrm{~N}$

3 Rocky Flats Plant

Atomics International Division

Rockwell International

P.0. Box 464

Golden, CO 80401

ATTN: W. S. Bennett

M. A. Thompson (2)
7 Sandia Laboratory

P.0. Box 5800

Albuquerque, NM 87185

ATTN: D. R. Anderson

T. B. Cook, Jr.

J. Freedman

R. M. Jefferson

Technical Library

R. W. Lynch

W. D. Weart

2 Savannah River Laboratory

Aiken, SC 29808

ATTN: M. D. Boersma

J. L. Crandall

2 University of Arizona

Tucson, AZ 85721

ATTN: R. G. Post

M. E. Wacks

State University of New York

Cortl and, NY 13045

ATTN: R. Chaturvedi, Physics

Westinghouse Electric Corporation P.0. Box 10864

Pittsburgh, PA 15236

ATTN: J. H. Saling

West Valley Nuclear Services, Inc.

P.0. Box 191

West Valley, NY 14171

ATTN: J. L. Knabenshuh

West Valley Demonstration

Project Office

U.S. Department of Energy

P.0. Box 191

West Valley, NY 14171

ATTN: W. Hannum 
No. of

Copies

OTHER FEDERAL AGENCIES

House Interior and Insular

Committee

1327 Longworth Office B 1 dg.

Washington, DC 20515

ATTN: A. Dravo

2 U.S. House of Representatives

Committee on Science and

Technology

B-374 Rayburn Office Building

Washington, DC 20515

ATTN: J. Duggan

R. Ketchum

Office of International Activities

Environmental Protection Agency

Washington, DC 20460

ATTN: W. Grieder, A-106

2 Radiological Waste Standards Branch

Criteria and Standards Division

Environmental Protection Agency

ANR Waterside Mall East

Washington, DC 20460

ATTN: L. Batist, Chief

Office of Radiation Programs

Environmental Protection Agency

MS ANR-461

401-M S.W.

Washington, DC 20460

ATTN: G. L. Sjoblom

2 Committee on Radioactive Waste Management

National Academy of Sciences

Room JH-826

2101 Constitution Avenue, NW

Washington, DC 20418

ATTN: J. Holloway

J. Pomeroy

Radiation Safety Branch

Public Health Service

National Institutes of Health

Bethesda, MD 20205

ATTN: W. Holcomb, Bldg. 21
No. of

Copies

Division of Waste Management

U.S. Nuclear Regulatory Commission Washington, DC 20555

ATTN: Docket Control Center, MS 697-SS

Office of Inspection and Enforcement

U.S. Nuclear Regulatory Commission Washington, DC 20555

ATTN: D. M. Rohrer, MS 315 EWS

Office of International Programs

U.S. Nuclear Regulatory Commission Washington, DC 20555

ATTN: K. Burke, EWS 408

Reference Library

U.S. Nuclear Regulatory Comission Washington, DC 20555

ATTN: M. Conyngham, MS 160

Directorate of Licensing for Fuels and Materials

U.S. Nuclear Regulatory Commission 4915 St. Elmo Avenue

Bethesda, MD 20014

ATTN: Deputy Director for Fuels and Materials

U.S. Department of Interior

Bureau of Mines

Albany Research Center

1450 W. Queen Avenue

Albany, OR 97321

ATTN: R. A. Beall

U.S. Department of State

c/o U.S. Mission to IAEA/Vienna

Washington, DC 20520

ATTN: P. Brush, Counselor for

Atomic Energy Affairs

U.S. Department of State OES/ENH

Room 7820, Mail Stop 27

22nd and C Streets, NW

Washington, DC 20520

ATTN: J. Williamson 
Nuclear Technology Section Bureau of Oceanic, International and Environmental Science Affairs U.S. Department of State Washington, DC 20520

ATTN: D. Hoyle

\section{STATE AGENCIES}

Energy Resources Conservation and Development Commission

1111 Howe Avenue

Sacramento, CA 95825

ATTN: A. J. Soinski

Engineering Research and Development Authority

Empire State Plaza

Albany, NY 12223

ATTN: J. L. Larocca, Chairman

FORE IGN

Australian Embassy

1610 Massachusetts Avenue, NW Washington, DC 20036

ATTN: W. Wright, Atomic Energy Counselor

Waste Management Section Division of Nuclear Fuel Cycle

International Atomic Energy Agency

Wagramerstrasse 5, P.0. Box 100 A-1400, Vienna

Austria

ATTN: A. Hagen

Canadian Embassy

1746 Massachusetts Avenue, NW Washington, DC 20036

ATTN: J. Harrison, Science Counselor
2 Waste Management Division Whiteshell Nuclear Research Establishment

Atomic Energy of Canada, Limited Pinawa, Manitoba, ROE ILO

Canada

ATTN: D. J. Cameron

H. G. Wikjord

Power Reactor and Nuclear Fuel Development Corporation (PNC) Suite 908

2600 Virginia Avenue, NW

Washington, DC 20037

ATTN: H. Nakano, Manager

OECD Nuclear Energy Agency

38 Boulevard Suchet

F-75016 Paris

France

ATTN: J.-P. Olivier

SKBF / KBS

Box 5864

S-10248, Stockholm

Sweden

ATTN: F. Karlsson

British Embassy

3100 Massachusetts Avenue, NW

Washington, DC 20008

ATTN: J. Gaunt

ONSITE

5 DOE Richland Operations Office

R. B. Goranson

H. E. Ransom

J. J. Schreiber

M. W. Shupe

J. D. White 
No. of

Copies

3 HEDL-Westinghouse

A. G. Blasewitz

R. E. Lerch

J. D. Watrous

Joint Center for Graduate Study

J. Cooper

61 Pacific Northwest Laboratory

W. F. Bonner

T. D. Chikalla

J. M. Davidson

F. H. Dove

K. M. Harmon

A. B. Johnson, Jr.

J. A. Kelman

L. T. Lakey

J. L. MCE Iroy

R. D. Nelson

R. J. Serne
No. of

Copies

D. A. Shields (16)

W. L. Templeton

H. H. Van Tuyl

L. D. Williams

Publishing Coordination (2)

Technical Information (5)

5 Rockwell-Hanford Operations

J. L. Deichman

R. A. Deju

P. G. Lorenzini

J. H. Roecker

M. J. Smith

V. V. Ufkes, Technical Information Center

4 UNC Nuclear Industries

F. H. Bouse, Document Control

T. E. Dabrowski

A. E. Engler

W. J. Kyriazis 


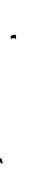

